\title{
QUALIDADE TECNOLÓGICA E ESTABILIDADE OXIDATIVA DE FARINHA DE TRIGO E FUBÁ IRRADIADOS
}

\author{
ROBERTA CLARO DA SILVA
}

\begin{abstract}
Dissertação apresentada à Escola
Superior de Agricultura "Luiz de

Queiroz", Universidade de São Paulo, para obtenção do título de Mestre em Ciências, Área de Concentração: Ciência e Tecnologia de Alimentos.
\end{abstract}

$P \mid R A C I C A B A$

Estado de São Paulo - Brasil

Julho - 2003 


\title{
QUALIDADE TECNOLÓGICA E ESTABILIDADE OXIDATIVA DE FARINHA DE TRIGO E FUBÁ IRRADIADOS
}

\author{
ROBERTA CLARO DASILVA \\ Zootecnista \\ Orientadora: Profa. Drª. MARISA AP. BISMARA REGITANO d'ARCE

Dissertação apresentada à Escola
Superior de Agricultura "Luiz de
Queiroz", Universidade de São Paulo,
para obtenção do título de Mestre em
Ciências, Área de Concentração:
Ciência e Tecnologia de Alimentos.

PIRACICABA

Estado de São Paulo - Brasil

Julho -2003 


\title{
Dados Internacionais de Catalogação na Publicação (CIP)
} DIVISÃO DE BIBLIOTECA E DOCUMENTAÇÃO - ESALQ/USP

\author{
Silva, Roberta Claro da \\ Qualidade tecnológica e estabilidade oxidativa de faninha de trigo e \\ fubá irradiados/ Roberta Claro da Silva. - - Pira cicaba, 2003. \\ 89 p. : il. \\ Dissertação (mestrado) - - Escola Superior de Agricultura Luiz de \\ Queiroz, 2003. \\ Bibliografia. \\ 1. Amazenagem de alimentos 2. Farinha de trigo 3. Fubá 4. Iradiação de \\ a limentos $\mathbf{l}$. Título
}

CDD 664.72272

"Permitida a cópia total ou parcial deste documento, desde que citada a fonte - O autor" 


\begin{abstract}
À minha mãe, Margarida Claro,

por sua força e alegria,

OFEREÇO
\end{abstract}

Aos meus sobrinhos Carol e David, com amor, DEDICO 


\section{AGRADECIMENTOS}

A Deus, pela força e proteção por toda a minha vida.

À minha orientadora, Prof â.DIE. Marisa Aparecida Bismara Regitano d'Arce, pela orientação e incentivo neste trabalho, que contribuíram muito para meu crescimento profissional e, principalmente pela grande amizade demonstrada.

À Escola Superior de Agricultura "Luiz de Queiroz" (ESALQ/USP), em especial ao Departamento de Agroindústria, Alimentos e Nutrição, pela oportunidade para a realização deste trabalho.

À Cargill Agricola S/A, pela doação da farinha de trigo e pela permissão de utilização de seus laboratórios de controle de qualidade, em especial para os funcionários Sebastião, Valderez e Irineu.

À Yoki pela doação e transporte do fubá.

À Companhia Brasileira de Esterilização, pela irradiação das matériasprimas.

À Prof à.Drª. Marta Helena Fillet Spoto, pela amizade e auxílio na elaboração da análise sensorial. 
À Prof ${ }^{a}$. DI̊ Silene Bruder Silveira Sarmento e a agrônoma Carlota Boralli Prudente dos Anjos pelo auxílio na s análises do Laboratório de Amidos e Féculas.

Aos companheiros de laboratório, Lílian, Aelson, Janaína e Selma.

Às amigas Tati, Lú, Dé, Dê e Dani, pelas boas "doses" de alegria.

Aos queridos Sove e Keethlen, pelos bons momentos.

À funcionária do Laboratório de Óleos e Gorduras do Departamento de Agroindústria, Alimentos e Nutrição, Maria Fernanda de Almeida Prado, pela amizade e auxílio técnico.

Aos funcionários Luiz e Rubens pelo auxílio na formatação das figuras.

A todos os participantes da análise sensorial.

À CAPES, pela concessão da bolsa para realização deste trabalho.

E a todas as pessoas que direta ou indiretamente colaboraram para a realização deste trabalho. 


\section{SUMÁRIO}

Página

LISTA DE FIGURAS .................................................................. ix

LISTA DE TABELAS ................................................................... xiii

RESUMO ......................................................................... Xiv

SUMMARY .......................................................................... XVi

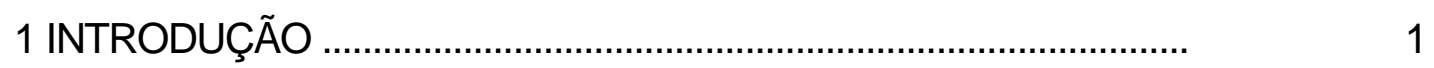

2 REVISÃO DE LITERATURA ............................................................ 4

2.1 Histórico da irradiação.................................................................... 4

2.2 Problemas no armazenamento de grãos.......................................... 7

2.3 Radiação Gama: Alternativa para a preservação de grãos e seus produtos......................................................................................... 8

2.4 Parâmetro de qualidade das farinhas.............................................. 10

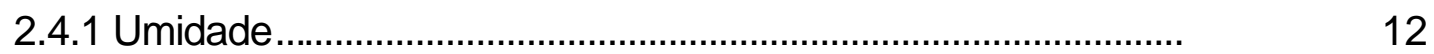

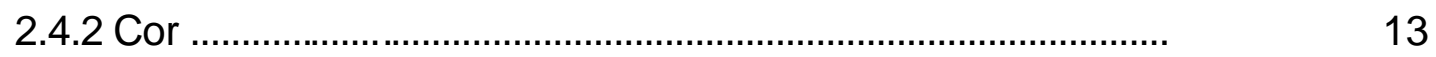

2.4.3 Análise Sensorial....................................................................... 14

2.4.4 Atividade da $\alpha$-amilase em farinha de trigo .................................. 14

2.4.5 Características reológicas da massa............................................ 14

2.4.6 Teste de panificação................................................................... 18

2.5 Alterações físico-químicas em grãos e farinhas causadas pela irradiação..................................................................................... 19

2.5.1 Alterações na fração protéica....................................................... 19

2.5.2 Alterações na fração carboidrato....................................................... 20 
2.5.3 Alterações na fração lipídica...........................................................

3 MATERIAL E MÉTODOS _.................................................................... 25



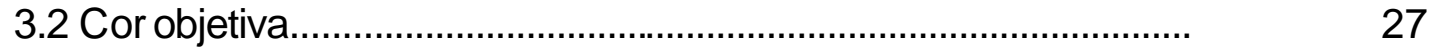

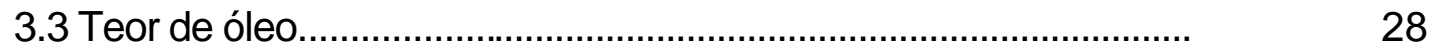

3.4 Índice de acidez

3.5 Índice de peróxido......................................................................

3.6 Absorbância específica na faixa do ultravioleta................................. $\quad 30$

3.7 Solubilidade protéica..................................................................... 30

3.8 Qualidade tecnológica da farinha de trigo........................................ $\quad 30$

3.8.1 Farinograma........................................................................

3.8.2 Alveograma ...................................................................

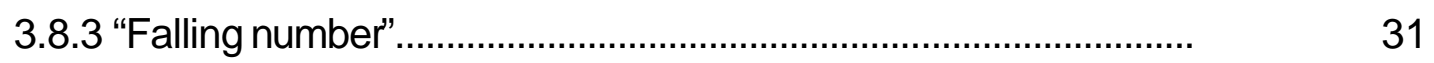

3.8.4 Teste de panificação................................................................... 31

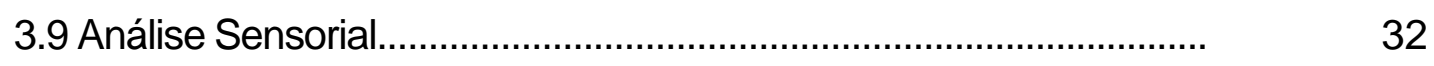

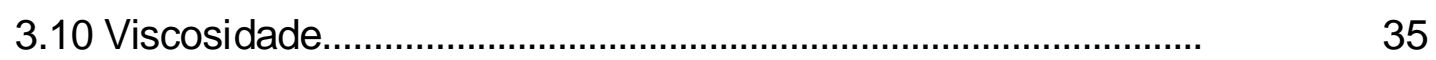

3.11 Delineamento experimental.............................................................

4 RESULTADOS E DISCUSSÃO............................................................

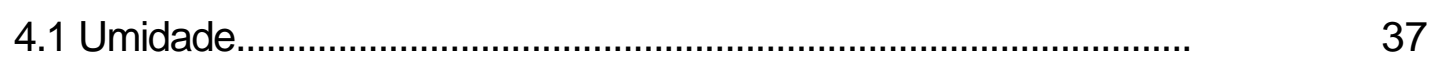

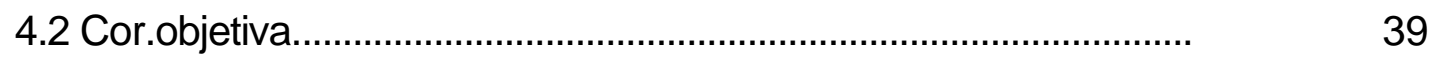

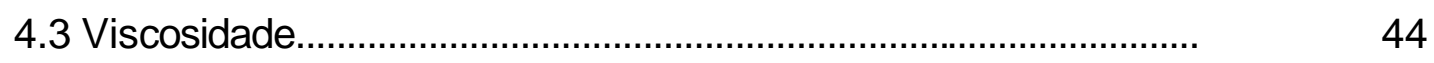





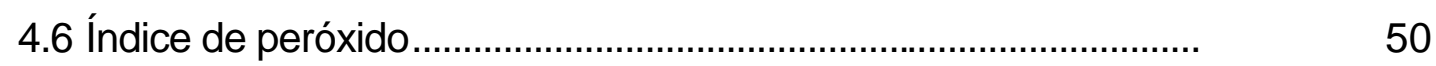

4.7 Absorbância específica na faixa do ultravioleta................................... 51

4.8 Solubilidade protéica..................................................................

4.9 Qualidade tecnológica da farinha de trigo........................................ 55

4.9.1 Farinograma.........................................................................

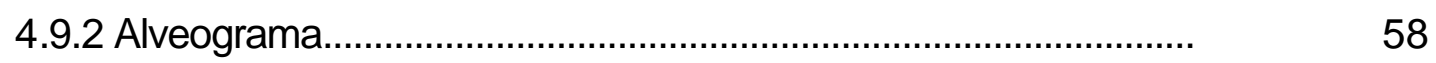

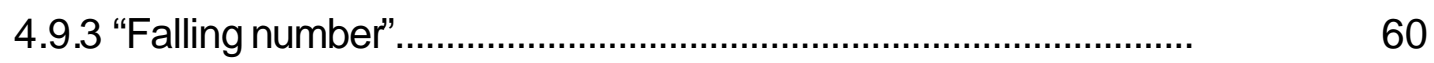


4.9.4 Teste de panificação.................................................................. 61



4.10.1 Aparência................................................................................. 67

4.10.2 Cor....................................................................................

4.10.3 Aroma.......................................................................................

5 CONCLUSÕES

REFERÊNCIAS BIBLIOGRÁFICAS................................................... 


\section{LISTA DE FIGURAS}

Página

1 Radura - símbolo utilizado em produtos irradiados.................................



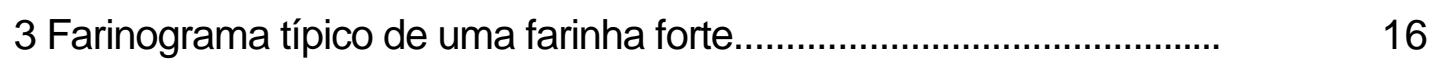

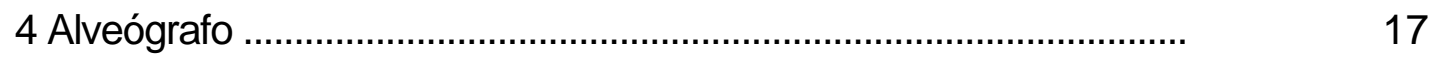

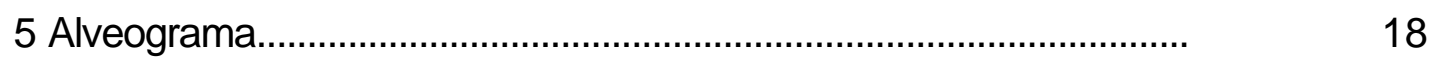

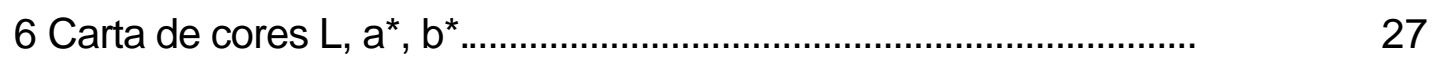

7 Ficha de avaliação sensorial das amostras de farinha de trigo e fubá.........................................................................................

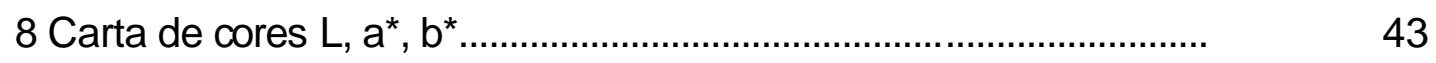

9 Parâmetros farinográficos das farinhas de trigo irradiadas e armazenadas no tempo inicial e após três meses................................. 57

10 Parâmetros alveográficos das farinhas de trigo irradiadas e armazenadas ao ambiente no tempo inicial e após três meses............... $\quad 58$

11 Relação Tenacidade/ Extensibilidade das farinhas de trigo irradiada e armazenada ao ambiente no tempo inicial e após três meses.............. $\quad 59$ 12 "Falling number" das farinhas de trigo irradiadas................................. 61

13 Parâmetros panificáveis das farinhas de trigo irradiadas.................... 64

14 Pães produzidos com farinhas de trigo irradiadas e armazenadas........ $\quad 65$

15 Freqüência das notas de aparência do fubá (controle) durante 0 armazenamento.

16 Freqüência das notas de aparência do fubá ( $3 \mathrm{kGy}$ ) durante 0 armazenamento. 
17 Freqüência das notas de aparência do fubá (4,5 kGy) durante o armazenamento.

18 Freqüência das notas de aparência do fubá (4,5 kGy) durante 0 armazenamento.

19 Freqüência das notas de aparência da farinha de trigo (controle) durante $o$ armazenamento.

20 Freqüência das notas de aparência da farinha de trigo ( $3 \mathrm{kGy}$ ) durante $o$ armazenamento.

21 Freqüência das notas de aparência da farinha de trigo (4,5 kGy) durante $o$ armazenamento.

22 Freqüência das notas de aparência da farinha de trigo (6 kGy) durante $o$ armazenamento. 69

23 Freqüência das notas de cor do fubá (controle) durante o armazenamento

24 Freqüência das notas de cor do fubá (3 kGy) durante o armazenamento

25 Freqüência das notas de cor do fubá (4,5 kGy) durante o armazenamento

26 Freqüência das notas de cor do fubá (6 kGy) durante o armazenamento.

27 Freqüência das notas de cor da farinha de trigo (controle) durante o armazenamento.

28 Freqüência das notas de cor da farinha de trigo (3 kGy) durante $o$ armazenamento.

29 Freqüência das notas de cor da farinha de trigo (4,5kGy) durante $o$ armazenamento.

30 Freqüência das notas de cor da farinha de trigo (6 kGy) durante $o$ armazenamento

31 Freqüência das notas de aroma do fubá (controle) durante $o$ armazenamento. 
32 Freqüência das notas de aroma do fubá ( 3 kGY)

durante $o$ armazenamento.

33 Freqüência das notas de aroma do fubá (4,5 kGy) durante o

armazenamento.

34 Freqüência das notas de aroma do fubá (6 kGy) durante

o armazenamento.

35 Freqüência das notas de aroma da farinha de trigo (controle) durante 0 armazenamento.

36 Freqüência das notas de aroma da farinha de trigo ( 3 kGy) durante $o$ armazenamento.

37 Freqüência das notas de aroma da farinha de trigo (4,5kGy) durante 0 armazenamento.

38 Freqüência das notas de aroma da farinha de trigo (6 kGy) durante $\mathrm{o}$ armazenamento. 


\section{LISTA DE TABELAS}

Página

1 Índice de qualidade da massa de pão.francês.

2 Esquema de análise de variância utilizada nos resultados das análises físico-químicas e sensoriais da farinha de trigo

3 Esquema de análise de variância utilizada nos resultados das análises físico-químicas e sensoriais do fubá.

4 Médias de Umidade Relativa (\%) e Temperatura (ํㅡ) dos meses de experimento (ano 2001).

5 Grau de umidade (\%) da farinha de trigo irradiada e armazenada ao ambiente.

6 Grau de umidade (\%) do fubá irradiado e armazenado ao ambiente.

7 Valores $\mathrm{L}, \mathrm{a}^{*}, \mathrm{~b}^{*}$ nas diferentes doses no primeiro mês de armazenamento em farinha de trigo

8 Valores L do fubá irradiado e armazenado ao ambiente.

9 Valores de $b^{\star}$ do fubá irradiado e armazenado a o ambiente.

10 Valores de $a^{*}$ do fubá irradiado e armazenado ao ambiente.

11 Pico de viscosidade da farinha de trigo irradiada após três meses de armazenamento.....

12 Pico de viscosidade do fubá irradiado após seis meses de armazenamento.

13 Teor de óleo (\%) da farinha de trigo irradiada e armazenada ao ambiente 
14 Teor de óleo (\%) do fubá irradiado e armazenado ao ambiente.

15 Índice de acidez (\%) das farinha de trigo irradiada e armazenada ao ambiente.

16 Índice de acidez (\%) dos fubá irradiado e armazenado ao ambiente

17 Absortividade a $232 \mathrm{~nm}$ da farinha de trigo irradiada e armazenada ao ambiente.

18 Absortividade a 270nm da farinha de trigo irradiada e armazenada ao ambiente.

19 Absortividade a $232 \mathrm{~nm}$ do fubá irradiado e armazenado ao ambiente.

20 Absortividade a 270nm do fubá irradiado e armazenado ao ambiente.

21 Solubilidade protéica (\%) da farinha de trigo irradiada e armazenada

22 Solubilidade protéica (\%) do fubá irradiado e armazenado.

23 Parâmetros farinográficos característicos de farinhas com diferentes forças.

24 Índice de qualidade da farinha tratamento controle (não irradiada) para o pão francês.

25 Índice de qualidade da farinha tratamento 3 kGy para para o pão francês.

26 Índice de qualidade da farinha tratamento 4,5 kGy para para o pão francês.

27 Índice de qualidade da farinha tratamento 6 kGy para para o pão francês.

28 Volume específico dos pães.

29 Rendimento na produção de pão francês. 


\title{
QUALIDADE TECNOLÓGICA E ESTABILIDADE OXIDATIVA DE FARINHA DE TRIGO E FUBÁ IRRADIADOS
}

\author{
Autor: ROBERTA CLARO DA SILVA \\ Orientador:Prof ${ }^{\mathrm{a}} \operatorname{Dr}^{\mathrm{a}}$ MARISA AP. BISMARA REGITANO D'ARCE
}

\section{RESUMO}

Os grãos de cereais são suscetíveis ao ataque de insetos e desenvolvimento de microorganismos durante 0 armazenamento. Pesquisas têm demonstrado a viabilidade da utilização da tecnologia de irradiação gama para a preservação conservação de grãos de cereais e seus produtos. $O$ objetivo deste trabalho foi verificar o efeito de diferentes doses de radiação gama ( $0 ; 3 ; 4,5$ e 6 kGy) em farinha de trigo e fubá sobre a estabilidade oxidativa e qualidade tecnológica. Foram avaliados os atributos sensoriais e físico-químicos, além de parâmetros tecnológicos da farinha de trigo como farinograma, alveograma, "falling number" e teste de panificação. As amostras já embaladas em fardos, foram irradiadas em um irradiador comercial e armazenadas em condições ambiente, a taxa de dose durante a irradiação foi de $7 \mathrm{kGy} / \mathrm{h}$. A qualidade oxidativa das farinhas e do fubá não foi alterada em nenhum dos tratamentos, dentro do período de validade obedecido pelos fabricantes, para os mesmos produtos não irradiados. Contudo, a acidez das farinhas foi o índice analítico que mais prontamente refletiu a ação da irradiação. Os níveis de acidez iniciais mais altos corresponderam a maiores incrementos durante o armazenamento. Os tratamentos de 4,5 e $6 \mathrm{kGy}$ tiveram efeito negativo sobre os parâmetros farinográficos, alveográficos e o "Falling 
number" da farinha de trigo alterando assim a sua qualidade tecnológica. A farinha de trigo e o fubá tiveram suas propriedades viscoelásticas afetadas em todos os tratamentos, sendo progressiva com o aumento da dose, enquanto que a qualidade sensorial não foi afetada por nenhum dos tratamentos, apesar de um odor metálico se fazer presente, sendo perceptível para alguns provadores. 


\title{
TECHNOLOGICAL PARAMETERS AND OXIDATIVE STABILITY OF IRRADIATED WHEAT AND CORN FLOUR
}

\author{
Author: ROBERTA CLARO DA SILVA \\ Adviser: Prof ${ }^{a} \operatorname{Dr}^{\mathrm{a}}$ MARISA AP. BISMARA REGITANO D'ARCE
}

\section{SUMMARY}

Cereals are susceptible to the attack of insects and microorganisms development during storage. Researches have demonstrated the viability of the use of the irradiation technology for the preservation and reduction of these losses. The objective of this work was to evaluate the effect of different irradiation doses $(0 ; 3 ; 4,5$ and $6 \mathrm{kGy})$ on wheat and corn flour oxidative stability and technological quality. Physicochemical and sensory analyses were performed on the flours. The technological parameters evaluated on the wheat flour were farinogram, alveogram, falling number, and a baking experiment. The packed samples were irradiated in a commercial irradiator and stored under ambient conditions. The oxidative quality of both flours was not affected in any of the treatments, within the commercial shelf life period guaranteed by the manufacturers for non irradiated products. However, flours acid value was the analytical parameter that reflected the irradiation effect. The higher flour initial acid values were the larger the increments with storage. The 4.5 and $6 \mathrm{kGy}$ treatments ha a negative effect on the technological quality of the wheat flour. The irradiated flours had their viscoelastic properties affected the higher the irradiation dose, the stronger the effect. None of the treatments affected the 
sensorial quality of the samples, although a metallic odor was perceived by some tasters. 


\section{INTRODUÇÃO}

O crescimento populacional é mais acelerado que a disponibilidade de alimentos, por essa razão a busca por alternativas de conservação de alimentos se faz necessária. Uma preocupação constante dos pesquisadores tem sido utilizar novas alternativas de conservação mantendo as qualidades originais dos alimentos.

As perdas quantitativas médias brasileiras estimadas pela FAO e pelo Ministério da Agricultura Pecuária e Abastecimento são aproximadamente de $10 \%$ do total produzido a cada ano. Isto representa cerca de 9,8 milhões de toneladas a cada ano. Por essa razão, cuidados constantes deves ser dados ao armazenamento de grãos e derivados. O produto armazenado tem alto valor comercial, é fruto de trabalho árduo, e as perdas, que possam ocorrer, representam, em última análise, prejuízos para toda a sociedade. Deve-se, portanto, dar a devida atenção a esta importante fase do processo produtivo, de maneira a garantir a qualidade e mi nimizar as perdas (Pereira, 1993).

Pesquisas realizadas apontam a irradiação como uma alternativa viável para a preservação de grãos e seus derivados

Os grãos de cereais são suscetíveis ao ataque de insetos e microorganismos durante o armazenamento.. A irradiação de alimentos com uma dose total de 10kGy já se demonstrou segura pelos estudiosos do comitê da World Health Organization - WHO, Food and Agriculture Organization - FAO, Organização das Nações Unidas - ONU e International Atomic Energy Agency IAEA.

As radiações ionizantes são assim chamadas porque a energia emitida é suficiente para desalojar os elétrons dos átomos e moléculas, e assim convertê- 
los em partículas carregadas eletricamente. Radiações ionizantes provenientes de raios gama, raios $X$ e procedentes de aceleradores de elétrons são utilizados industrialmente no tratamento de diversos tipos de materiais (Jay, 1992).

A irradiação tem inúmeros objetivos no processamento de alimentos, tais como conferir segurança alimentar, garantir a qualidade nutricional e prolongar a vida de prateleira dos alimentos.

Atualmente o controle de insetos é realizado pela aplicação de inseticidas e fumigantes. $O$ fumigante mais utilizado tem sido o brometo de metila, muito efetivo no controle de pragas de armazenamento, porém, sendo um composto halogenado, pode comprometer a camada de ozônio (Taylor, 1994), além de existirem suspeitas que ele seja carcinogênico. O uso deste fumigante foi avaliado cuidadosamente, e deve ser aos poucos, abandonado no Brasil. A sua utilização está permitida até o ano de 2005 (Anon.,1997) e por essa razão se espera um aumento da utilização da irradiação como alternativa de tratamento (Pszczola,1997).

O desenvolvimento de resistência dos insetos aos inseticidas é um outro motivo para o desenvolvimento de métodos alternativos para o controle das pragas. Em países altamente industrializados, este problema é menos significativo uma vez que as técnicas de armazenamento são bem avançadas. Países produtores e exportadores de grandes quantidades de cereais têm que arcar com os custos de armazenamento e levar em consideração as exigências de importação de cada país, considerando a qualidade e os métodos de desinfestação. A irradiação gama tem provado ser tecnicamente uma alternativa possível aos métodos convencionais de controle de insetos de armazenamento (Cornwell,1966; Watters, 1968; Cogburn et al.,1972).

A eficiência dos tratamentos como a irradiação depende de fatores intrínsecos como idade, sexo e estágio de desenvolvimento de cada inseto e de fatores extrínsecos como temperatura, tipo de alimento, tipo de radiação, dose e pressão de oxigênio (Corwell, 1966; Jefferies \& Banhan, 1966).

Até o presente, os custos da desinfestação por irradiação são muito 
elevados em comparação aos métodos tradicionais de preservação, mas estes poderiam ser reduzidos pela utilização de doses mínimas efetivas e pelo tratamento concomitante de outros materiais, maximizando a utilização da fonte radioativa (Tuncbilek,1997).

Mudanças químicas, físicas e bioquímicas ocorrem nos constituintes do trigo exposto àradiação gama e essas mudanças dependem da origem do trigo e da dose de radiação (Tipples \& Norris, 1965).

Tipples \& Norris (1965) verificaram que a radiação gama produziu mudanças na fração lipídica de trigo irradiado. $O$ aumento no índice de peróxido diretamente proporcional à exposição à radiação de grãos foi observado por Hanis et al. (1988), entretanto mesmo pertencendo aos constituintes de alimentos mais sensíveis à irradiação, não se observou alteração significativa nos lipídios dos cereais em dose superiores a 10 kGy.

Outros fatores ou constituintes dos cereais também sofreram modificações como diminuição do teor de amido, diminuição da viscosidade, aumento do teor de maltose, diminuição da capacidade de hidratação da proteína (Lai et al., 1959), diminuição no tempo de cozimento de cereais (Sabularse et al., 1991), diminuição do teor de antioxidantes (Hanis et al., 1998) e destruição dos pigmentos carotenóides (Tipples \& Norris, 1965).

Neste trabalho objetivourse verificar o nível de alteração provocado por diferentes doses de irradiação em farinha de trigo e fubá comparado a uma amostra controle, não irradiada, durante um período determinado de armazenamento, na tentativa de definir uma dose mínima e efetiva para a desinfestação deste tipo de produto. 


\section{REVISÃO DE LITERATURA}

\subsection{Histórico da irradiação}

O uso da irradiação em alimentos não é um estudo recente; carnes, peixes e vegetais têm sido preservados por séculos pela energia solar. Mais tarde foram utilizadas as radiações por infravermelho e as microondas como energias possíveis para o processamento de alimentos.

A idéia de utilização da radiação ionizante na preservação de alimentos surgiu quase que seguida à descoberta da radioatividade por Henri Becquerel em 1825. A sugestão do uso desta energia para destruir microrganismos patógenos e esporulados em alimentos foi publicada por um jornal médico na Alemanha no mesmo ano (MDS Nordion Science Advanced Health, 2003).

No ano de 1900, foi dada entrada em pedidos de patentes nos EUA e no Reino Unido, descrevendo a utilização da radiação para destruir microrganismos em alimentos, ressaltando a vantagem desta não utilizar nenhum aditivo químico, um conceito muito válido nos dias de hoje. Entretanto, a tecnologia não se tornou comercialmente viável, pois a única fonte de radiação ionizante não era economicamente disponível (MDS Nordion Science Advanced Health, 2003).

Outros estudos foram feitos e existem trabalhos que citam a utilização de raios $X$ para destruir insetos, ovos e larvas em fumo e eliminar a triquinose encontrada na carne suína, entretanto mais uma vez a viabilidade do processo foi dificultada pelos altos custos e a dificuldade em adquirir fontes de radiação ionizante. Nas décadas mais recentes, com o surgimento dos reatores nucleares foram descobertas outras fontes de radiação ionizante e com isto a 
irradiação se tornou um processo técnica e comercialmente viável (MDS Nordion Science Advanced Health, 2003).

Em 1950, foram iniciados os estud os sobre os efeitos da irradiação na conservação de alimentos. Nos anos 80, o FDA passou a autorizar a irradiação para o controle de insetos, para eliminar a Trichinella spiralis da carne de porco, e aumentar a vida de prateleira de algumas frutas e vegetais (FDA, 1986). $\mathrm{Na}$ mesma década também foi aprovada a irradiação para controlar insetos em grãos e farinha de trigo; para controlar insetos e microorganismos em especiarias, ervas e outros alimentos desidratados; e para prevenir o brotamento em batatas, com definição das dosagens permitidas (Newsome, 1987).

Como a temperatura atingida na irradiação é baixa, o processo é considerado "a frio", e as mudanças no sabor, cor, textura e valor nutritivo são mínimas. Efeitos nas mudanças dos valores nutritivos foram relatadas por IFT (1983), Skala et al. (1987) e Thomas (1988).

Um projeto internacional, com sede em Karlsruhe, coordenou estudos durante os anos de 1970 a 1982, quando uma junta de técnicos especialistas da WHO, FAO, da ONU e IAEA concluiu que a irradiação de qualquer alimento submetido a uma dose global de até $10 \mathrm{kGy}$ não apresentava riscos toxicológicos. Quanto à qualidade nutricional e microbiológica, o comitê considerou que nenhum problema especial ocorria, no entanto, enfatizava que dever-se-ia dar atenção para alterações significativas em relação a alimentos em particular e seu papel na dieta. Esse julgamento foi a razão do interesse de se estabelecerem os padrões do Codex Alimentarius para a segurança, a partir da documentação de alimentos irradiados, e medidas de controle e documentação do procedimento. As normas de aplicação da irradiação de alimentos estipulam que os alimentos destinados à exportação devem ser acompanhados de documentos de embarque nos quais devem estar identificados o alimento irradiado, o lote, a dose e outros detalhes do tratamento. Tais alimentos devem estar devidamente embalados e etiquetados 
para a identificação, além de ser utilizado o termo "irradiado" ou tratado por radiação ionizante, bem como estar presente o símbolo internacional para alimento irradiado (Bruhn \& Wood, 1966; ICGF/IAEA, 1991; Lusk et al.,1999; Mayer-Miebah, 1993) (Figura 1).



Figura 1 - Radura símbolo utilizado em produtos irradiados.

Atualmente 40 países possuem legislação permitindo o uso de radiação na conservação de alimentos. No Brasil as normas gerais foram estabelecidas pelo decreto lei no 72.718 de 29 de agosto de 1973, publicado no D.O.U. em 30/08/73 (D.O.U., 1973). Em 8 de março de 1985, através da portaria no 9 (D.O.U., 1985), a DINAL - Divisão Nacional de Vigilância Sanitária de Alimentos do Ministério de Saúde, em conjunto com a CNEN - Comissão Nacional de Energia Nuclear e com o INCQS - Instituto Nacional de Controle de Qualidade em Saúde, propuseram uma tabela de alimentos cuja irradiação está autorizada, a qual foi complementada pela portaria no 30 (D.O.U., 1989) da DINAL em setembro de 1989, sendo esta atualizada pela resolução RDC nำ21 (D.O.U., 2001), na qual ficou estabelecido que "qualquer alimento poderá ser tratado por irradiação desde que sejam observadas as seguintes condições: a dose mínima absorvida deve ser suficiente para alcançar a finalidade pretendida e a dose máxima absorvida deve ser inferior àquela que comprometeria as propriedades funcionais e/ au os atributos sensoriais dos alimentos". 


\subsection{Problemas no armazenamento de grãos}

Segundo Hall (1971), existem muitos fatores que podem ocasionar a deterioração dos produtos após a colheita. A composição e as características do comportamento (forças internas) dos grãos, que são variáveis, se encontram sempre submetidas à forças externas, entre elas os fatores físicos, tais como temperatura e umidade; os fatores químicos, como a disponibilidade de oxigênio; os agentes biológicos, tais como bactérias, fungos, insetos, roedores e o homem, pelos seus métodos de beneficiamento, armazenamento, transporte e desinfestação dos produtos.

Além do esforço para o aumento da produção, necessariamente, há de se incrementarem as condições de acompanhamento do armazenamento dos grãos. Uma característica positiva da maioria dos grãos é o fato de apresentarem o fenômeno de dormência, de poderem ser armazenados por períodos longos, sem perdas significativas na qualidade. Entretanto, o armazenamento prolongado só pode ser realizado quando se adotam corretamente as práticas de colheita, limpeza, secagem e combate a insetos e fungos (Lorini, 1993).

Para se obter êxito no controle das pragas do trigo armazenado, fazemse necessárias medidas de higienização e limpeza, tratamento preventivo ou curativo com inseticidas e o monitoramento da massa de grãos.

A necessidade crescente de produtos para suprir a demanda mundial de alimentos, tendo em vista o crescimento populacional, exige que a qualidade do grão colhido seja mantida, com o mínimo de perdas, até o consumo final.

Estima-se que, dos cerca de 118 milhões de toneladas de grãos que serão produzidos este ano no Brasil (IBGE, 2003), 20\% serão desperdiçadas no processo de colheita, transporte e armazenamento. As perdas por ataque de pragas durante o armazenamento poderão chegar a 10\% (Puzzi, 1989).

As pragas são as maiores causadoras de perdas físicas, além de serem responsáveis pela perda na qualidade de grãos e de subprodutos, durante as à 
comercialização e uso.

O problema tem origem em diversos fatores, dentre os quais destaca-se a inadequada estrutura armazenadora composta, em sua maioria, por armazéns graneleiros de grande capacidade estática, com sistema deficiente ou inexistente de controle de temperatura e a ausência quase total de sistema de aeração. Assim, depois de limpos e secos, os grãos são colocados nesses armazéns, onde permanecem depositados até a retirada para o uso, sem contar com um efetivo monitoramento da massa de grãos para verificar a temperatura, a umidade e a presença de insetos, situações que podem determinar grandes perdas quantitativas e qualitativas.

Outro fator que contribui para o agravamento do problema é a disponibilidade de poucos inseticidas registrados para o controle das pragas de grãos armazenados, fator este que dificulta a alternância de ingredientes ativos e gera resistência nos insetos.

Esses fatores, aliados a muitos outros, têm contribuído para que ocorram elevadas perdas de grãos, tanto em quantidade como em qualidade destes. Freqüentemente, observa-se a deterioração de grandes quantidades nos armazéns e problemas na comercialização de grãos e de farinha, devido à presença de insetos ou de restos de insetos, fatores oriundos da má conservação de grãos.

$\mathrm{Na}$ presente situação de falta de alimentos para grande parte da população brasileira que sofre com a fome e, considerando-se o oneroso esforço da sociedade em produzir grãos, não se podem admitir este desperdício (Lorini,1993).

\subsection{Radiação gama: alternativa para preservação de grãos e seus produtos}

O controle de insetos é realizado pela utilização de inseticidas e fumigantes. O fumigante mais utilizado, até então, foi o brometo de metila, muito efetivo no controle de pragas de armazenamento, porém sendo um composto halogenado, pode comprometer a camada de ozônio (Taylor,1994), 
além de existirem suspeitas que ele seja carcinogênico. A partir desta evidência, o Programa das Nações Unidas para o Meio Ambiente - UNEP, iniciou uma campanha de análise mundial que culminou com a assinatura do Protocolo de Montreal, em 1987, sobre as substâncias que destroem a camada de ozônio. Pelo acordo, os países desenvolvidos têm até 2006 para abolir o uso do brometo e os países em desenvolvimento têm até 2015 para isso. O Brasil aderiu ao cronograma estabelecido para os países desenvolvidos, tomando a importante decisão de proibir o uso do brometo de metila em 2006. A partir de $1^{\circ}$ de janeiro de 2006 será proibido o uso e a comercialização do gás, exceto em situações indispensáveis, como tratamentos quarentenários. Por esta razão se espera um aumento da utilização da irradiação como alternativa de tratamento de desinfestação (Pszczola, 1997). A busca do consumidor por produtos livres de resíduos químicos também favorece a utilização deste processo para a eliminação de pragas de armazenamento (Aldryhim \& Adam, 1999).

Autores como Cornwell (1966), Watters (1968), Wiendl (1969) e Cogburn et al. (1972) estudaram a utilização da irradiação como alternativa para a desinfestação de grãos e derivados e comprovaram a sua eficácia. Estudos mais recentes concordam com os anteriores quanto à eficácia deste método de conservação de grãos. Tuncbilek \& Kansu (1995) estudaram os efeitos da irradiação na sobrevivência de Tribolium confusum em trigo; em um outro estudo, Tuncbilek (1997) constatou a eficiência do método para a erradicação de Oryzaephilus surinamesis, Aldryhim \& Adam (1999) avaliaram a eficácia da irradiação na sobrevivência do Sithophilus granarius, todos insetos que atacam grãos armazenados.

O desenvolvimento de resistência dos insetos aos inseticidas pelos insetos é um outro motivo para o desenvolvimento de métodos alternativos para o controle de pestes. Em países altamente industrializados, este problema é menos significativo uma vez que as técnicas de armazenamento são bem avançadas. Países produtores e exportadores de grandes quantidades de 
cereais têm que arcar com os custos de armazenamento e levar em consideração as exigências de importação de cada país, considerando a qualidade e os métodos de desinfestação.

Enquanto em práticas comuns de desinfestação, os tratamentos químicos levam normalmente à letalidade em 24 horas, a desinfestação por irradiação não causa letalidade num curto período de tempo, a menos que se utilizem altas doses como na faixa de 3-5 kGy (Urbain, 1986).

O uso de pesticidas químicos é o principal método de controle de perdas causadas por insetos durante o armazenamento. A desinfestação por irradiação pode ser uma alternativa aos tratamentos químicos. A eficiência dos tratamentos com irradiação depende de fatores intrínsecos como idade, sexo e estágio de cada inseto, e de fatores extrínsecos, como temperatura, tipo de alimento, tipo de radiação, dose e pressão de oxigênio (Corwell, 1966; Jefferies \& Banhan, 1966).

Até o presente, os custos de desinfestação por irradiação são altamente elevados em comparação aos métodos tradicionais de preservação, mas estes poderiam ser reduzidos pela utilização de doses mínimas efetivas e pelo tratamento de outros materiais, maximizando a utilização da fonte (Tuncbilek,1997).

\subsection{Parâmetros de qualidade das farinhas}

A legislação brasileira define como "farinha" o produto obtido pela moagem da parte comestível de vegetais, podendo sofrer previamente processos tecnológicos adequados. O produto é designado "farinha", æaguido do nome do vegetal de origem, como por exemplo, "farinha de mandioca", "farinha de arroz", "farinha de banana", podendo ser classificada de acordo com as suas características, em:

a) farinha simples - produto obtido da moagem ou raladura - dos grãos, rizomas, frutos ou tubérculos de uma só espécie vegetal. 
b) farinha mista - produto obtido pela mistura de farinhas de diferentes espécies vegetais.

As farinhas devem ser fabricadas a partir de matérias primas e limpas, isentas de matéria terrosa e parasitos. Não podem estar úmidas, fermentadas ou rançosas (ANVISA, 2001).

As radiações ionizantes, raios gama e elétrons acelerados têm alto poder de penetração, permitindo tratamentos homogêneos e ausência de resíduos tóxicos, além de evitar a elevação de temperatura dos produtos em níveis prejudiciais durante o tratamento (Martinelli Filho, 1987). Com o uso de um processo de conservação como o da radiação gama para controlar as contaminações, obtêm-se aumentos na durabilidade, menores perdas, maior rendimento, melhor qualidade, propiciando organização e padronização dos produtos, tornando viável a mecanização na indústria de panificação. Isso conduzindo à redução no tempo de processamento, maior eficiência, higiene e economia final (Pence, 1968; Emulzint, 1985).

A ação das radiações ionizantes é conseqüência dos efeitos primários e secundários sobre as moléculas de água, dos alimentos e organismos contaminantes, ionizando-as, e dos íons formados recombinando ou interagindo com outros componentes (Dias Filho, 1988).

Segundo Urbain (1986), a irradiação pode ser utilizada para beneficiar os produtos de panificação através de dois caminhos:

1) irradiação dos ingredientes $e$

2) irradiação do produto final de panificação

Os objetivos podem ser a radurização ou desinfestação. A radurização de ingredientes pode ser direcionada à inativação de bactérias e fungos. $A$ desinfestação é a eliminação de pragas, tais como traças, carunchos e ácaros.

Doses de 0,75 kGy aplicadas em farinha de trigo que foram posteriormente usadas para produção de pães promoveram um aumento de cerca de $50 \%$ na sua vida útil, mesmo àtemperatura de $30^{\circ} \mathrm{C}$ (Urbain, 1986).

Quando se iniciaram as pesquisas com desinfestação de grãos, muitos 
trabalhos foram feitos estabelecendo a dose mínima letal e de esterilização para várias espécies de pragas de armazenamento, mas poucas pesquisas foram realizadas avaliando o conteúdo nutricional dos alimentos após a irradiação (Shipp, 1966). Alguns dos poucos trabalhos que avaliaram a alteração físico-química e nutricional do grão e da farinha de trigo irradiado foram de Campa et al. (1966) e Lai et al. (1959). Köksel et al. (1998) descreveram os efeitos da irradiação gama nas proteínas do glúten do trigo, enquanto Tipples \& Norris (1965) estudaram os efeitos na fração lipídica do grão e farinha de trigo. Zaied et al. publicaram, em 1996, um trabalho com as características químicas e tecnológicas de pães preparados com farinha de trigo irradiada. Mais recentemente Marathe (2002) apresentou resultados em um estudo de vida útil de farinha de trigo irradiada. Quanto à farinha de milho ou fubá, nenhum trabalho foi realizado avaliando os efeitos da irradiação na sua qualidade.

\subsubsection{Umidade}

O grau de umidade da farinha deve ser controlado não só por motivos econômicos, uma vez que as farinhas são comercializadas em base úmida, mas também por sua importância na conservação e processamento.

A Portaria nْ354 - SVS (Secretaria de Vigilância Sanitária)/MS (Ministério da Saúde), de 18/07/96, cita que o grau de umidade do produto deverá ser regulado pelas Boas Práticas de Fabricação, não podendo exceder $15 \% \mathrm{~m} / \mathrm{m}$.

Para se obterem bons resultados, o conteúdo de água e deve estar ao redor de $13 \%$. As farinhas com umidade acima de 14\% têm tendência a formar grumos e não fluem uniformemente. Em processos contínuos, a proporção constante entre farinha e água é essencial para a uniformidade do fluxo e movimentação na indústria. Variações nesta proporção podem causar problemas durante a extrusão e secagem comprometendo a qualidade do produto final (Ciacco \& Chang, 1982). 
O método mais preciso para a determinação da umidade em farinha é o gravimétrico. Consiste em aquecer em estufa a $105^{\circ} \mathrm{C}$ uma amostra de farinha com peso conhecido em recipiente seco por aproximadamente 24 horas. Com a diferença dos pesos da amostra úmida e seca, calcula-se a porcentagem de água (Pregnolatto, 1985).

Ciacco \& Chang (1982) citam o método de determinação indireta da umidade de farinhas baseado na sua condutividade elétrica, que é diretamente proporcional àquantidade de água da amostra.

O conteúdo de água da farinha tem enorme importância econômica, por ser inversamente proporcional à quantidade de matéria seca, além de, durante a estocagem, ser o principal fator que governa a conservação da sua qualidade.

\subsubsection{Cor}

A farinha de trigo pode apresentar diferentes colorações, dependendo do tamanho das partículas, do conteúdo de pigmentos carotenóides e da atividade da enzima lipoxigenase. As partículas finas, por refletirem uma maior quantidade de luz, geralmente apresentam uma aparência mais branca que as partículas mais grossas. Os pigmentos carotenóides são responsáveis pela coloração amarelada da farinha. Já a enzima lipoxigenase oxida os pigmentos da farinha (Ciacco \& Chang, 1982).

A farinha de trigo deve apresentar cor branca, com tons leves de amarelo, marrom ou cinza, conforme o trigo de origem (Portaria ni 354, de 18/08/96 Ministério da Saúde - Secretaria de Vigilância Sanitária).

A cor da farinha está diretamente relacionada com o seu grau de qualidade. Quanto mais branca for a farinha de trigo, por exemplo, maior será a sua qualidade e mais alta sua classificação.

Kang et al. (1999) avaliaram através de Colorímetro Minolta, os efeitos da irradiação sobre os parâmetros de cor $L, a^{*}, b^{*}$ em amidos modificados. Autores como Lai et al. (1959), Corwell (1966); Yen et al. (1956) e Marathe et al. (2002) observaram alterações na cor de farinha irradiada 


\subsubsection{Análise sensorial}

O odor deve ser característico de um material farináceo que provém de trigo ou milho recém colhido. Náo é raro possuir um odor de "velho", devido à moagem de grão de armazenado por muito tempo e tratado com substâncias para assegurar a sua conservação, mas esse odor desaparece com o processamento. Se o grão for armazenado com umidade superior à crítica, a farinha apresenta um odor desagradável, devido àalteração da matéria graxa e protéica, prejudicando a qualidade do produto final. Quanto ao sabor, poderão ocorrer as mesmas alterações do odor (Leitão et al., 1990).

\subsubsection{Atividade da $\alpha$-amilase em farinha de trigo}

A ocorrência de chuvas no campo após o amadurecimento do trigo e antes da colheita pode causar a germinação dos grãos e, conseqüentemente, a deterioração em níveis que comprometem sua utilização industrial. Mesmo que a germinação não seja aparente, o teor da enzima $\alpha$-amilase pode ser alto e provocar a degradação do amido durante o processo de fabricação do pão. Por outro lado, a baixa atividade da $\alpha$-amilase também afeta negativamente a panificação (Moss et al.,1972).

O "Falling number" também conhecido como método do índice de queda, é o método mais rápido e adequado para determinar a atividade da $\alpha$-amilase (Pizzinatto, 1997). Normalmente a farinha de trigo boa para a panificação tem um valor de "Falling number" entre 200 e 300.

\subsubsection{Características reológicas da massa}

Os testes físicos da massa são usados para avaliar o potencial de panificação, ou seja, a força e o desempenho da farinha sob condições mecanizadas. Tal avaliação tem assumido considerável importância como resultado do advento dos misturadores de alta velocidade e processos contínuos (Oliver \& Allen, 1992) 
Há dois objetivos principais nestes tipos de testes de farinhas: o primeiro deles é acompanhar e controlar os parâmetros específicos da farinha e o segundo, predizer o comportamento da massa em uma padaria convencional. $O$ farinógrafo e o extensógrafo podem ser usados como instrumentos de controle de processo com sucesso. A farinografia é um dos mais complexos e sensíveis testes de avaliação e controle de qualidade da farinha de trigo (Oliver \& Allen, 1992).

O farinógrafo é um aparelho que simula o processo de mistura, medindo e registrando a resistência da massa durante os sucessivos estágios de seu desenvolvimento (Figura 2). Assim tem-se o comportamento da massa durante a mistura e a sobremistura (mistura excessiva).

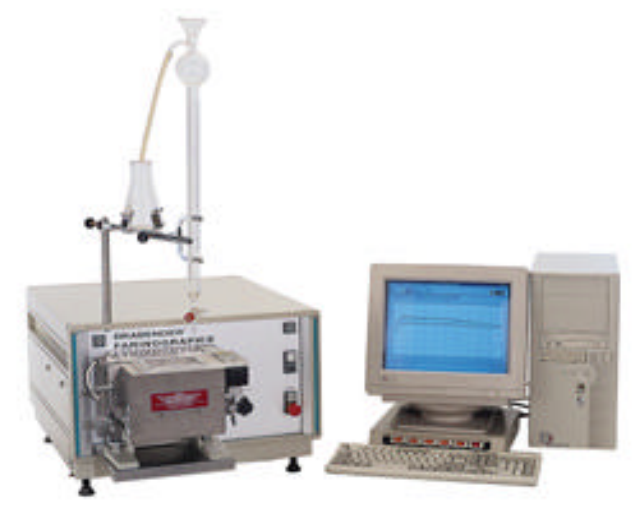

Figura 2- Farinógrafo.

A partir deste aparelho obtém-se o valor A, de absorção de água, que é a quantidade de água requerida para que a massa atinja a consistência ótima, o tempo de desenvolvimento da massa (TDM), que é o tempo necessário para que a massa atinja o máximo de sua consistência; a estabilidade (E) ou o tempo que a massa permanece consistente durante o batimento (500UF) e o índice de tolerância àmistura (ITM) que é tempo decorrido após um intervalo de cinco minutos do ponto de consistência máxima da massa, para sua perda total.

Todos esse valores podem ser determinados no gráfico resultante do 
teste conforme apresentado na Figura 3, onde o B representa a tempode desenvolvimento da massa (TDM), o C representa o índice de tolerância à mistura (ITM), o E a estabilidade (E).

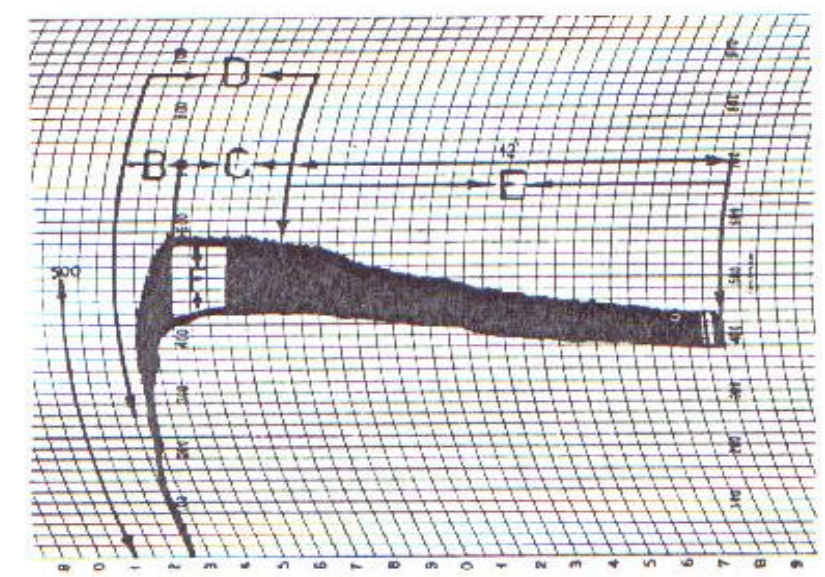

Figura 3 - Farinograma típico de uma farinha forte.

O extensógrafo foi desenvolvido para complementar as informações fornecidas pelo farinógrafo, medindo e registrando a resistência da massa à extensão, enquanto ela é esticada àvelocidade constante.

Os parâmetros avaliados são $\mathbf{R}$, que representa a resistência que a massa apresenta à extensão após 5 minutos do início do estiramento; RM, que representa a resistência máxima da massa à extensão e $\mathbf{E}$, de extensibilidade, que é quanto a massa pode ser esticada sem que se rompa.

Entretanto, Pizzinatto (1997) e Germani e colaboradores (1997) sugeriram o uso do alveógrafo, em lugar do extensógrafo, com a vantagem de o primeiro estender a massa em duas direções, portanto, uma extensão biaxial, enquanto o extensógrafo promove apenas uma extensão uniaxial.

Esse tipo de extensão biaxial está associada à expansão da célula de gás (alvéolo) durante o crescimento da massa. Assim, a deformação da massa, durante o teste do alveógrafo assemelha-se muito àdeformação que ocorre na massa durante a fermentação e crescimento de forno (Figura 4). 


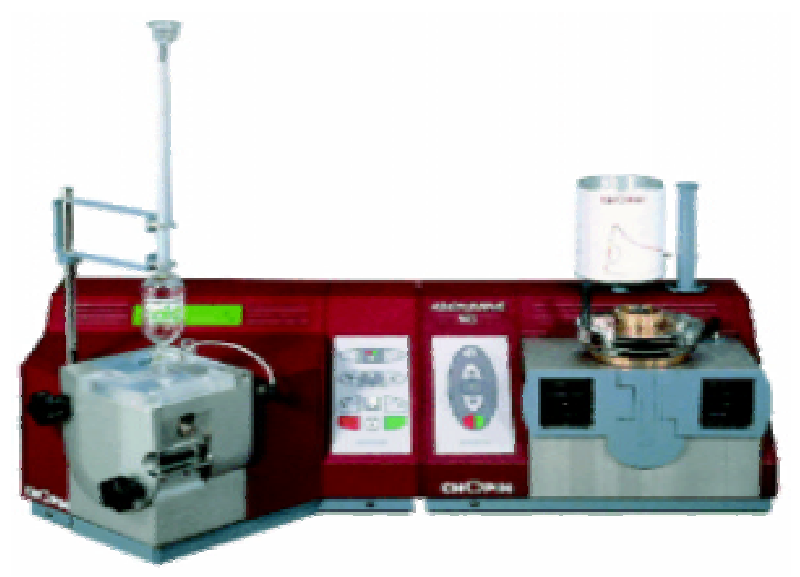

Figura 4 - Alveógrafo.

O alveógrafo registra as curvas de extensão, sob pressão de um volume de ar determinado, da massa teste tensionada até a quebra.

A hidratação realizada é constante, mesmo que a capacidade de absorção de água da farinha testada varie, ou seja, a massa é preparada com uma quantidade fixa de água, não importando sua consistência. Essa condição do método de teste tem sido objeto de crítica em muitos estudos.

Os parâmetros avaliados no alveograma (Figura 5) são a tenacidade $(\boldsymbol{P})$, que é a resistência que a massa oferece ao estiramento (como uma bexiga em processo de enchimento); a extensibilidade (L), capacidade de estiramento da massa sem que ela se rompa; a configuração de equilíbrio da curva (P/L) e 0 trabalho de deformação ou força (W) que caracteriza a força da farinha representada pelo trabalho de deformação de um grama de massa obtida em condições definidas. 


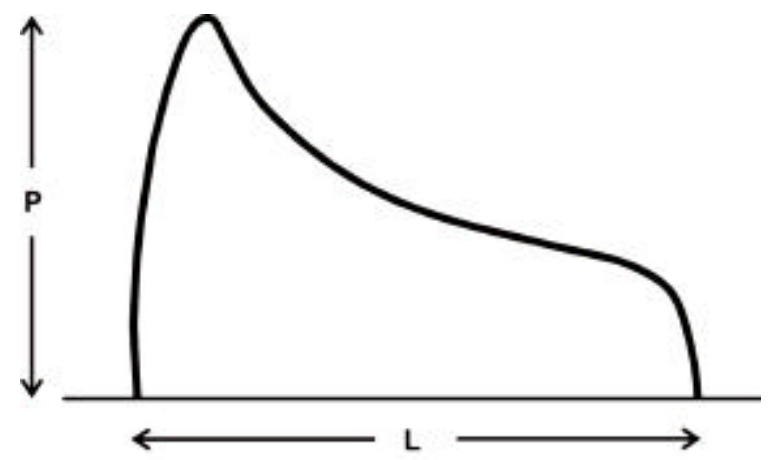

Figura 5 - Alveograma.

\subsubsection{Teste de panificação}

Hartung et al. (1973) aplicaram doses baixas de radiação gama em farinha de trigo e em pães frescos fatiados, objetivando o aumento da vida de prateleira dos pães para uso em vôos espaciais tripulados. Os tipos de pães frescos - branco e escuro - foram definidos pelo setor competente de alimentos da NASA. Os mesmos foram preparados com farinha irradiada com 0,5 kGy e não irradiada, fatiados, congelados. Em seguida, todos os pães receberam uma dose de $0,5 \mathrm{kGy}$ e foram armazenados a $21-25^{\circ} \mathrm{C}$. Notou-se que a radiação gama reduziu o conteúdo microbiano da farinha, mas o efeito foi mais significativo no pão. A irradiação dupla da farinha e do pão promoveu uma maior inibição de fungos.

Farkas \& Andrassy (1981) irradiaram farinha de trigo com doses de 0,75 e 1,5 kGy, que ficaram armazenadas em sala àtemperatura ambiente após a irradiação. Pães foram fabricados entre o quinto e o sexagésimo quarto dia de estocagem pós-irradiação. A vida de prateleira de pães preparados com farinha irradiada foi $50 \%$ maior que a do controle, ambos em mantidos a de $30^{\circ} \mathrm{C}$. Os mesmos resultados foram obtidos quando as amostras de farinha de trigo foram armazenadas por dois meses após a irradiação e, posteriormente, processadas a pães. 


\subsection{Alterações físico-químicas em grãos e farinhas causadas pela irradiação}

Em cereais não são apenas as características sensoriais, como o sabor e a cor, as afetadas pelo processo e irradiação, mas também algumas das propriedades funcionais podem ser alteradas por esse processo. A farinha de trigo, por exemplo, pode ter suas características reológicas alteradas, causando danos no momento da fermentação do pão, que é dependente da presença de amidos e componentes protéicos específicos. Sendo assim, quando a dose afeta a funcionalidade do produto, ela passa a ser inviável para essa utilização (Urbain, 1986).

Além do fato de preservar, alguns trabalhos indicam que a irradiação gama causa uma mudança na qualidade dos cereais, podendo ter efeitos mo resultado da panificação (Lai et al. 1959; $\mathrm{Ng}$ et al., 1989).

O potencial promissor de alimentos irradiados para a preservação e outros usos tem sido estimulado de longa data por uma extensa literatura (Bauman et al., 1957; Brownell et al, 1955; Yen et al., 1956).

Mudanças químicas, físicas e bioquímicas ocorrem nos constituintes do trigo exposto à radiação gama, e essas mudanças dependem da origem do trigo e da dose de radiação (Tipples \& Norris, 1965).

\subsubsection{Alterações nafração protéica}

A proteína contida em cereais é significativa para o seu valor nutricional, e, no caso de alguns alimentos como o arroz e o trigo, também importante para as características funcionais. Altas doses de irradiação (30kGy) não afetam o conteúdo de proteína. Contudo pode ocorrer aumento do teor de aminoácidos livres. Pequenos incrementos nos teores de isoleucina, tirosina, valina e alanina foram observados em trigo irradiados com doses de 10kGy (Urbain, 1986).

Hafez et d. (1985) estudaram os efeitos da irradiação nas proteínas e aminoácidos de soja, tendo verificado um decréscimo na solubilidade da 
proteína.

Em farinhas irradiadas as proteínas tem maior solubilidade das frações albumina, gliadina e glutenina (Tipples \& Norris, 1965).

Alguns autores sugerem que a radiação gama de trigo resulta em degradação molecular de proteínas (Milner,1961; Srinivas et al.,1972), ao passo que outros relatam que a solubilidade da proteína do trigo e da farinha não foi afetada pela irradiação (MacArthur \& D'Appolonia,1983; Fifield et al., 1967).

A irradiação desses cereais até a dose de 10kGy não causou nenhuma redução no teor de aminoácidos livres. Uma dose de 25kGy destruiu cerca de $39 \%$ da metionina em farelo de trigo, $26 \%$ em grãos de milho e $31 \%$ em flocos de aveia. Além disso, as perdas em torno de $33 \%$ de cisteína também foram observadas em milho, não ocorrendo, porém, nos outros cereais. Dados na literatura indicam que não há destruição de aminoácidos em vários tipos de alimentos até uma dose de 70kGy (Ito \& lizuka 1979; Van Kooij, 1979; Eggum, 1979).

\subsubsection{Alterações na fração carboidrato}

Segundo El- Dash et al. (1982) e Pomeranz (1987), as características internas e externas dos produtos de panificação dependem da qualidade, quantidade e tipos de ingredientes da b́rmula, tipo de fermentação, tempo e temperatura de cozimentos e práticas complementares de processamento. Dentre os ingredientes básicos, o fundamental é a farinha, que pode derivar de vários cereais, especialmente de trigo, sua principal fonte de proteínas, contendo também enzimas, aminoácidos, vitaminas, principalmente do complexo B, minerais, cálcio e ferro, e carboidratos. No caso da farinha de trigo, o carboidrato mais importante é o amido, polissacarídeo responsável, juntamente com o glúten, pelo "corpo" dos produtos de panificação.

Estudos foram realizados sobre os efeitos da radiação ionizante no amido do trigo (Lai et al. 1959; Milner, 1961) e no endosperma da aveia (Faust \& Massey, 1966). A radiação gama é capaz de hidrolisar as ligações químicas, 
quebrando grandes moléculas de amido em pequenos fragmentos de dextrinas que podem ser alteradas eletricamente em radicais livres. Estas mudanças podem afetar propriedades físicas e reológicas de alimentos irradiados, resultando em uma diminuição na solubilidade do amido (Deschreider, 1959), em um decréscimo no poder de geleificação (Tollier Guilbot, 1970) e em um decréscimo considerável da viscosidade da pasta de amido (Valil et al., 1973). Segundo Roushdi et al. (1983), a iradiação tende a acentuar a perda da viscosidade com o armazenamento. Kang et al. (1999) avaliaram amidos modificados irradiados e observaram uma brusca queda na viscosidade.

O amido constitui cerca de $90 \%$ dos carboidratos presentes. Altas doses de irradiação provocam alterações nos carboidratos do trigo. $O$ teor de amido diminui e o total de açúcares redutores aumenta. O teor de umidade do grão no momento da irradiação afeta o grau e a intensidade das alterações nos carboidratos. Altos teores de maltose são produzidos com umidades mais altas no grão do trigo. Provavelmente a irradiação induz a despolimerização do amido em presença de alta umidade (Ananthaswamy,1970).

Como método para produzir amidos modificados, a irradiação gama produziu radicais livres nas moléculas de amido, afetando seu tamanho e sua estrutura (Raffi et al., 1980; Ciesla et al. 1991; Grant \& D'Appolonia, 1991; Saburlarse et al., 1991). Kang et al. (1999) utilizaram doses de radiação gama de 0, 10, 30 e 50 kGy para a produção de amidos modificados.

Existe uma evidência considerável de que o aumento da dose de irradiação resulta num aumento dos produtos da radiólise, Berger \& Sain Lébe (1969) detectaram a produção de malonaldeido, um produto da radiólise, em amidos irradiados. Pequenas doses de raios gama de 20.000 a 150.000 rad (0,2 -1,5 kGy) determinaram um máximo nas curvas de viscosidade do amido, das substâncias precipitáveis por eletrodiálise, na solubilidade de gliadinas e o índice de queda, também conhecido por "Falling Number", explicando assim a melhoria nas qualidades de panificação que alguns autores observaram em farinhas irradiadas com baixas doses de raios gama (Lai et al., 1959; Tipples \& 
Norris, 1965).

\subsubsection{Alterações na fração lipídica}

As principais alterações da irradiação na fração lipídica são a formação de peróxidos (Nawar,1972) e de componentes voláteis (Merritt, 1972) que são os principais responsáveis pela rancidez e "off-flavors" em alimentos irradiados Entretanto, para que ocorra degradação lipídica em cereais, as doses de irradiação devem ser bem altas (Tipples \& Norris, 1965).

Chung et al. (1967), estudando as alterações causadas pela irradiação na fração lipídica da farinha de trigo, não encontraram efeitos significativos.

Byun et al. (1996), investigando as propriedades físico-químicas do óleo extraído de soja irradiada, também não encontraram grandes alterações quanto àoxidação.

Mesmo com altas doses de irradiação, da ordem de 100 kGy, poucas alterações ocorreram nos triglicerídeos, galactolipídeos e fosfolipídeos, que se refletiram no maior teor de ácidos graxos livres, monoglicerídeos e diglicerídeos. Com doses entre 0,1 e 1,75 kGy, Urbain (1986) não observou alteração. Contudo para Tipples e Norris (1965) o índice de peróxido respondeu positivamente æ̀ doses de irradiação. Eles trabalharam com farinhas provenientes de trigo irradiado, com doses de 0, 1, 10, 50, 100 kGy, armazenadas durante 6 meses e observaram um aumento do índice de peróxido paralelo ao aumento da dose de irradiação. $\mathrm{O}$ aumento do índice de peróxido foi associado a um odor não característico de farinha.

Hannis \& Mnukova (1985) verificaram que baixas doses de irradiação, até 10 kGy, não causaram nenhuma alteração nos lipídios dos cereais. A aplicação de altas doses pode levar a algumas mudanças em função do tipo e composição do lipídio, a presença de antioxidantes, composição do cereal irradiado, condições de irradiação, etc. (Delincee, 1983, Nawar, 1983).

O teor de carotenóides da fração lipídica das farinhas diminuiu sob a ação da radiação e desapareceu quando as doses chegaram a 4 Mrad (40 kGy) (Tipples \& Norris, 1965). 
Tipples \& Norris (1965) observaram que a fração lipídica de farinhas irradiada oxidava menos em 6 meses de armazenamento que farinhas não irradiadas. A rancidez é definida como fator adverso de qualidade, produz sabor e aroma indesejáveis e altera as propriedades funcionais de forma inaceitável.

As alterações nos lipídios ocorrem por reações entre ácidos graxos insaturados e o oxigênio, catalisado ou não por enzimas, produzindo hidroperóxidos. Estes são degradados em compostos voláteis e não voláteis, que normalmente resultam em sabores rançosos típicos (Gutkoski \& Pedó, 2000). Os triglicerídeos do grão são passíveis de sofrerem quebra pelas lipases a ácidos graxos livres e glicerol durante 0 armazenamento, especialmente quando a temperatura e a umidade estão altas e assim favorecer a deterioração. Este tipo de alteração é bastante acelerado pelo crescimento fúngico devido à atividade lipolítica alta dos fungos. A hidrólise lipídica ocorre muito mais rapidamente do que a de proteínas ou carboidratos em grãos estocados. Por esta razão o teor de ácidos graxos livres é usado como um índice sensível de deterioração incipiente do grão (Tipples \& Norris,1965).

Assim, além do sabor desagradável, ocorre o aumento da acidez, susceptibilidade dos ácidos graxos æ̀ reações de oxidação e alterações das propriedades funcionais (Gutkoski \& Pedó, 2000). Tipples \& Norris (1965) relataram que o sabor indesejável em alimentos irradiados apresentou uma semelhança com o que era encontrado na rancidez oxidativa. Lai et al. (1959) verificaram que o trigo irradiado apresentou um forte odor, o qual foi mais intenso com altos teores de irradiação e persistiu quando o trigo foi moído.

Grãos contêm antioxidantes relativamente ativos e o óleo nele contido está bastante protegido contra os efeitos do oxigênio do ar. Por estas razões, o desenvolvimento de ranço oxidativo raramente é um problema sério no armazenamento de grãos, sendo um problema com óleos e produtos do esmagamento de grãos oleaginosos. A farinha de trigo integral só pode ser armazenada por um tempo curto, visto que ela se oxida, independentemente do seu grau de umidade (Zeleny, 1954). 
A deterioração do trigo durante 0 armazenamento é geralmente acompanhada por menores rendimentos de lipídeos extraídos com éter de petróleo (Pomeranz et al., 1956). Estes mesmos autores verificaram uma diminuição de $20 \%$ no teor de lipídeos livres com o aumento de 20 vezes na contagem de fungos. Daftary \& Pomeranz (1965) estudaram as mudanças nos lipídeos de trigo duro e macio armazenado com elevados teores de umidade e altas temperaturas. Um aumento na contagem de fungos de 1.000 para 2.000.000 por grama foi acompanhado por 40\% de redução no teor de lipídeos totais. O teor de lipídeos apolares diminuiu $25 \%$ em trigo danificado que continha apenas um terço dos lipídeos polares que o trigo inteiro e sadio. A deterioração foi acompanhada pelo rápido desaparecimento de glicolipídeos e fosfolipídeos. A quebra dos lipídeos polares foi mais rápida e intensa do que a formação de ácidos graxos livres ou o desaparecimento dos triglicerídeos. A deterioração dos grãos foi acompanhada pela formação de, pelo menos, quatro compostos que apresentaram fluorescência sob luz ultravioleta. Quando a farinha de trigo, contendo $14,7 \%$ de umidade, foi armazenada em sacos de polietileno à temperatura ambiente por seis meses, grumos foram formados, houve um escurecimento considerável e um odor de bolor (Pomeranz et al., 1968). Estas mudanças foram acompanhadas por uma redução substancial dos lipídeos ligados e uma quebra quase completa dos lipídeos livres da farinha. Os padrões de eletroforese em gel de amido indicaram que, sob as condições de armazenamento usadas, as proteínas sofreram apenas pequenas mudanças.

Hanis et al. (1988) não encontraram grandes aumentos nos índices de acidez nos lipídios dos cereais de milho, trigo e aveia irradiada. $O$ índice de peróxido aumentou proporcionalmente em relação à dose de irradiação. $O$ aumento do índice de peróxido não foi acompanhado pelo desprendimento de odores desagradáveis, freqüentes em valores de peróxidos acima $100 \mathrm{meq} / \mathrm{kg}$ e que já foram reportados anteriormente (Fullerton et al., 1982; Hanis \& Mnukova,1985). 


\section{MATERIAL E MÉTODOS}

O presente projeto foi desenvolvido no Laboratório de Óleos e Gorduras do Departamento de Agroindústria, Alimentos e Nutrição da ESALQUSP.

As amostras de farinha de trigo e fubá foram obtidas de empresas do ramo e a irradiação foi realizada pela Companhia Brasileira de Esterilização (CBE).

A farinha de trigo foi embalada em sacos de polietileno de $1 \mathrm{~kg}$, sendo posteriormente embalada em fardos de papel Kraft com quatro pacotes cada fardo, num total de $80 \mathrm{~kg}$ de farinha de trigo, para o ensaio de armazenamento. O mesmo procedimento foi realizado com o fubá, entretanto, como a forma de comercialização dessa farinha é em sacos de polietileno de 500 gramas, o total embalado foi de $32 \mathrm{~kg}$.

De acordo com a literatura, está comprovada a eficiência da irradiação para a desinfestação de grãos e seus produtos, com doses que normalmente são de 0,1 até 1,5 kGy. Entretanto como o objetivo deste trabalho foi avaliar os efeitos da irradiação na qualidade tecnológica e a estabilidade oxidativa destas farinhas, as doses aplicadas foram superiores \$े normalmente utilizadas, de 3 , 4,5 e 6 kGy.

Após a irradiação, as amostras de farinha de trigo e fubá foram armazenadas à temperatura ambiente por três e seis meses, respectivamente, que correspondem ao prazo de validade dado por cada fabricante para produtos semelhantes não irradiados.

No primeiro mês de armazenamento foram utilizados quatro fardos de cada tratamento da farinha de trigo para as análises tecnológicas. Mensalmente foi retirado um fardo de cada tratamento da farinha de trigo e do fubá (controle, 
3, 4,5 e 6 kGy), sendo que de cada fardo se utilizaram três pacotes para as análises químicas e um para a análise sensorial. Todas as análises químicas foram determinadas em triplicatas para cada embalagem.

As análises de grau de umidade, teor de óleo, índice de peróxido, índice de acidez e absorbância específica foram realizadas mensalmente para ambas as farinhas (trigo e fubá).

Devido à maior presença dos carotenóides no fubá, acreditava-se que ocorreria uma alteração na cor de maior proporção neste, e por essa razão a análise de cor objetiva foi realizada mensalmente para o fubá e somente no início do experimento para a farinha de trigo, sendo realizada triplicata de cada leitura.

Conforme a literatura, as doses de irradiação aplicadas deveriam provocar pouca alteração na qualidade da proteína, sendo assim as análises de solubilidade de proteína foram realizadas somente nos meses 0, 3 e 6, para 0 fubá, e 0 e 3, para a farinha de trigo.

No primeiro mês de armazenamento foram utilizados quatro fardos de cada tratamento da farinha de trigo para análises tecnológicas. As alterações dos componentes da farinha de trigo se revelaram no seu desempenho na panificação. Os moinhos comerciais determinam o grau de alteração através de equipamentos que mecanicamente determinam a qualidade da farinha. Neste experimento, logo após a irradiação, determinou-se o grau da alteração causada pela irradiação na qualidade tecnológica farinha de trigo através dos testes, alveograma, farinograma e "Falling Number". Um outro teste comumente utilizado pelos moinhos é o teste de panificação com a produção de pão francês, que foi realizado logo após a irradiação (mês 0).

As farinhas foram avaliadas sensorialmente quanto à aparência, de maneira geral, cor e odor em todos os meses do armazenamento.

$A$ viscosidade das farinhas foi determinada apenas no último mês de armazenamento e comparada com uma farinha recém produzida e adquirida no comércio local. 


\subsection{Umidade}

As farinhas foram pesadas $(2 \mathrm{~g})$ e levadas a uma estufa de circulação de ar a $105^{\circ} \mathrm{C}$ até peso constante segundo o método $\mathrm{n} . .^{\circ} 44-15 \mathrm{~A}$ do AACC (2000).

O resultado foi expresso segundo a fórmula 1.

$$
\text { Grau de umidade }(\%)=\frac{[\text { massa inicial }(\mathrm{g})-\text { massa final }(\mathrm{g})]}{\text { massa inicial }(\mathrm{g})} \times 100
$$

\subsection{Cor objetiva}

A cor objetiva das amostras de farinha de trigo e fubá submetidos às diferentes doses de irradiação foi medida em colorímetro Minolta CR200b através dos parâmetros coloração, brilho e saturação de cores. Foram feitas três medidas da amostra, avaliando os seguintes aspectos: a) valores de $a^{*}$ : tons que vão do verde azulado (-60) até a vermelha púrpura (+60); b) valores de $b^{*}$ : tons que vão do amarelo (+60) até o azul (-60); valores de L: indicados pelas coordenadas de $a^{*}$ e $b^{*}$, num plano retangular de eixos (Figura 6), destacando a luminosidade da coloração entre tons de branco e preto.

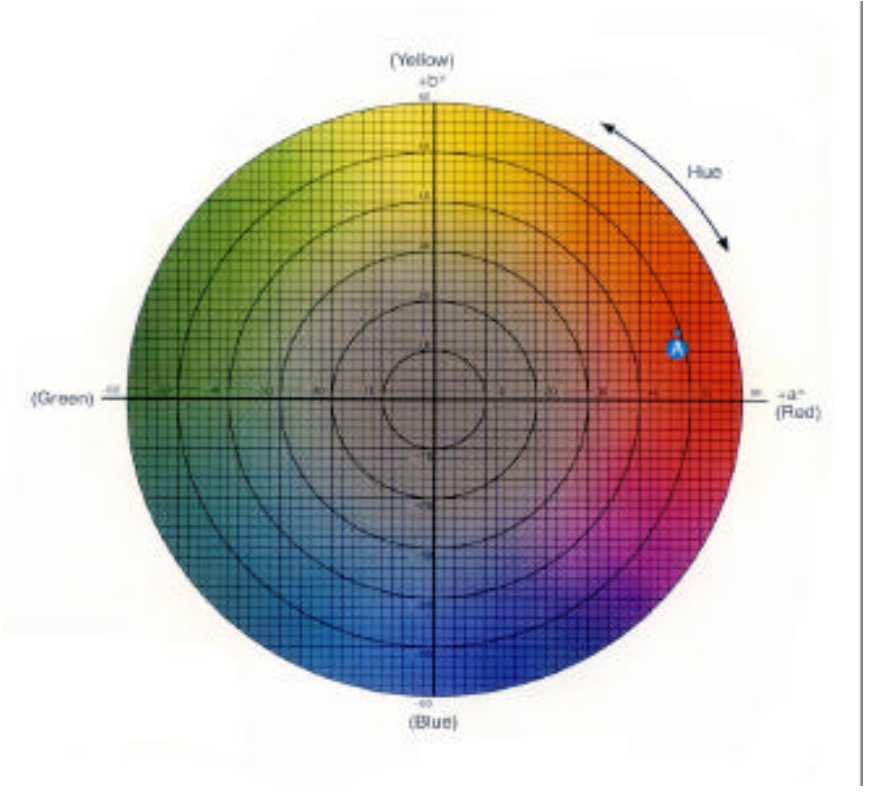

Figura 6 - Carta de cores $L, a^{*}, b^{*}$. 


\subsection{Teor de óleo}

Foi determinado através de um método modificado de Bligh \& Dyer (1959), que se baseia na extração dos lipídeos a frio, de modo que os extratos (miscelas) podem ser utilizados para avaliar com grande fidelidade o grau de deterioração dos lipídeos e sua quantificação.

Para a extração dos lipídeos, foram pesados aproximadamente $10 \mathrm{~g}$ de cada amostra em triplicata. Em um erlenmeyer foram adicionados $50 \mathrm{ml}$ de metanol, $25 \mathrm{ml}$ de clorofórmio e água (em quantidade dependente da umidade do produto que somado à água da amostra resulte em $20 \mathrm{ml}$ ). Após este procedimento o erlenmeyer foi tampado e colocado em um agitador por 30 minutos. Em seguida foram adicionados mais $25 \mathrm{ml}$ de clorofórmio e $25 \mathrm{ml}$ de solução de sulfato de sódio 1,5\%. Agitou-se o erlenmeyer tampado por mais 2 minutos. A solução com a amostra foi transferida para um funil de separação onde se esperou a separação. Recolheu-se a camada inferior (clorofórmio + lipídio) através de um funil pequeno com papel de filtro, o qual continha uma camada de sulfato de sódio anidro para remover traços de água, para um erlenmeyer de $100 \mathrm{ml}$. Retirou-se uma alíquota de $10 \mathrm{ml}$ desta miscela, e em um erlenmeyer de $25 \mathrm{ml}$ previamente tarado, evaporou-se o solvente em estufa até peso constante, para a quantificação do total de óleo. O restante da miscela foi utilizado para as determinações que se seguem. 


\section{4 Índice de acidez}

Foi determinado na miscela produzida pelo item 3.3.

Foram utilizados $10 \mathrm{ml}$ da miscela produzida durante a extração, adicionados de três gotas de fenolftaleina, e foi conduzida a titulação com solução de hidróxido de sódio a $0,01 \mathrm{~N}$ padronizada até o ponto de viragem.

O índice de acidez foi calculado através da fórmula (2).

$$
\frac{\text { I.A. }=V \times N \times f C}{M}
$$

Onde:

$\mathrm{V}=$ volume gasto da solução hidróxido de sódio $(\mathrm{ml})$

$\mathrm{N}=$ normalidade da solução de hidróxido de sódio

fc = fator de correção da concentração da solução padronizada de hidróxido de sódio

$\mathrm{M}=$ massa de óleo na alíquota de $10 \mathrm{ml}$ de miscela $(\mathrm{g})$

\section{5 Índice de peróxido}

O índice de peróxido foi determinado na miscela produzida pelo item 3.3. O método determina todas as substâncias, em miliequivalentes de peróxido por $1000 \mathrm{~g}$ de amostra, as quais oxidam o iodeto de potássio nas condições do teste. Para esta determinação foram utilizados $20 \mathrm{ml}$ de miscela de cada amostra, colocados em um erlenmeyer de $250 \mathrm{ml}$ e adicionados de $30 \mathrm{ml}$ de ácido acético concentrado e $0,5 \mathrm{ml}$ de solução fresca de iodeto de potássio saturado. Agitourse e deixou o erlenmeyer tampado por 1 minuto em local escuro. Após 1 minuto, adicionaram-se $30 \mathrm{ml}$ de água destilada e $1 \mathrm{ml}$ de solução de amido como indicador. Procedeu-se a titulação com solução de tiossulfato de sódio a 0,01N padronizada com agitação constante.

O índice de peróxido foi calculado através da fórmula (3):

$$
\text { I.P. }=\frac{(S-B) \times N \times f c \times 1000}{P \times 2}
$$


Onde:

$\mathrm{S}=$ volume de tiossulfato de sódio gasto na titulação da amostra $(\mathrm{ml})$

$\mathrm{B}=$ volume de tiossulfato de sódio gasto na titulação da testemunha $(\mathrm{ml})$

$\mathrm{N}=$ normalidade da solução de tiossulfato de sódio

$\mathrm{fc}=$ fator de correção da concentração da solução padronizada de tiossulfato de sódio

$\mathrm{M}=$ massa de óleo na alíquota de $10 \mathrm{ml}$ de miscela.

\subsection{Absorbância específica na faixa do ultravioleta}

A absorbância específica na faixa de 232 e $270 \mathrm{~mm}$ do ultravioleta foi determinada pelo método II.D.22 (IUPAC, 1979). Consiste na determinação da absorbância da fração lipídica dissolvida em um solvente apolar opticamente transparente na faixa do UV, revelando o seu estado de deterioração oxidativa. A determinação da absorbância a 232 e $270 \mathrm{~nm}$ indica a presença de produtos primários e secundários de oxidação.

Como o teor de óleo das farinhas (trigo e fubá) é relativamente baixo, o preparo das amostras se deu pela extração conforme uma metodologia modificada de Hara \& Radin (1978), utilizando o ciclohexano como solvente o que permitiu a leitura direta da miscela no espectrofotômetro (Evangelista, 1996).

\subsection{Solubilidade protéica}

As farinhas (trigo e fubá) submetidas àirradiação foram avaliadas quanto à qualidade de proteína, isto é, quanto à sua capacidade de solubilização em meio aquoso, conforme metodologia da AOCS nำ11-65 (1997), nos meses 0, 3, 6 .

\subsection{Qualidade tecnológica da farinha de trigo}

\subsubsection{Farinograma}

A farinografia é um dos mais completos e sensíveis testes de avaliação e controle de qualidade da farinha de trigo. 
Foi realizada em farinógrafo Brabender do Laboratório de Controle de Qualidade do Moinho São Valentim da Cargill em Tatuí, SP, conforme metodologia 54-21 da AACC (2000).

\subsubsection{Alveograma}

Foi realizada no alveógrafo Babender do Laboratório de Controle de Qualidade do Moinho São Valentim da Cargill em Tatuí, SP, segundo a metodologia 54-30A da AACC (2000).

\subsection{3 "Falling number"}

Em tubos de ensaio do aparelho "Falling number" da Peter Instruments do Laboratório de Controle de qualidade do Moinho São Valentim da Cargill em Tatuí, SP, foram separadamente colocados sete gramas de farinha de cada amostra em duplicata e adicionados $25 \mathrm{ml}$ de água destilada. Os tubos foram fechados e fortemente agitados até a homogeneização da suspensão. As rolhas foram retiradas dos tubos e a suspensão, que ficou retida na parte superior do tubo, foi removida com auxílio das próprias hastes do aparelho. Após o ajuste dos tubos no aparelho, o mesmo foi colocado em operação. Após a operação ter sido completada, os resultados foram obtidos diretamente do equipamento e expressos em segundos (método 56-81B, AACC, 2000).

\subsubsection{Teste de panificação}

Foi realizado na padaria piloto do Laboratório de Controle de Qualidade do Moinho São Valentim da Cargill em Tatuí, SP.

As mesmas condições de testes foram aplicadas a todos os tratamentos.

De cada tratamento foram tomados $2000 \mathrm{~g}$ de farinha no tempo inicial para a produção do pão francês. A essa farinha foram adicionados $40 \mathrm{~g}$ de sal, $28 \mathrm{~g}$ de fermento biológico, $20 \mathrm{~g}$ de melhorador de massa e $1240 \mathrm{ml}(62 \%)$ de água a $6^{\circ} \mathrm{C}$, que produziu uma massa com $30^{\circ} \mathrm{C}$. 
As temperaturas determinadas durante 0 teste foram de $27^{\circ} \mathrm{C}$ no ambiente, $29,5^{\circ} \mathrm{C}$ na estufa e de $235^{\circ} \mathrm{C}$ no forno.

Para avaliar o rendimento foram observados peso da massa modelada, peso do pão, perda de umidade e rendimento para $50 \mathrm{~kg}$.

A análise de volume específico (peso por volume) de pães é um dos principais no controle de qualidade da panificação, principalmente quando se busca a padronização dos produtos. Um equipamento chamado de medidor de volume da marca Vondel foi utilizado para esta análise.

Para a determinação do índice de qualidade das farinhas os resultados foram baseados em observação, e cada item observado recebeu uma pontuação, qual seja, I: insatisfatório (3 pontos), R: ruim (5 pontos), B: bom (8 pontos) e $\mathrm{O}$ : ótimo (10 pontos). A pontuação foi multiplicada pelo fator de significância (FT), adotado pelo moinho São Valentim (Tabela 1) Tabela 1. Índice de qualidade da massa de pão francês.



\subsection{Análise sensorial}

A análise sensorial foi conduzida através do método afetivo, para os atributos de aparência, cor e aroma. As amostras foram retiradas dos invólucros e colocadas em placa de Petri de $15 \mathrm{~cm}$ de diâmetro, tampadas e conservadas à temperatura ambiente durante a apresentação. Uma equipe de 25 provadores avaliou as amostras irradiadas e o controle, sobre os quais expressaram atributos dentro de uma escala de 0 a 8 pontos. Os provadores foram treinados com as escalas a serem utilizadas.

Foram realizadas quatro sessões, correspondentes aos períodos de 
armazenamento da farinha de trigo e sete sessões para o fubá. Para os três parâmetros (aparência, cor e aroma) foi utilizada uma escala graduada de 8 pontos, variando de "gostei extremamente" (nota 8) a "desgostei extremamente" (nota 0), como pode ser observada na ficha de avaliação sensorial (Figura 7). As amostras foram casualizadas, identificadas com números de três dígitos durante a apresentação ao provador. 


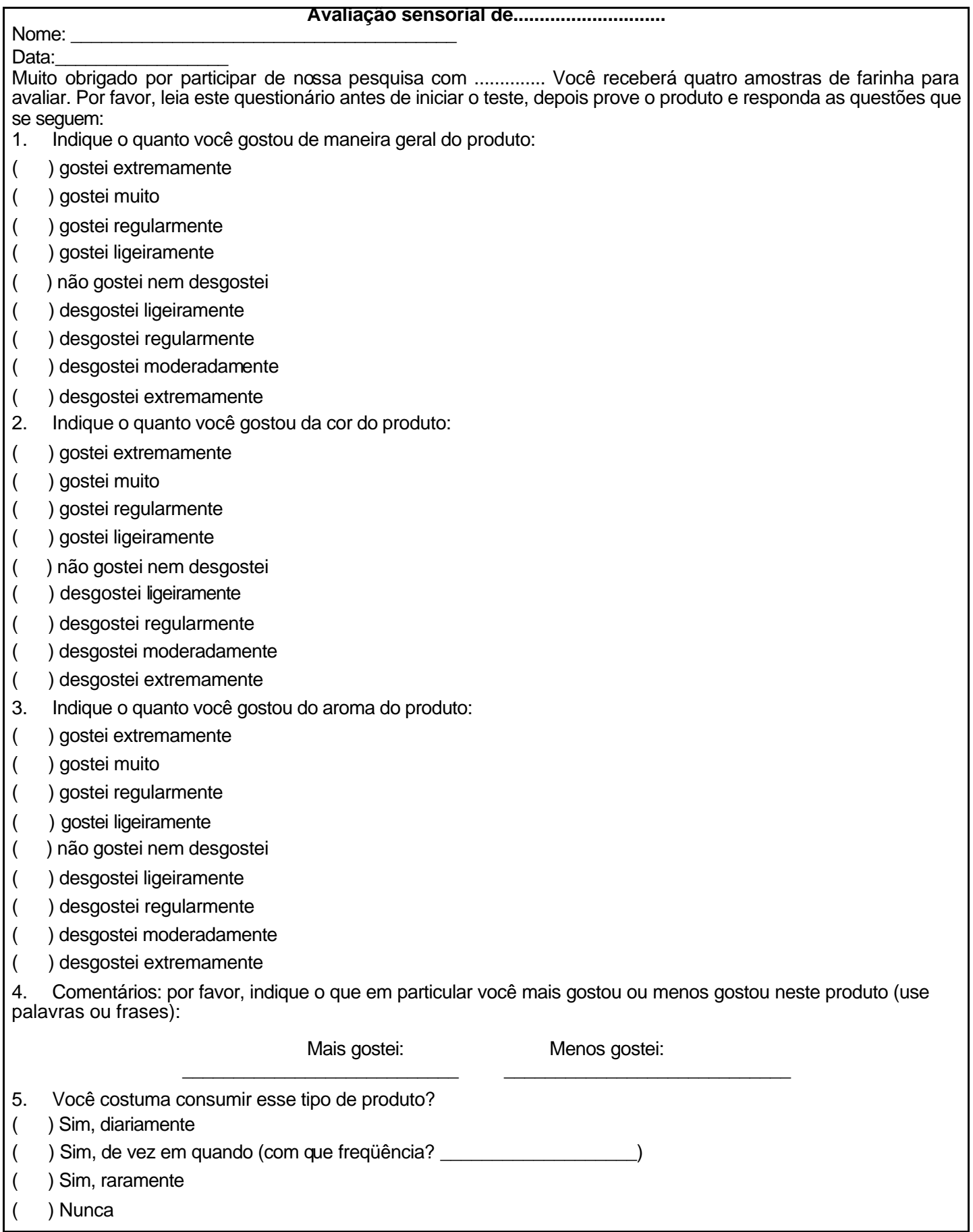

Figura 7 - Ficha de avaliação sensorial das amostras de farinha de trigo e fubá. 


\subsection{Viscosidade}

A análise da viscosidade da suspensão de farinha a $5 \%$ foi realizada no aparelho Rapid Visco Analyser (RVA - 4 da Newport Scientific), utilizando a programação standard 1 (13 minutos), no final do experimento.

Para o preparo da amostra foi necessário determinar previamente o grau de umidade da amostra, pois a quantidade de água a ser adicionada deve ser corrigida pela umidade já presente na amostra.

Foram pesados $2 \mathrm{~g}$ da farinha e adicionados de aproximadamente 20 a 24 $\mathrm{ml}$ de água, conforme a umidade da amostra, no copo. A leitura foi feita com a farinha hidratada e foi determinado o pico de viscosidade.

\subsection{Delineamento experimental}

O delineamento experimental para as análises físico-químicas foi conduzido em blocos casualizados, com os tratamentos dispostos em esquema fatorial $4 X 4$, referentes a quatro níveis de dose ( $0 ; 3 ; 4,5$ e 6 kGy) e quatro períodos de análise para a farinha de trigo e $4 X 7$, para o fubá ( $1^{\circ}$ dia e 6 meses de armazenamento), com três ou quatro repetições por tratamento.

Os resultados obtidos foram submetidos à análise estatística de acordo com o esquema de análise de variância que se encontra na Tabela 2 para farinha de trigo e Tabela 3 para o fubá.

Tabela 2. Esquema de análise de variância utilizada nos resultados das análises físico-químicas, e sensoriais da farinha de trigo.

\begin{tabular}{ll}
\hline C.V. & G.L. \\
\hline Dose (D) & 3 \\
Período (P) & 3 \\
D*P & 9 \\
Resíduo & 32 \\
Total & 47 \\
\hline
\end{tabular}


Tabela 3. Esquema de análise de variância utilizada nos resultados das análises físico-químicas, e sensoriais do fubá.

\begin{tabular}{ll}
\hline C.V. & G.L. \\
\hline Dose (D) & 3 \\
Período (P) & 6 \\
$D^{*} P$ & 18 \\
Resíduo & 56 \\
Total & 83 \\
\hline
\end{tabular}

$A$ análise estatística teve continuidade quando o teste $F$ foi significativo $(p<0,05)$, aplicando-se análise de regressão polinomial até $2^{\circ}$ grau $(=0,05)$. 


\section{RESULTADOS E DISCUSSÃO}

\subsection{Umidade}

As alterações no grau de umidade estão associadas ao caráter higroscópico da farinha e sua conseqüente tendência a responder às variações da umidade relativa do ambiente de armazenamento, conforme as propriedades de transferência de vapor de água através do material da embalagem.

A Tabela 4 apresenta as médias dos valores de Umidade Relativa (UR\%) e Temperatura Ambiente ( $\mathrm{T}^{\circ} \mathrm{C}$ ) que foram anotadas no dia da análise mensal e no local do armazenamento, durante todo o período do experimento. Estas se mantiveram constantes conforme eram esperadas para a época do ano em que foram realizadas as análises.

Tabela 4. Médias de Umidade Relativa (\%) e Temperatura (ํㅡ) dos meses de experimento (ano de 2001).

\begin{tabular}{cccccccc}
\hline & Jun & Jul & Ago & Set & Out & Nov & Dez \\
\cline { 2 - 8 } Tempo & 0 & 1 & 2 & 3 & 4 & 5 & 6 \\
\hline UR\% & 64 & 65 & 65 & 67 & 69 & 68 & 70 \\
Tㅇ & 19,8 & 19,9 & 20,2 & 21,4 & 21,4 & 24,7 & 25,2 \\
\hline
\end{tabular}

Os graus de umidade da farinha de trigo durante o armazenamento, são apresentados na Tabela 5, onde se observa que não ocorreu diferença significativa entre os tratamentos (doses 0, 3, 4,5 e $6 \mathrm{kGy}$ ) em nenhum dos quatro tempos de armazenamento (tempo 0, 1; 2; e 3). Os graus de umidade durante os quatro tempos de armazenamento (tempo 0, 1, 2 e 3) se mantiveram estáveis, apresentando médias que variaram de 11,28 a 12,58\%. A partir destes 
dados pode-se afirmar que as condições de armazenamento foram adequadas, com a manutenção da umidade da farinha a valores próximos ao inicial, muito importante na conservação de produtos farináceos.

O período inicial foi o que apresentou os mais baixos valores de umidade $(11,47 \%)$. Apesar da umidade ter aumentado durante o período de armazenamento, ela se manteve dentro da faixa de especificação da ANVISA (2001) para comercialização de farinha de trigo, que permite teores de até $15 \%$.

Tabela 5. Grau de umidade (\%) da farinha de trigo irradiada e armazenada ao ambiente.

\begin{tabular}{ccccc}
\hline & \multicolumn{4}{c}{ Tempo (Mês) } \\
\cline { 2 - 4 } Tratamento (kGy) & 0 & 1 & 2 & 3 \\
\hline 0 & $11,64^{\mathrm{aA}}$ & $12,24^{\mathrm{AB}}$ & $12,44^{\mathrm{y}}$ & $12,25^{\mathrm{aB}}$ \\
3 & $11,28^{\mathrm{aA}}$ & $12,19^{\mathrm{aB}}$ & $12,28^{\mathrm{aB}}$ & $12,26^{\mathrm{aB}}$ \\
4,5 & $11,70^{\mathrm{aA}}$ & $12,05^{\mathrm{aAB}}$ & $12,40^{\mathrm{aB}}$ & $12,58^{\mathrm{aAb}}$ \\
6 & $11,28^{\mathrm{aA}}$ & $12,30^{\mathrm{aB}}$ & $12,26^{\mathrm{aB}}$ & $12,31^{\mathrm{aB}}$ \\
\hline
\end{tabular}

\footnotetext{
${ }^{A B}$ letras maiúsculas indicam diferença significativa $p<0,05$ entre as colunas

${ }^{a b}$ letras minúsculas indicam diferença significativa $p<0,05$ entre as linhas

Coeficiente de variação: $2,451 \%$
}

A umidade do fubá oscilou muito durante o experimento (tabela 6), entretanto apesar de terem sido significativas estas oscilações, os graus de umidade nunca ultrapassaram o permitido pela egislação (ANVISA, 2001), ou seja, em nenhum dos períodos avaliados foi superior a $15 \%$. Acredita-se que apesar de terem sido armazenados nas mesmas condições de ambiente que a farinha de trigo, o fubá não se comportou da mesma maneira por estar em embalagens de permeabilidade diferente, permitindo ao fubá uma resposta maior e mais rápida às oscilações do ambiente. Além disso, como o período de armazenamento do fubá foi de seis meses, a faixa variação da temperatura e umidade relativa ambiente foi maior como visto na tabela 4. 
Tabela 6. Grau de umidade (\%) do fubá irradiado e armazenado ao ambiente.

\begin{tabular}{|c|c|c|c|c|c|c|c|}
\hline \multirow{2}{*}{ Tratamento (kGy) } & \multicolumn{7}{|c|}{ Tempo (Mês) } \\
\hline & 0 & 1 & 2 & 3 & 4 & 5 & 6 \\
\hline 0 & $9,89^{b c}$ & $10,64^{\mathrm{aAB}}$ & $10,42^{2 B C}$ & $9,91^{b C}$ & $11,22^{2 \mathrm{~A}}$ & $10,17^{b \in B C}$ & $9,86^{b c}$ \\
\hline 3 & $9,3^{\mathrm{aA}}$ & $10,57^{c C}$ & $9,99^{\mathrm{aA}}$ & $9,91^{\mathrm{aAB}}$ & $10,75^{\mathrm{bB}}$ & $10,42^{\mathrm{aA}}$ & $9,99^{\mathrm{aAB}}$ \\
\hline 4,5 & $9,96^{\mathrm{bBC}}$ & $10,46^{\mathrm{bBC}}$ & $10,67^{\mathrm{aAB}}$ & $9,51^{\mathrm{aA}}$ & $10,68^{b C}$ & $10,1^{\mathrm{abA}}$ & $9,91^{\mathrm{abABC}}$ \\
\hline 6 & $10,09^{\mathrm{bA}}$ & $10,36^{\mathrm{bA}}$ & $10,34^{\mathrm{aA}}$ & $9,98^{\mathrm{abA}}$ & $10,06^{\mathrm{bA}}$ & $10,35^{\mathrm{CA}}$ & $11,06^{\mathrm{abA}}$ \\
\hline
\end{tabular}

\footnotetext{
${ }^{A B}$ letras maiúsculas indicam diferença significativa $p<0,05$ entre as colunas

ab letras minúsculas indicam diferença significativa $p<0,05$ entre as linhas

Coeficiente de variação: $2,298 \%$
}

A granulometria fina da farinha promove rápidas respostas æ̇s alterações da umidade no armazenamento (Bailey,1925). Marathe et al. (2002) também verificaram um pequeno aumento na umidade de farinha de trigo irradiada depois de três meses de armazenamento e atribuíram-no àpermeabilidade da embalagem, que permitiu uma pequena troca de umidade com o ambiente.

Os resultados de grau de umidade encontrados neste trabalho, indicam que essa característica não é afetada pela irradiação e são semelhantes aos resultados encontrados por Lai et al. (1959) que estudaram o efeito da irradiação em duas variedades de trigo e suas farinhas em diferentes doses 0,1 ; 0,3; 0,6; $1,0 \times 10^{6}$ rep (1,3,6, e 10KGy, respectivamente) e não encontraram diferença significativa entre as doses e uma amostra controle, obtendo uma média de umidade de $11,7 \%$.

\subsection{Cor objetiva}

A farinha de trigo deve apresentar cor branca, com tons leves de amarelo, marrom ou cinza, conforme o trigo de origem (Port. $n^{\circ} 354$, de 18/08/96, MS - SVS).

A cor é uma propriedade de aparência atribuída à distribuição espectral da luz. A primeira impressão que se tem de um alimento é geralmente visual, 
sendo que a maior parte da nossa tendência em aceitá-lo depende de sua cor (Silva, 1973).

A cor da farinha está diretamente relacionada ao seu grau de qualidade. Quanto mais branca for a farinha de trigo, por exemplo, maior será a sua qualidade e mais alta a sua classificação. O valor "L", que indica a intensidade do branco é o mais importante parâmetro para se avaliar a qualidade de farinha de trigo. Na Figura 8 é apresentada a carta de cores.

Apesar de não existir nenhuma especificação na legislação quanto àcor do fubá, este parâmetro é de grande importância para sua qualidade e de aceitação pelo consumidor.

As doses de irradiação aplicadas nas farinhas produziram alterações sutis na coloração, porém presentes, perceptíveis e provavelmente decorrentes deste método de conservação.

A luminosidade das amostras $(L)$ da farinha de trigo diminuiu progressivamente até a dosagem de $6 \mathrm{kGy}$. Isto significa que conforme o incremento na a dose de irradiação, a farinha de trigo se tornou menos luminosa, ou seja, mais escura (Tabela 7).

Os valores de "a*" indicam que os tons muito claros de verde que foram reduzidos quando amostra foi irradiada com $3 \mathrm{kGy}$, permaneceram estáveis com 4,5 kGy, e foram novamente reduzidos quando a farinha de trigo recebeu 6 kGy de irradiação (Tabela 7).

Os tons de vermelho, indicados pelo valor " $b$ ", foram reduzidos gradativamente até a dosagem 4,5 kGy (Tabela 7). Esta ocorrência pode ser explicada pela perda de carotenóides, citada por Pomeranz et al. (1956) e Deischreider (1966), que relataram o desaparecimento total dos carotenóides quando a dose chegou a 4Mrad (40 kGy) em farinha de trigo . O aumento do valor "b*" quando a amostra foi irradiada com 6 kGy, se deveu ao escurecimento da mesma e àpossível ocorrência da reação de Maillard. 
Tabela 7. Valores de $L, a^{*}, b^{*}$ nas diferentes doses no primeiro mês de armazenamento em farinha de trigo.

\begin{tabular}{ccccc}
\hline \multirow{2}{*}{ Parâmetros } & \multicolumn{5}{c}{ Tratamento (kGy) } \\
\cline { 2 - 5 } & 0 & 3 & 4,5 & 6,0 \\
\hline $\mathrm{b}^{*}$ & 9,54 & 9,52 & 9,46 & 9,54 \\
$\mathrm{a}^{*}$ & $-0,17$ & $-0,14$ & $-0,14$ & $-0,06$ \\
$\mathrm{~L}$ & 92,86 & 92,79 & 92,78 & 92,65 \\
\hline
\end{tabular}

Foram observadas as alterações ocorridas no fubá após 0 seu armazenamento, comparando os valores de $L, a^{*}$ e $b^{*}$ do inicio do experimento com os demais períodos.

Como se pode observar na Tabela 8, o fator $L$, que caracteriza a luminosidade das amostras de fubá, foi pouco alterado durante o período de seis meses de armazenamento, não sendo significativa entre os tempos. A irradiação causou uma diferença significativa nas médias do tratamento entre 0 controle e as demais doses de irradiação, refletindo o escurecimento das amostras irradiadas (Tabela 8).

Tabela 8. Valores de $L$ do fubá irradiado e armazenado ao ambiente.

\begin{tabular}{ccccccccc}
\hline \multirow{2}{*}{ Tratamento (kGy) } & \multicolumn{7}{c}{ Tempo (Mês) } & Médias do \\
\cline { 2 - 8 } & 0 & 1 & 2 & 3 & 4 & 5 & 6 & tratamento \\
\hline 0 & 86,16 & 86,01 & 86,35 & 87,16 & 86,98 & 86,88 & 86,47 & $86.57^{\mathrm{a}}$ \\
3 & 85,81 & 85,92 & 86,43 & 86,90 & 86,62 & 86,51 & 86,43 & $86.37^{\mathrm{b}}$ \\
4,5 & 85,47 & 85,98 & 86,19 & 86,81 & 86,54 & 86,50 & 86,43 & $86.27^{\mathrm{b}}$ \\
6 & 85,55 & 86,04 & 86,33 & 86,62 & 86,74 & 86,39 & 86,43 & $86.30^{\mathrm{b}}$ \\
\hline
\end{tabular}

\footnotetext{
${ }^{A B}$ letras maiúsculas indicam diferença significativa $p<0,05$ entre as colunas

${ }^{a b}$ letras minúsculas indicam diferença significativa $p<0,05$ entre as linhas

Coeficiente de variação: 0,221\%
}

A amostra controle diferiu significativamente das irradiadas em todos os tempos de armazenamento. Os maiores valores de $b^{*}$ foram encontrados na amostra controle, indicando assim que o tratamento de irradiação diminuiu a 
coloração amarela do fubá. Entre os tempos de armazenamento inicial e de um mês de armazenamento, foram encontrados os maiores valores de $b^{*}$. Essa perda da coloração amarela ocorreu mesmo na amostra não irradiada, porém foi mais acentuada com o tempo de armazenamento, sendo gradual com passar dos meses (Tabela 9).

Tabela 9. Valores de b do fubá irradiado e armazenado em ambiente.

\begin{tabular}{|c|c|c|c|c|c|c|c|}
\hline \multirow{3}{*}{ Tratamento } & \multicolumn{7}{|c|}{ Tempo (Mës) } \\
\hline & \multirow[b]{2}{*}{0} & \multirow[b]{2}{*}{1} & \multirow[b]{2}{*}{2} & \multirow[b]{2}{*}{3} & \multirow[b]{2}{*}{4} & \multirow[b]{2}{*}{5} & \multirow[b]{2}{*}{6} \\
\hline & & & & & & & \\
\hline 0 & $52,44^{2 A}$ & $52,26^{\mathrm{aAB}}$ & $51,37^{2 A B G}$ & $50,65^{a b}$ & $50,48^{a 6}$ & $50,66^{26}$ & $50,78^{a b}$ \\
\hline 3 & $48,73^{\mathrm{bA}}$ & $49,37^{\mathrm{bAB}}$ & $47,65^{\mathrm{bABC}}$ & $48,23^{\mathrm{bBCD}}$ & $47,52^{\mathrm{bBCD}}$ & $46,74^{\mathrm{bCD}}$ & $46,26^{\mathrm{bD}}$ \\
\hline 4,5 & $48,01^{\mathrm{bA}}$ & $48,18^{\mathrm{bA}}$ & $47,07^{\mathrm{bcA}}$ & $46,84^{\mathrm{CAB}}$ & $46,88^{\mathrm{bAB}}$ & $44,95^{\mathrm{cC}}$ & $45,35^{\mathrm{bcBC}}$ \\
\hline 6 & $48,01^{\mathrm{bA}}$ & $46,36^{\mathrm{cB}}$ & $46,04^{\mathrm{cBC}}$ & $46,60^{\mathrm{CAB}}$ & $46,21^{\mathrm{bB}}$ & $43,68^{c D}$ & $44,60^{\mathrm{cCD}}$ \\
\hline
\end{tabular}

\footnotetext{
$A B$ letras maiúsculas indicam diferença significativa $p<0,05$ entre as colunas

${ }^{a b}$ letras minúsculas indicam diferença significativa $p<0,05$ entre as linhas

Coeficiente de variação: $1,321 \%$
}

Os valores de $\mathrm{a}^{*}$ também foram reduzidos pelo tratamento, podendo-se dizer que a coloração vermelha foi alterada pela dose de irradiação. Como se observa a Tabela 10, essa perda da coloração vermelha foi progressiva àdose. Apesar de terem ocorrido algumas variações ao longo dos meses de armazenamento, percebese o tempo afetou as amostras, com a diminuição dos valores de $\mathrm{a}^{*}$.

Tabela 10 Valores de $a^{*}$ do fubá irradiado e armazenado ao ambiente.

\begin{tabular}{|c|c|c|c|c|c|c|c|}
\hline \multirow{2}{*}{ Tratamentos (kGy) } & \multicolumn{7}{|c|}{ Tempo (mês) } \\
\hline & 0 & 1 & 2 & 3 & 4 & 5 & 6 \\
\hline 0 & $-1,81^{2 A}$ & $-1,89^{2 A}$ & $-1,99^{2 A B}$ & $-1,88^{2 A}$ & $-1,90^{2 A}$ & $-2,19$ & $-2,36$ \\
\hline 3 & $-1,90^{\mathrm{aA}}$ & $-1,88^{\mathrm{aA}}$ & $-1,77^{\mathrm{aA}}$ & $-2,50^{\mathrm{CB}}$ & $-1,92^{\mathrm{aA}}$ & $-1,91^{\mathrm{aA}}$ & $-2,02^{\mathrm{aA}}$ \\
\hline 4,5 & $-1,95^{\mathrm{aAB}}$ & $-1,80^{\mathrm{aA}}$ & $-1,85^{\mathrm{aA}}$ & $-2,4^{b c c}$ & $-2,16^{\mathrm{abABC}}$ & $-2,29^{b B C}$ & $-2,42^{b c}$ \\
\hline 6 & $-1,96^{\mathrm{aAB}}$ & $-1,83^{\mathrm{aA}}$ & $-1,99^{\mathrm{aAB}}$ & $-2,2^{\mathrm{abAB}}$ & $-2,33^{b B}$ & $-2,31^{\mathrm{bB}}$ & $-2,23^{a b B}$ \\
\hline
\end{tabular}

\footnotetext{
${ }^{A B}$ letras maiúsculas indicam diferença significativa $p<0,05$ entre as colunas
} 
${ }^{a b}$ letras minúsculas indicam diferença significativa $p<0,05$ entre as linhas Coeficiente de variação: $-7,538 \%$

$\mathrm{Na}$ carta de cores apresentada na Figura 8 está assinalada a região onde se encontraram os valores $a^{*} e^{*}$ das farinhas irradiadas e controles.

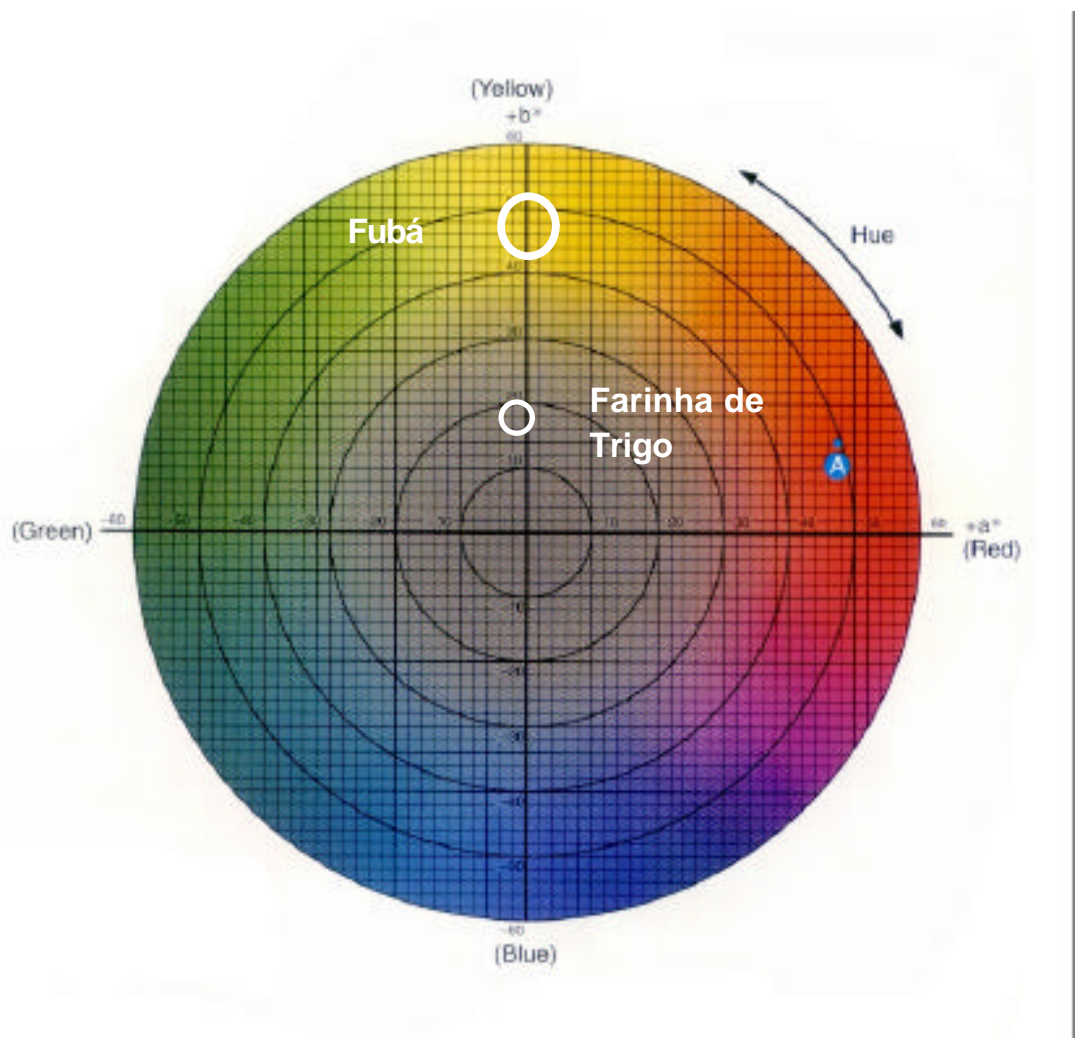

Figura 8 - Carta de Cores L, $a^{*}, b^{*}$.

Pelos valores $\mathrm{L}, \mathrm{a}^{*}, \mathrm{~b}^{*}$, percebe-se que com o aumento da dose de irradiação, a farinha de trigo ficou levemente mais escura, e o fubá, menos amarelo e menos vermelho. Lai et al. (1959) avaliaram a cor de farinhas irradiadas com dosagens que variaram de 100.000 a 1.000000 rep (1 a 10 kGy), através da grade de cor de Kent-Jones (1950). A perda de carotenóides, que ocorreu durante o processo, tornou as farinhas mais escuras devido a uma reação de escurecimento. Corwell (1966), que estudou extensivamente os efeitos da radiação gama em trigos e farinhas armazenados durante um ano, verificou o escurecimento como única modificação no tratamento na farinha 
irradiada com 20.000 rad (0,2 kGy). Yen et al. (1956) observaram esse escurecimento da farinha de trigo com altas doses de irradiação como em 1 Mrep (10 kGy) e atribuíram-no àreação de Maillard.

Entretanto, Marathe et al. (2002) não encontraram nenhuma alteração significativa na cor de farinhas de trigo integrais irradiadas com doses entre 0,25 a 1 kGy.

\subsection{Viscosidade}

O volume do pão é dependente da fermentação da massa, e essa fermentação é cependente da presença de amido e do conteúdo protéico da farinha. A levedura utilizada como fermento necessita do amido, que é um dos constituintes mais sensíveis à radiação. A radiação, por sua vez, provoca uma despolimerização do amido, que leva a um aumento dos teores de açúcares redutores. O aumento da produção autolítica de açúcares redutores no trigo irradiado é devido àmaior suscetibilidade do amido àhidrólise por diástases. A desnaturação dos polissacarídeos reduz a viscosidade da pasta de amido devido àmaior solubilidade da fração amilopectina (Deschreider, 1965).

A Tabela 11 apresenta os valores de farinha de trigo de viscosidade medida no aparelho Rapid Visco Analyser observados no final do experimento. Nela pode-se verificar que a irradiação provocou uma séria perda de viscosidade. Além disso, o tempo de armazenamento pareceu acentuar esta perda da viscosidade da farinha, pois comparando a amostra padrão (recém embalada) com o tratamento controle armazenado por três meses, houve uma pequena diferença no valor desse parâmetro. Quando a farinha recebeu a irradiação, a queda na viscosidade foi brusca e proporcional àdose, chegando a uma perda de $83 \%$ no tratamento 6 kGy comparado àamostra controle. 
Tabela 11. Pico de viscosidade da farinha de trigo irradiada após três meses armazenamento.

\begin{tabular}{cc}
\hline Tratamento (kGy) & Pico de Viscosidade $\left(\mathrm{RVU}^{*}\right)$ \\
\hline Padrão & 203,25 \\
0 & 189,75 \\
3 & 101,00 \\
4,5 & 95,75 \\
6 & 32,25 \\
\hline *RVU-Rapid Visco Unit &
\end{tabular}

Diversos trabalhos encontrados na literatura relatam a ação do processo de irradiação na fração amido do alimento. Ananthaswamy et al. (1970) utilizaram altas doses de radiação e estas provocaram alterações nos carboidratos do trigo, tais como a redução do teor de amido e o aumento do teor total de açúcares redutores. A umidade do grão no momento da irradiação afetou o grau de alterações nos carboidratos. Altos valores de maltose foram produzidos com umidades mais altas no grão do trigo. Provavelmente a radiação induz mais rapidamente a despolimerização do amido em presença de alta umidade.

Assim como com a farinha de trigo, o fubá também teve a viscosidade alterada com a irradiação, chegando a uma perda de cerca de $78 \%$ em relação ao tratamento 0. A amostra padrão (recém embalada) apresentou um pico de viscosidade inferior ao da amostra controle, isso possivelmente devido à variação de qualidade obtida por lotes diferentes devido as diferentes variedades, épocas e locais de produção. 
Tabela 12. Pico de viscosidade do fubá após 6 meses armazenamento.

\begin{tabular}{cc}
\hline Tratamento (kGy) & Pico de Viscosidade (RVU*) \\
\hline Padräo & 434,83 \\
0 & 505,58 \\
3 & 234,83 \\
4,5 & 184,08 \\
6 & 112,92
\end{tabular}

${ }^{\star R V U}$ - Rapid Visco Unit

Segundo Ananthaswamy et al. (1970), baixas doses de raios gama de 20.000 a 150.000 rad $(0,2-1,5$ kGy) determinam um máximo nas curvas de viscosidade do amido, das substâncias precipitáveis por eletrodiálise, na solubilidade de gliadinas e no "Falling number", explicando assim a melhoria nas qualidades de panificação que alguns autores observaram em farinhas irradiadas com baixas doses de raios gama.

Lai et al. (1959) relataram como principais alterações de trigo irradiado, a diminuição do teor de amido, da viscosidade e da capacidade de gelatinização aumento do teor de maltose e a diminuição da capacidade de hidratação da proteína.

O presente trabalho confirmou os resultados da literatura, verificando uma redução do pico de viscosidade nos tratamentos de radiação mais elevados, que pode ser atribuída à perda de amido e aumento de carboidratos simples e uma possível, hidrólise do amido, conforme Ananthaswamy et al. (1970); Lai et al. (1959); Roushdi et al. (1983).

\subsection{Teor de óleo}

Os teores de óleo encontrados neste trabalho foram coerentes com da literatura, com médias de 2,02 a 1,55\%, para a farinha de trigo e 2,12 a 3,00\%, para o fubá (USP, 2002).

A irradiação não afetou o conteúdo de óleo da farinha de trigo, entretanto com o tempo de armazenamento as amostras apresentaram uma diminuição no 
total, que se deve provavelmente ao aumento de umidade apresentado no item 4.1. Os teores de óleo da farinha de trigo podem ser encontrados na Tabela 13. Não foi encontrada diferença significativa entre os tratamentos em nenhum dos períodos, entretanto, dentro do fator período, ocorreu uma diminuição no teor de óleo em todos os tratamentos, sendo essa diferença significativa. Os teores iniciais de óleo foram coerentes com os encontrados por Marathe et al. (2002).

Tabela 13. Teor de óleo (\%) da farinhas de trigo irradiada e armazenada ao ambiente.

\begin{tabular}{ccccc}
\hline & \multicolumn{4}{c}{ Tempo (Mês) } \\
\cline { 2 - 5 } Tratamento (kGy) & 0 & 1 & 2 & 3 \\
\hline 0 & $2,00^{\mathrm{aA}}$ & $1,64^{\mathrm{AB}}$ & $1,70^{\mathrm{AB}}$ & $1,47^{\mathrm{a}}$ \\
3 & $1,90^{\mathrm{aA}}$ & $1,81^{\mathrm{aA}}$ & $1,65^{\mathrm{aA}}$ & $1,62^{\mathrm{aA}}$ \\
4,5 & $1,97^{\mathrm{aA}}$ & $1,89^{\mathrm{aAB}}$ & $1,74^{\mathrm{aAB}}$ & $1,57^{\mathrm{aB}}$ \\
6 & $2,22^{\mathrm{aA}}$ & $1,69^{\mathrm{aB}}$ & $1,74^{\mathrm{aB}}$ & $1,57^{\mathrm{aB}}$ \\
\hline
\end{tabular}

\footnotetext{
${ }^{A B}$ letras maiúsculas indicam diferença significativa $p<0,05$ entre as colunas

${ }^{\mathrm{ab}}$ letras minúsculas indicam diferença significativa $\mathrm{p}<0,05$ entre as linhas

Coeficiente de variação: $9,274 \%$
}

Os teores de óleo do fubá apresentaram uma grande variação, possivelmente produzida pela oscilação da umidade do fubá apresentada no ítem 4.1. A Tabela 14 mostra os teores de óleo do fubá irradiado durante o armazenamento. Apesar de existir diferença significativa entre os períodos de armazenamento, essa diferença foi muito pequena, não alterando a qualidade do produto. 
Tabela 14. Teor de óleo (\%) do fubá irradiado e armazenado ao ambiente.

\begin{tabular}{|c|c|c|c|c|c|c|c|}
\hline \multirow[b]{2}{*}{ Tratamento (kGy) } & \multicolumn{7}{|c|}{ Tempo (Mês) } \\
\hline & 0 & 1 & 2 & 3 & 4 & 5 & 6 \\
\hline 0 & $2,48^{2}$ & $2,90^{2 A B}$ & $3,06^{2 n}$ & $2,08^{26}$ & $3,17^{2 n}$ & $2,37^{b c}$ & $2,49^{2 B C}$ \\
\hline 3 & $2,26^{\mathrm{aC}}$ & $2,90^{\mathrm{aAB}}$ & $2,90^{\mathrm{aAB}}$ & $2,24^{\mathrm{aC}}$ & $3,10^{\mathrm{abA}}$ & $2,56^{\mathrm{abBC}}$ & $2,46^{\mathrm{aBC}}$ \\
\hline 4,5 & $2,29^{\mathrm{aCD}}$ & $3,02^{\mathrm{aA}}$ & $3,0^{a A}$ & $2,14^{\mathrm{aD}}$ & $2,73^{\mathrm{ab} A B C}$ & $2,88^{\mathrm{aAB}}$ & $2,51^{\mathrm{aBCD}}$ \\
\hline 6 & $2,31^{\mathrm{aCD}}$ & $2,78^{\mathrm{aAB}}$ & $2,94^{\mathrm{aA}}$ & $2,05^{\mathrm{aD}}$ & $3,05^{\mathrm{bA}}$ & $2,48^{\mathrm{bBCD}}$ & $2,66^{\mathrm{aABC}}$ \\
\hline
\end{tabular}

${ }^{A B}$ letras maiúsculas indicam diferença significativa $p<0,05$ entre as colunas

${ }^{a b}$ letras minúsculas indicam diferença significativa $p<0,05$ entre as linhas

Coeficiente de variação: 6,947\%

Hannis \& Mnukova (1985) verificaram que doses de radiação de até 10 kGy, não causaram nenhuma alteração nos lipídios dos cereais. A aplicação de altas doses pode levar a algumas mudanças em função do tipo e composição do lipídio, da presença de antioxidantes, composição do cereal irradiado, e condições de irradiação (Delincee, 1983; Nawar, 1983). Lai et al. (1959) também não encontraram nenhuma modificação no conteúdo de ácidos graxos de farinhas irradiadas, concluindo assim que irradiação não causou hidrólise dos lipídios.

Tipples \& Norris (1965) verificaram que a radiação gama produziu pequenas alterações na fração lipídica do trigo. Os teores de ácidos graxos linoléico e linolênico diminuíram lentamente, mas só passaram a ser significativos em altas doses como 1Mrad (10 kGy) e os ácidos graxos não esterificados aparentemente foram mais susceptíveis à irradiação do que os esterificados.

\section{5 Índice de acidez}

Os lipídeos do grão são passíveis de sofrerem quebra pelas lipases em ácidos graxos livres e glicerol durante o armazenamento, especialmente quando a temperatura e a umidade estão altas e, assim, favorecem a deterioração. 
A irradiação provocou alteração nas farinhas quanto ao teor de ácidos graxos livres, e essa alteração foi maior quanto maior a dose de irradiação. Além disso, o armazenamento, como era esperado, causou danos hidrolíticos nos lipídeos das farinhas e esse dano foi agravado pela irradiação.

O índice de acidez da farinha de trigo controle aumentou gradativamente com o tempo de armazenamento (Tabela 15). Os resultados foram diferentes quando a amostra recebeu $3 \mathrm{kGy}$, pois o índice de acidez da farinha se apresentou relativamente alto no início do experimento, manteve-se durante 0 armazenamento, sofrendo um aumento no último mês. As farinhas irradiadas com 4,5 kGy e 6 kGy foram as que apresentaram os maiores índices iniciais, que apesar de terem sido reduzidos durante o armazenamento, após três meses ainda foram superiores aos demais.

Tabela 15. Índice de acidez (\%) das farinhas de trigo irradiadas e armazenadas ao ambiente.

\begin{tabular}{cllll}
\hline \multirow{2}{*}{ Tratamento (kGy) } & \multicolumn{4}{c}{ Tempo (Mës) } \\
\cline { 2 - 5 } & 0 & 1 & 2 & 3 \\
\hline 0 & $5,02^{\mathrm{aA}}$ & $5,29^{\mathrm{aA}}$ & $5,60^{\mathrm{a}^{\mathrm{A}}}$ & $6,40^{\mathrm{a}} \mathrm{B}$ \\
3 & $6,37^{\mathrm{bA}}$ & $6,62^{\mathrm{abA}}$ & $5,90^{\mathrm{a}} \mathrm{A}$ & $5,30^{\mathrm{abA}}$ \\
4,5 & $7,72^{\mathrm{bA}}$ & $5,43^{\mathrm{bcB}}$ & $6,33^{\mathrm{a}} \mathrm{AB}$ & $6,95^{\mathrm{bB}}$ \\
6 & $8,31^{\mathrm{bA}}$ & $5,97^{\mathrm{CB}}$ & $6,07^{\mathrm{aB}}$ & $7,35^{\mathrm{abC}}$ \\
\hline
\end{tabular}

\footnotetext{
AB letras maiúsculas indicam diferença significativa $p<0,05$ entre as colunas

${ }^{a b}$ letras minúsculas indicam difereça significativa $p<0,05$ entre as linhas

Coeficiente de variação: $12,080 \%$
}

A irradiação teve um efeito muito maior sobre a qualidade da fração lipídica das amostras de fubá. Os índices de acidez iniciais foram superiores aos da farinha de trigo (Tabela 16). A índices de acidez iniciais mais altos corresponderam incrementos maiores com o tempo de armazenagem. A análise estatística confirmou essa tendência. 
Dentre todos os ídices analíticos, o índice de acidez foi o que mais prontamente refletiu a ação da irradiação.

Tabela 16. Índice de acidez do fubá irradiado e armazenado ao ambiente.

\begin{tabular}{|c|c|c|c|c|c|c|c|}
\hline \multirow[b]{2}{*}{ Tratamento (kGy) } & \multicolumn{7}{|c|}{ Tempo (Mês) } \\
\hline & $\overline{0}$ & 1 & 2 & 3 & 4 & 5 & 6 \\
\hline 0 & $6,70^{2 n}$ & $8,19^{a}{ }^{A B}$ & $9,16^{a^{A B}}$ & $11,05^{a c}$ & $13,60^{260}$ & $15,74^{a^{D}}$ & $10,18^{26}$ \\
\hline 3 & $9,67^{\mathrm{bAB}}$ & $7,38^{\mathrm{aB}}$ & $8,15^{\mathrm{aB}}$ & $9,63^{\mathrm{aAB}}$ & $13,74^{\mathrm{a}^{\mathrm{B}}}$ & $13,74^{\mathrm{abB}}$ & $11,48^{\mathrm{aBC}}$ \\
\hline 4,5 & $9,33^{\mathrm{bAB}}$ & $7,12^{\mathrm{aBC}}$ & $5,55^{\mathrm{nC}}$ & $10,38^{\mathrm{aAD}}$ & $12,61^{\text {a }} \mathrm{DE}$ & $14,15^{\mathrm{abDE}}$ & $12,63^{\mathrm{aE}}$ \\
\hline 6 & $7,23^{\mathrm{abA}}$ & $7,90^{\mathrm{aA}}$ & $7,27^{\mathrm{abA}}$ & $10,85^{\mathrm{aB}}$ & $14,12^{\mathrm{a}^{\mathrm{C}}} \mathrm{C}$ & $12,43^{\mathrm{bBC}}$ & $12,44^{\mathrm{aBC}}$ \\
\hline
\end{tabular}

\footnotetext{
${ }^{A B}$ letras maiúsculas indicam diferença significativa $p<0,05$ entre as colunas

${ }^{a b}$ letras minúsculas indicam diferença significativa $\mathrm{p}<0,05$ entre as linhas

Coeficiente de variação: $11,21 \%$
}

$\mathrm{Na}$ alteração hidrolítica dos lipídeos ou lipólise, os ácidos graxos são liberados dos triglicerídeos. Assim, além do sabor desagradável, ocorre o aumento da acidez, susceptibilidade dos ácidos graxos às reações de oxidação e alterações das propriedades funcionais (Gutkoski \& Pedó, 2000). Tipples \& Norris (1965) relataram que o sabor indesejável em alimentos irradiados apresentou uma semelhança com o encontrado nos alimentos rançados.

\section{6 Índice de peróxido}

Não foi encontrado nenhum indício da presença de peróxidos em nenhum dos tratamentos e em nenhum dos períodos de armazenamento. Sendo assim pode-se dizer que as amostras apresentaram boa estabilidade oxidativa, mesmo sofrendo o tratamento de irradiação e armazenamento.

Urbain (1986) não encontrou alteração oxidativa na fração lipídica de farinha de trigo irradiada com doses entre 0,1 kGy e 1,75 kGy. Tipples \& Norris (1965) trabalharam com farinhas provenientes de trigo irradiado com doses de 0, 1, 10, 50, 100 kGy, armazenadas durante 6 meses e observaram um aumento do índice de peróxido paralelo ao aumento da dose de radiação. Os 
autores associaram o aumento do índice de peróxido a um odor não característico de farinha.

Com altas doses de radiação, da ordem de 100 kGy, ocorreram algumas alterações na fração lipídica, triglicerídeos, galactolipídeos e fosfolipídeos que se refletiram no maior teor de esteróis livres, monoglicerídeos e diglicerídeos. Tipples \& Norris (1965) observaram que a fração lipídica de farinhas irradiadas oxidou menos em seis meses de armazenamento que as farinhas não irradiadas. Além disso, no mesmo trabalho, os autores relataram que os teores de carotenóides, antioxidantes e tocoferóis diminuíram com o aumento da dose. Durante o armazenamento da farinha irradiada, os ácidos graxos foram oxidados mais lentamente que nas amostras controle, de forma que os valores de peróxidos na amostra controle apresentaram um aumento proporcional ao tempo enquanto que isso não aconteceu com as amostras não irradiadas. Tipples \& Norris (1965) sugeriram que esse aumento de peróxidos se deveu à destruição dos tocoferóis provocada pela irradiação, deixando a fração lipídica mais susceptível àoxidação.

\subsection{Absorbância específica no ultravioleta}

A oxidação de ácidos graxos polinsaturados pode ser acompanhada pelo aumento da absorção de luz pelos compostos formados na faixa do espectro ultravioleta. Lipídios contendo dienos e polienos sofrem uma alteração na posição de suas duplas ligações durante a oxidação, resultando na isomeração e conjugação. Os dienos conjugados exibem uma intensa absorção em 234nm, da mesma forma que trienos conjugados absorvem mais fortemente em 268nm (Shahidi, 1995).

Os compostos primários da oxidação apresentam absortividade máxima na faixa entre $220 \mathrm{~nm}$ e $234 \mathrm{~nm}$ (232 nm). Logo após a irradiação, as farinhas apresentaram um incremento nos valores de absortividade em relação ao controle, decorrente, provavelmente, da formação incipiente de peróxidos que provocou a formação de dienos por ressonância na cadeia do ácido graxo 
insaturado. Esses peróxidos (dienos), instáveis por natureza, devem ter se cindido com o tempo e a autoxidação não conseguiu manter os mesmos níveis iniciais de dienos, pois nos meses subseqüentes os níveis se mantiveram sempre inferiores aos iniciais.

Tabela 17. Absortividade a $232 \mathrm{~nm}$ da farinha de trigo irradiada e armazenada ao ambiente.

\begin{tabular}{ccccc}
\hline \multirow{2}{*}{ Tratamento (kGy) } & \multicolumn{5}{c}{ Tempo (Mës) } \\
\cline { 2 - 5 } & 0 & 1 & 2 & 3 \\
\hline 0 & 2,07 & 1,46 & 1,78 & 1,64 \\
3,5 & 2,85 & 1,41 & 1,68 & 1,35 \\
6 & 2,37 & 1,30 & 1,92 & 1,09 \\
& 2,80 & 1,53 & 2,20 & 1,35 \\
\hline
\end{tabular}

Normalmente se esperaria que com a quebra dos dienos, houvesse um aumento na absortividade em $270 \mathrm{~nm}$. Porém, como parte dos compostos de quebra é volátil, pode ter ocorrido perda deles.

Tabela 18. Absortividade a $270 \mathrm{~nm}$ da farinha de trigo irradiada e armazenada ao ambiente.

\begin{tabular}{ccccc}
\hline \multirow{2}{*}{ Tratamento (kGy) } & \multicolumn{4}{c}{ Tempo (Mès) } \\
\cline { 2 - 5 } & 0 & \multicolumn{1}{c}{1} & \multicolumn{1}{c}{3} \\
\hline 0 & 0,437 & 0,597 & 0,486 & 0,578 \\
3 & 0,2885 & 0,289 & 0,2505 & 0,2796 \\
4,5 & 0,4795 & 0,4865 & 0,4292 & 0,5706 \\
6 & 0,3833 & 0,3217 & 0,2857 & 0,3883 \\
\hline
\end{tabular}

Com a falta de resposta do índice de peróxidos, contava-se que a absortividade acusasse a ocorrência da oxidação, contudo, nota-se que ela ocorreu em escala muito menor àesperada.

A partir de 265 nm são os compostos secundários da oxidação (trienos, aldeídos e cetonas) que apresentam maior absorção, e como pode ser 
verificado na Tabela 18 não houve diferença significativa entre as doses nos tempos.

Tabela 19. Absortividade a $232 \mathrm{~nm}$ do fubá irradiado e armazenado ao ambiente.

\begin{tabular}{cllll}
\hline \multirow{2}{*}{ Tratamento (kGy) } & \multicolumn{5}{c}{ Tempo (Mës). } \\
\cline { 2 - 5 } & 0 & 1 & 2 & 3 \\
\hline 0 & 2,07 & 1,46 & 1,78 & 1,64 \\
3 & 2,85 & 1,41 & 1,68 & 1,35 \\
4,5 & 2,37 & 1,30 & 1,92 & 1,09 \\
6 & 2,80 & 1,53 & 2,20 & 1,35 \\
\hline
\end{tabular}

Tabela 20. Absortividade a $270 \mathrm{~nm}$ do fubá irradiado e armazenado ao ambiente.

\begin{tabular}{cllll}
\hline \multirow{2}{*}{ Tratamento (kGy) } & \multicolumn{4}{c}{ Tempo (Mès). } \\
\cline { 2 - 5 } & 0 & 1 & 2 & 3 \\
\hline 0 & 0,437 & 0,597 & 0,486 & 0,578 \\
4,5 & 0,2885 & 0,289 & 0,2505 & 0,2796 \\
6 & 0,4795 & 0,4865 & 0,4292 & 0,5706 \\
& 0,3833 & 0,3217 & 0,2857 & 0,3883 \\
\hline
\end{tabular}

\subsection{Solubilidade protéica}

A qualidade e integridade da proteína contida em cereais é significativa para o seu valor nutricional. No caso de alguns alimentos como o arroz e o trigo, também é importante para as características funcionais. Altas doses de radiação (30 kGy) não afetam o conteúdo de proteína. No entanto pode ocorrer aumento do teor de aminoácidos livres; pequenos aumentos de isoleucina, tirosina, valina e alanina foram observados em trigo irradiados com doses de 10 kGy (Urbain, 1986).

A solubilidade protéica da farinha de trigo, qualidade da proteína íntegra, que reflete a capacidade de solubilização em meio aquoso, foi de 54\% (Tabela 21). As amostras irradiadas não diferiram significativamente do controle no 
tempo zero e também após três meses de armazenamento, indicando que a irradiação não afetou a solubilidade protéica de farinha de trigo.

Tabela 21. Solubilidade protéica (\%) da farinha de trigo irradiada e armazenada.

\begin{tabular}{ccc}
\hline \multirow{2}{*}{ Tratamento (k Gy) } & \multicolumn{2}{c}{ Tempo (Mès) } \\
\cline { 2 - 3 } & 0 & 3 \\
3 & $54,50^{\mathrm{aA}}$ & $56,05^{\mathrm{aA}}$ \\
4,5 & $53,96^{\mathrm{aA}}$ & $55,14^{\mathrm{aA}}$ \\
6 & $54,02^{\mathrm{aA}}$ & $53,58^{\mathrm{aA}}$ \\
\hline
\end{tabular}

${ }^{\text {AB }}$ letras maiúsculas indicam diferença significativa $p<0,05$ entre as colunas

${ }^{a b}$ letras minúsculas indicam difereça significativa $p<0,05$ entre as linhas

Coeficiente de variação: $5,656 \%$

A solubilidade da proteína do fubá foi de $43 \%$ na amostra original (Tabela 22). A irradiação teve influência negativa sobre a solubilidade, reduzindo-a a valores entre 31,7 e $33,65 \%$ nas amostras recém tratadas. Entretanto o armazenamento afetou gradativamente a integridade das proteínas do fubá não irradiado, tendo ao cabo de seis meses apresentado valores comparáveis aos das amostras irradiadas. Estatisticamente as amostras controle do fubá se apresentaram superiores as demais até o terceiro mês de armazenamento

Tabela 22. Solubilidade protéica do fubá irradiado e armazenado.

\begin{tabular}{cccc}
\hline \multirow{2}{*}{ Tratamento (kGy) } & \multicolumn{3}{c}{ Tempo (Mës) } \\
\cline { 2 - 4 } & 0 & $37,66^{\mathrm{aB}}$ & $32,36^{\mathrm{aC}}$ \\
3 & $42,83^{\mathrm{aA}}$ & $42,28^{\mathrm{bB}}$ & $35,13^{\mathrm{bA}}$ \\
4,5 & $33,17^{\mathrm{bA}}$ & $32,91^{\mathrm{cA}}$ & $40,72^{\mathrm{aB}}$ \\
6 & $31,71^{\mathrm{bA}}$ & $32,66^{\mathrm{cA}}$ & $34,05^{\mathrm{aA}}$ \\
\hline
\end{tabular}

\footnotetext{
${ }^{A B}$ letras maiúsculas indicam diferença significativa $p<0,05$ entre as colunas

${ }^{a b}$ letras minúsculas indicam diferença significativa $p<0,05$ entre as linhas

Coeficiente de variação: $4,77 \%$
} 
Alguns autores sugeriram que a irradiação de trigo resulta em degradação molecular de proteínas (Milner, 1961; Srinivas et al., 1972), contradito por outros trabalhos com trigo e farinha de que a proteína e sua solubilidade não foi afetada pela irradiação (MacArthur \& D'Appolonia, 1983; Fifield et al., 1967).

\subsection{Qualidade tecnológica da farinha de trigo}

\subsubsection{Farinograma}

A qualidade panificável é o atributo de maior importância para a farinha de trigo. Um processo alternativo de conservação deve ter como objetivo manter ou melhorar essas propriedades. Os parâmetros de qualidade de uma farinha panificável são apresentados na Tabela 23.

Tabela 23. Parâmetros farinográficos característicos de farinhas com diferentes forças.

\begin{tabular}{ccccc}
\hline Farinha & ABS(\%) & TDM $(\mathrm{min})$ & $\mathrm{E}(\mathrm{min})$ & $\mathrm{T}$ \\
\hline Fraca & $<55$ & $<2,5$ & $<3$ & $>100$ \\
Média & $54-60$ & $2,5-4,0$ & $3-8$ & $60-100$ \\
Forte & $>58$ & $4,0-8,0$ & $8-15$ & $15-50$ \\
Muito Forte & $>58$ & $>10,0$ & $>15$ & $<10$ \\
\hline
\end{tabular}

Fonte: Pizzinatto (1997)

As farinhas irradiadas apresentaram capacidade de absorver água (ABS\%) aumentada com a dose de irradiação, o que é uma característica desejável para maior rendimento de massa para panificação. A absorção máxima foi atingida com a dose 6 kGy em que se chegou a 65\% (Figura 9).

O aumento da absorção visto como um fato isolado indicaria que a irradiação promoveu uma melhoria da qualidade da massa, pois provoca um 
aumento na quantidade de água acrescida e, conseqüentemente, um ganho de rendimento de massa. Contudo, os outros parâmetros de qualidade não evoluíram nesse sentido. A irradiação promoveu uma alteração no tempo de desenvolvimento da farinha (TDM); sendo assim pode-se dizer que a farinha controle demorou 8,5 minutos para chegar à sua consistência máxima, enquanto que quando as doses aplicadas foram de 3 e 4,5 kGy, o TDM das farinhas diminuiu para 5,5 e 5,4 minutos, respectivamente, indicando uma perda na qualidade desta, mantendo, ainda, a classificação de farinha "forte". Quando a dosagem foi de $6 \mathrm{kGy}$, o TDM foi reduzido a 1,5 minutos, sendo considerada uma farinha "fraca" e não recomendada a sua utilização para panificação (Figura 9), essa redução no TDM é confirmada pelo trabalho de Zaied et al (1996) que utilizando doses de 2, 4 e 8 kGy observou uma redução no tempo de desenvolvimento de massa a partir de 4 kGy.

A estabilidade da farinha é utilizada por algumas empresas como principal padrão de qualidade panificável de uma farinha. A irradiação alterou negativamente a estabilidade da farinha proporcionalmente àdose aplicada. As doses 3 e 4,5 kGy provocaram a redução da estabilidade de 15,7 minutos (controle) para 9,6 e 10,4 minutos, respectivamente. Ainda assim, essas farinhas foram classificadas como "fortes". A dose de irradiação 6 kGy prejudicou a estabilidade, que foi de 1,5 minutos, não sendo recomendada a utilização para a panificação, pois foi classificada como "fraca".

A amostra controle (não irradiada) que apresentava um Índice de Tolerância àMistura (ITM) de 20 UF que a caracterizava como forte, este índice não foi alterada pelos tratamentos 3 e 4,5 kGy que apresentavam o ITM de 30 e 20 UF, respectivamente. O Índice de Tolerância à Mistura (ITM) apresentou valores desfavoráveis à utilização dessa farinha em panificação, quando a dose de irradiação aplicada foi de 6 kGy. O ITM foi de 90 (UF) unidades farinográficas que a classifica como fraca, não sendo possível sua utilização para panificação (Pizzinatto, 1997). 


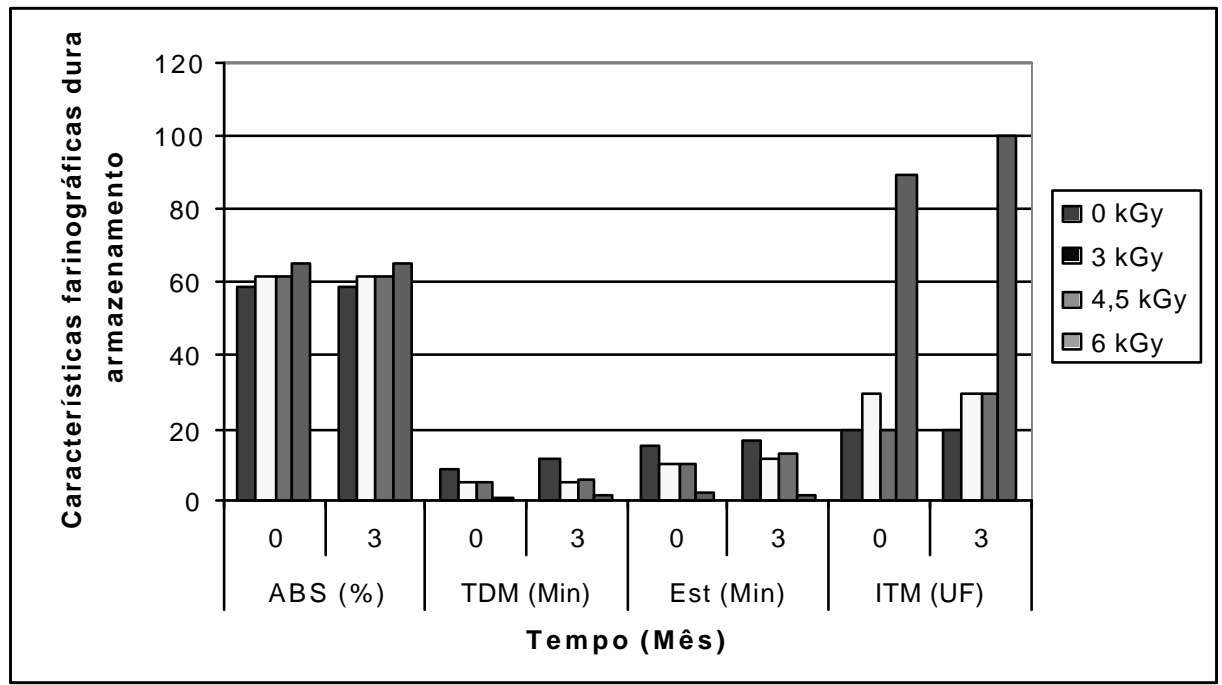

Figura 9 - Parâmetros farinográficos das farinhas de trigo irradiadas e armazenadas ao ambiente no tempo inicial e após três meses.

Após o armazenamento, alguns parâmetros apresentaram uma pequena melhora na qualidade, isso provavelmente acontece devido a uma possível "maturação" da farinha, entretanto não foi suficiente para permitir que as amostras que tiveram uma queda na classificação melhorassem seu desempenho, o que significa que o armazenamento, em termos gerais, não influenciou os parâmetros farinográficos da farinha (Figura 9).

Campa et al. (1965) em seu trabalho não encontraram diferença significativa na capacidade de absorção de água de farinhas irradiadas e não irradiadas. Quando o parâmetro analisado foi o tempo de chegada (D) este diminuiu drasticamente, pois este valor é vinculado ao glúten, obtendo-se em 2000 krad a terça parte do controle. A perda na qualidade do trigo devido à irradiação leva alguns autores a concluir que um trigo que possui características 
tecnológicas de semi-duro passa a ter características de um trigo mole (Campa et al.,1965).

\subsubsection{Alveograma}

Segundo os parâmetros alveográficos, o valor $\mathrm{W}$, que determina a energia de deformação da massa durante o teste e expressa a força da massa, deve ter valores de 250 a 300, para que seja considerado de ótima qualidade de panificação. As amostras que foram irradiadas com 3 kGy não se alteraram pela irradiação, apresentando um $\mathrm{W}$ de 250 , que foi igual ao controle (não irradiada). A farinha, quando foi irradiada com uma dose de 4,5 kGy, apresentou um pequeno aumento na força (260W); uma queda aconteceu quando a dose foi de 6 kGy (190W), estando abaixo dos padrões alveográficos (Figura 10). Resultados anteriores verificados por Campa et al. (1965) indicaram uma queda brusca da força já a partir da dose 300 krad (3 kGy) de irradiação. De 300 (3 kGy) a 2000 krad (20 kGy) houve uma perda de 50\% da força.



Figura 10 - Parâmetros alveográficos das farinhas de trigo irradiadas e armazenadas ao ambiente no tempo inicial e após três meses. 
Como pode ser visto na Figura 10, a tenacidade da massa $(P)$, não foi alterada pela irradiação, as amostras irradiadas apresentaram valores muito próximos. Campa et al. (1965) observaram perda progressiva da tenacidade (P) com a dose de irradiação crescente.

Quanto a extensibilidade (L) da massa, Campa et al. (1965) também verificaram uma perda de forma irregular, conforme a dose de irradiação aplicada. Perdas bruscas ocorreram a partir de $10 \mathrm{kGy}$.

A relação $P / L$ mostra o equilíbrio de uma farinha entre os parâmetros de tenacidade e extensibilidade, com valores ideais entre 0,75 e 1,25. Como a farinha analisada era de alta extensibilidade, a relação $P / L$ era superior à faixa ideal; 1,9 para a farinha controle. Com a irradiação ocorreu um pequeno aumento da tenacidade, que foi reduzido com o incremento da dose de irradiação (Figura 11).

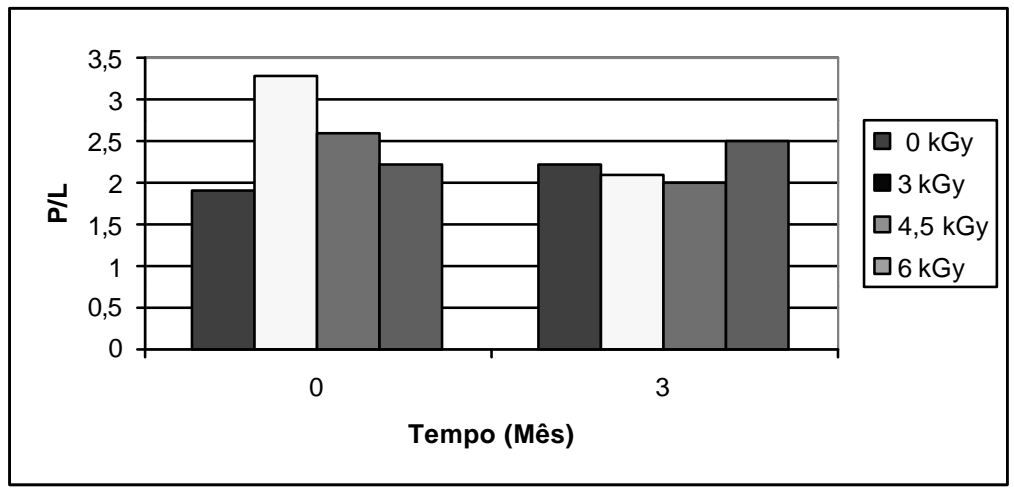

Figura 11 - Relação Tenacidade/ Extensibilidade (P/L) da farinha de trigo irradiada e armazenada ao ambiente no tempo inicial e após três meses.

Quando a farinha foi armazenada por 3 meses, a amostra controle (não irradiada), passou a ter uma energia de deformação de 320W. O tratamento de 3 kGy não apresentou nenhuma alteração na farinha de trigo quanto à energia 
de deformação, sendo igual ao início do experimento (250W). As amostras que foram irradiadas com 4,5 e 6 kGy se alteraram com o armazenamento, apresentando energia de deformação de 230 e 180W, respectivamente.

Em amostras de trigo argentino que sofreram três diferentes tratamentos térmicos (controle, $50^{\circ} \mathrm{C}$ e $140^{\circ} \mathrm{C}$ ), houve danos na energia de deformação, que no controle era de 394 , passou a ser de 374 na amostra tratada a 50드. e de 227 na amostra tratada a $140^{\circ} \mathrm{C}$. O armazenamento acentuou a perda. De um W inicial de 304 , passaram a ter $W$ de 242,190 e 120, respectivamente para os tratamentos após três meses.

\subsection{3 "Falling number"}

Normalmente a farinha de trigo boa para panificação tem um valor de "falling number" entre 200 e 300 segundos (Pizzinatto, 1997).

O método do índice de queda, também chamado de "falling number", é o método mais rápido e adequado para determinar a atividade da $\alpha$-amilase (Pizzinatto, 1997).

A amostra controle apresentou um "falling number" de 320 segundos (Figura 12), valor considerado um pouco acima do ideal, possivelmente devido ao fato da farinha haver sido moída pouco tempo antes do início do experimento, apresentando uma baixa atividade da $\alpha$-amilase. Com esse tempo de "falling number", teoricamente o pão apresentaria volume reduzido e miolo seco. Quando a farinha foi submetida ao tratamento de 3 kGy de irradiação, o "falling number" foi de 254 segundos, na faixa ótima de atividade de $\alpha$-amilase para produzir pães com bom volume e miolo de boa textura. O mesmo aconteceu com a farinha que foi irradiada com 4,5 kGy, que obteve um "falling number" de 259 segundos. Entretanto quando a amostra foi irradiada com 6,0 kGy, o "falling number" foi de 147 segundos, valor de baixa atividade de $\alpha$ amilase, que produz pães pesados com baixo volume, miolo úmido e pegajoso. 


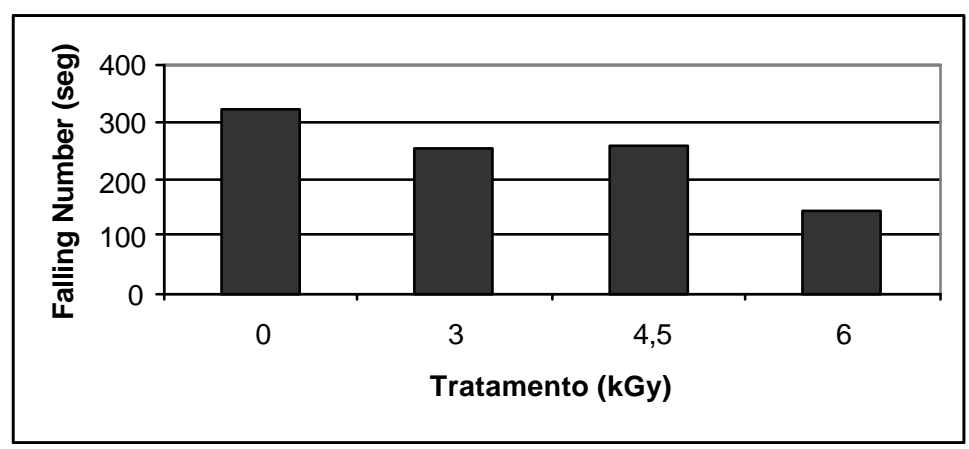

Figura 12 - "Falling number" das farinhas de trigo irradiadas.

Como pode ser observado na Figura 12, a irradiação afetou a atividade da $\alpha$-amilase da farinha de trigo. Entretanto, mesmo nos tratamentos até 4,5 kGy, a alteração ainda permitiu que a farinha fosse classificada como na faixa ótima de $\alpha$-amilase. A utilização de doses superiores a 6 kGy alteram a atividade de $\alpha$-amilase, não sendo aconselhável a utilização dessa farinha para panificação.

\subsubsection{Teste de panificação (produção de pão francês)}

O teste de panificação é usado como teste decisivo para a avaliação do desempenho da farinha (Pratt Jr, 1978). Apesar de ser um teste subjetivo, o prático consegue fazer avaliações seguras sobre a eficiência da farinha na panificação.

A Figura 14 apresenta uma fatia de cada pão francês produzida com cada uma das farinhas. Como se pode verificar a farinha de trigo controle (não irradiada) apresentou uma excelente qualidade panificável, recebendo nota 10 (Ótima) nos parâmetros abertura de pestana e cor da crosta, e nos demais a nota 8 (Bom), alcançando uma pontuação total de 84,62 (Tabela 24) 
Tabela 24. Índice de qualidade da farinha tratamento controle (não irradiada) para o pão francês.

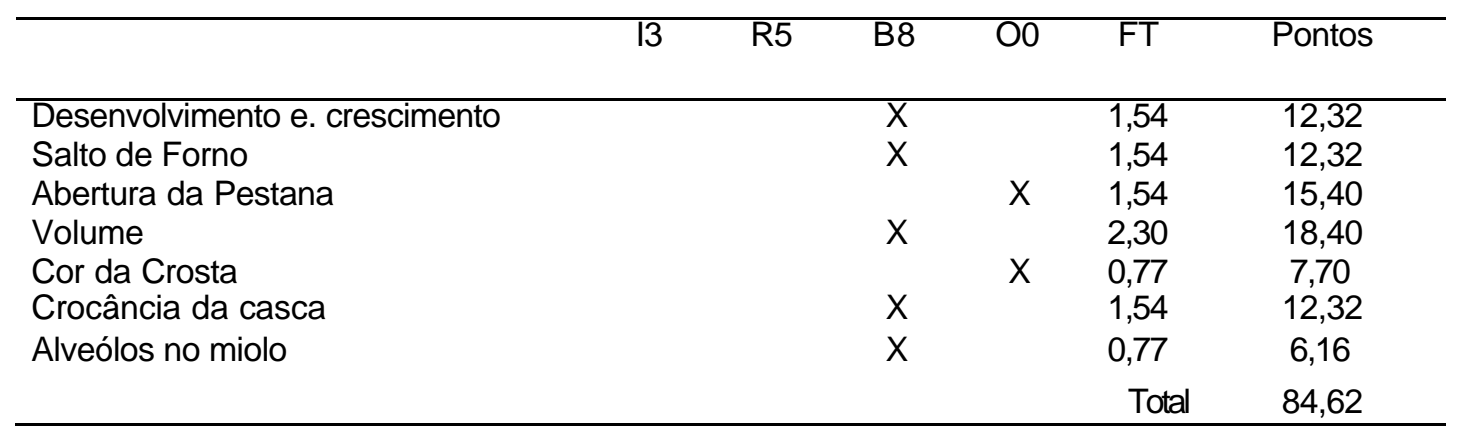

Quando o tratamento aplicado foi de $3 \mathrm{kGy}$, a farinha apresentou uma perda de qualidade quanto à abertura de pestana e cor da crosta, entretanto a nota atribuída a todos os parâmetros foi 8 (Bom), obtendo um total de 80 pontos e, sendo ainda considerada excelente para a panificação (Tabela 25).

Tabela 25. Índice de qualidade da farinha irradiada com 3 kGy para o pão francês.



O tratamento de 4,5 kGy prejudicou o desempenho da farinha de trigo nos parâmetros de salto de forno, abertura de pestana e volume, sendo que as notas atribuídas a estes foram 5 (Ruim); os demais parâmetros não foram alterados pelo aumento da dose. A farinha de trigo que recebeu 4,5 kGy de irradiação não apresentou qualidade panificável, tendo alcançado uma pontuação total de 63,86 (Tabela 26) 
Tabela 26. Índice de qualidade da farinha irradiada com 4,5 kGy para o pão francês.



A farinha de trigo que recebeu 6 kGy de irradiação teve suas características panificáveis prejudicadas. Os únicos parâmetros que não foram afetados pela irradiação foram o desenvolvimento da massa no crescimento e a cor da crosta. Isso se deve aos açúcares redutores produzidos durante 0 processo de irradiação que possivelmente tenham tido efeito positivo na fermentação e na caramelização da cor crosta (Marathe et al., 2002). A pontuação total obtida por esse tratamento foi de 44,63 , sendo considerada insuficiente para uso na produção de pães (Tabela 27).

Tabela 27. Índice de qualidade da farinha irradiada com 6 kGy para o pão francês.

\begin{tabular}{|c|c|c|c|c|c|c|}
\hline & 13 & $\mathrm{R} 5$ & B8 & $\mathrm{OO}$ & FT & Pontos \\
\hline Desenvolvimento e Crescimento & & & $\mathrm{x}$ & & 1,54 & 12,32 \\
\hline Salto de Forno & $x$ & & & & 1,54 & 4,62 \\
\hline Abertura da Pestana & $\mathrm{X}$ & & & & 1,54 & 4,62 \\
\hline Volume & $\mathrm{X}$ & & & & 2,30 & 6,90 \\
\hline Cor da Crosta & & & $x$ & & 0,77 & 6,16 \\
\hline Crocância da casca & & $\mathrm{X}$ & & & 1,54 & 7,70 \\
\hline \multirow[t]{2}{*}{ Alveólos no miolo } & $x$ & & & & 0,77 & 2,31 \\
\hline & & & & & Total & 44,63 \\
\hline
\end{tabular}

No escore total do índice de qualidade (Tabelas 24, 25, 26 e 27), a farinha do tratamento $3 \mathrm{kGy}$ sofreu um decréscimo de 5,45\% comparado à amostra controle. No tratamento de 4,5 kGy, essa perda de qualidade foi muito maior, de 
24,53\%. A maior perda ocorreu no tratamento 6 kGy que sofreu uma redução de $52,74 \%$, do índice de qualidade comparado ao controle.

Os efeitos da irradiação em cada parâmetro do teste de panificação podem ser visualizados na Figura 13.



Figura 13 - Parâmetros de panificação das farinhas de trigo irradiadas .

Como pode ser observado na Tabela 28, o volume específico dos pães foi reduzido pela utilização do tratamento de irradiação, e essa redução foi gradativa com o aumento da dose.

Urbain (1986) encontrou variação no volume específico de pães somente quando as doses foram superiores a $500 \mathrm{krad}$ ( $5 \mathrm{kGy}$ ), a partir da qual ele começou a diminuir gradualmente. A perda do volume chegou a $15 \%$ quando as doses chegaram a 6 kGy. Lee (1959) verificou um decréscimo de 18,75\% no volume do pão produzido com farinhas irradiadas com doses entre 0,25 e 1 Mrad (0 e 10 kGy).

Tabela 28. Volume específico dos pães.

\begin{tabular}{llccc}
\hline Tratamentos $(\mathrm{kGy})$ & 0 & 3 & 4,5 & 6 \\
\hline Volume específico $\left(\mathrm{cm}^{2} / \mathrm{g}\right)$ & 9 & 8,5 & 7,25 & 6,25 \\
\hline
\end{tabular}




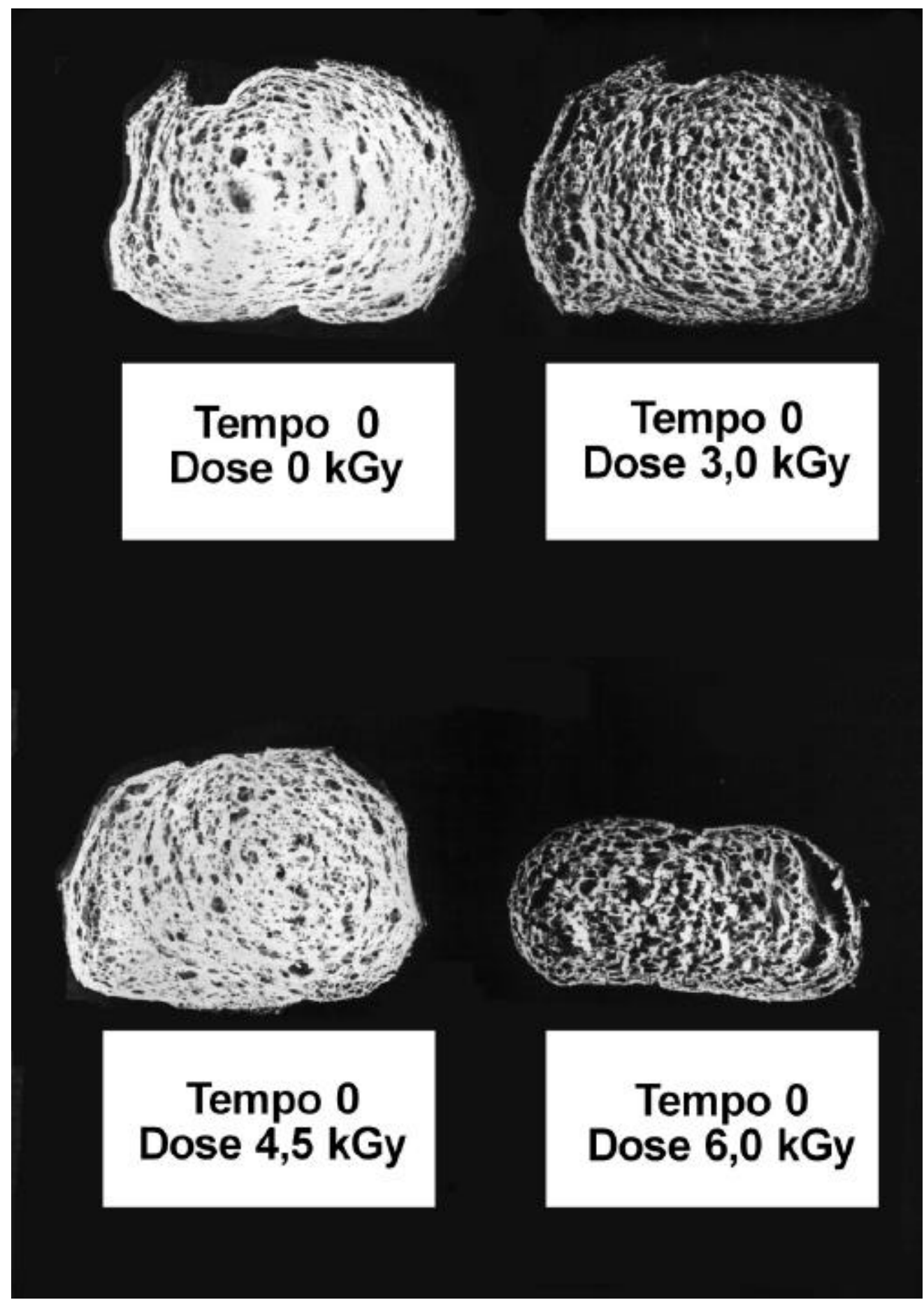

Figura 14 - Pães produzidos com farinhas de trigo irradiadas e armazenados. 
O rendimento da massa modelada aumentou conforme a dose aplicada (Tabela 29), provavelmente devido ao aumento da capacidade absorvida absorção de água observada no farinograma (item 4.9.1).

O aumento no rendimento da massa modelada se reflete no aumento do número dos pães que foram produzidos com a farinha irradiada (Tabela 29). Apesar da farinha tratada ter absorvido mais água, durante o forneamento elas perderam mais umidade.

Tabela 29. Rendimento na produção de pão francês.

\begin{tabular}{lcccc}
\hline \multirow{2}{*}{ Parâmetros } & \multicolumn{4}{c}{ Tratamentos (kGy) } \\
\cline { 2 - 5 } & 0 & 3 & 4,5 & 6 \\
\hline Peso da massa modelada (g) & 3310 & 3320 & 3324 & 3336 \\
Peso do pão (g) & 52 & 52 & 54 & 54 \\
Perda de umidade (\%) & 21,9 & 21,9 & 18,9 & 18,9 \\
Rendimento por 50 kg de farinha (pães) & 1242 & 1246 & 1247 & 1252 \\
\hline
\end{tabular}

Urbain (1986) citou que alguns cereais submetidos a altas doses (3-5 kGy) de radiação podem ter suas características sensoriais, assim como as suas propriedades funcionais alteradas. Um exemplo foi a fabricação do pão fermentado que exige da farinha determinadas características funcionais. Com o aumento das doses, ocorreu uma diminuição da qualidade dos pães, os alvéolos do miolo tenderam a diminuir de tamanho, o miolo e a crosta escureceram principalmente acima de $500 \mathrm{krad}$ (5 kGy). Acima de $200 \mathrm{krad}$ (2 kGy) ocorreu uma perda das propriedades tensoelásticas do glúten.

Baixas doses de radiação gama como 20.000 - 150.000 rad $(0,2-1,5$ kGy) produzem um máximo nas curvas de viscosidade do amido, gera substâncias capazes de causar a precipitação por eletrolise, solubilização de gliadina e o aumento do "falling number". Esta anomalia explica a melhoria nas propriedades de panificação que certos autores notaram em casos de baixas doses de radiação em farinhas de trigo (Deschreider, 1965). 


\subsection{Análise sensorial}

\subsubsection{Aparência global}

O tratamento afetou a aparência global da farinha de trigo e do fubá, proporcionalmente ao aumento da dose de irradiação e ao tempo de armazenamento.

O atributo aparência global não foi lembrado em nenhuma ficha sensorial para indicar o desagrado pela amostra, entretanto analisando as freqüências das notas do fubá (Figuras 15, 16, 17, e 18) percebe-se que durante os primeiros meses de armazenamento houve uma maior freqüências das expressões "gostei extremamente" e "gostei muito" (notas 8 e 7), sendo que a freqüência destas notas foi reduzida ao longo do armazenamento. As notas mais baixas ("desgostei muito" e "desgostei extremamente") foram mais freqüentes a partir do $5^{\circ}$ mês de armazenamento.

O tratamento de 3 kGy (Figura 16) de irradiação comparado ao controle (Figura 15) pouco afetou a aparência global da farinha de trigo.

As farinhas que receberam 4,5 e $6 \mathrm{kGy}$ foram as que apresentaram uma maior freqüência de notas baixas, sendo assim as mais rejeitadas pelos provadores

O fubá apresentou em geral uma redução na freqüência das notas altas conforme a dose de irradiação aplicada (Figura 19, 20, 21 e 22).

Apesar dos provadores não terem notado grandes alterações neste parâmetro na farinha de trigo, a irradiação afetou a sua aparência global, e essa alteração foi aumentada progressivamente àdose aplicada. 


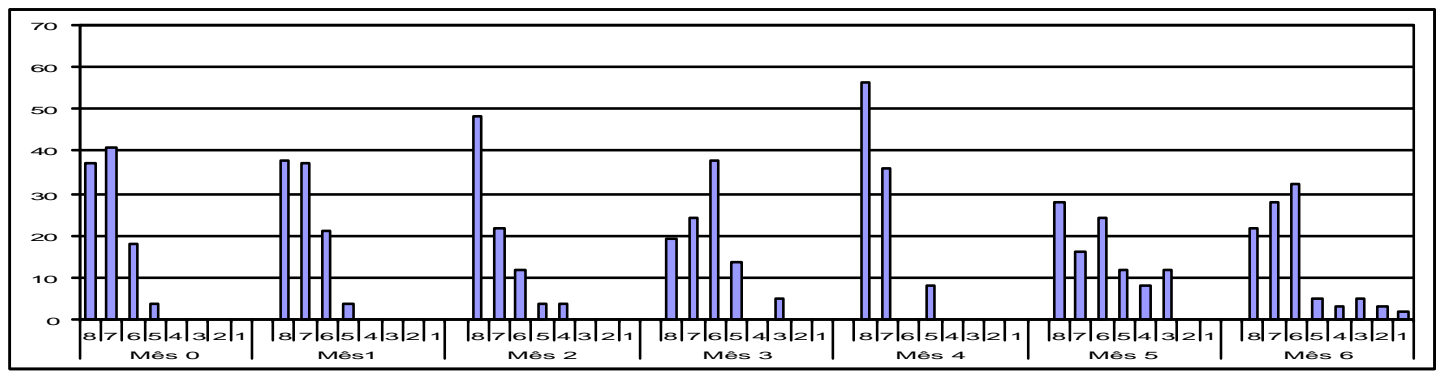

Figura 15 - Freqüência (\%) das notas de aparência do fubá irradiado (controle) durante o armazenamento.

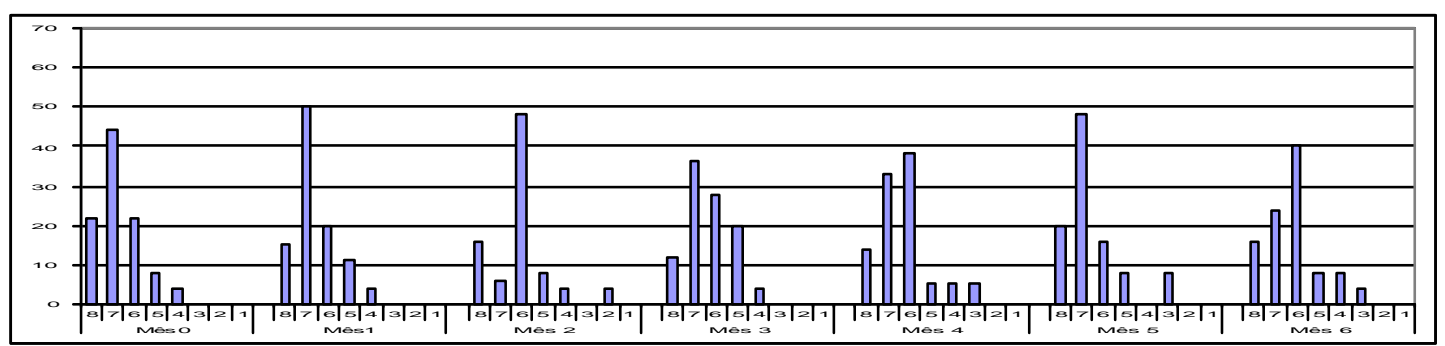

Figura 16 - Freqüência (\%) das notas de aparência do fubá irradiado (3 kGy) durante o armazenamento.



Figura 17 - Freqüência (\%) das notas de aparência do fubá irradiado (4,5 kGy) durante o armazenamento.

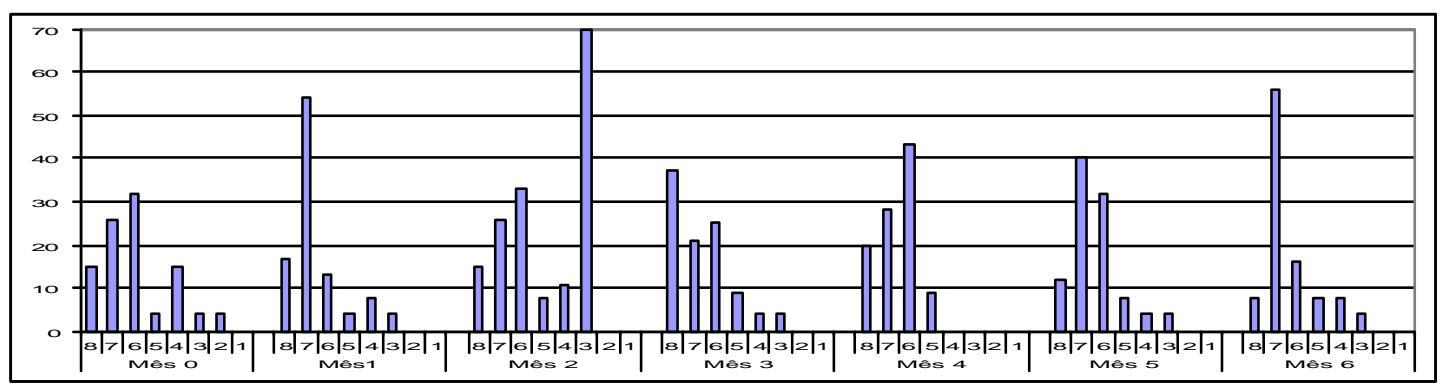

Figura 18 - Freqüência (\%) das notas de aparência do fubá irradiado (6 kGy) durante o armazenamento. 


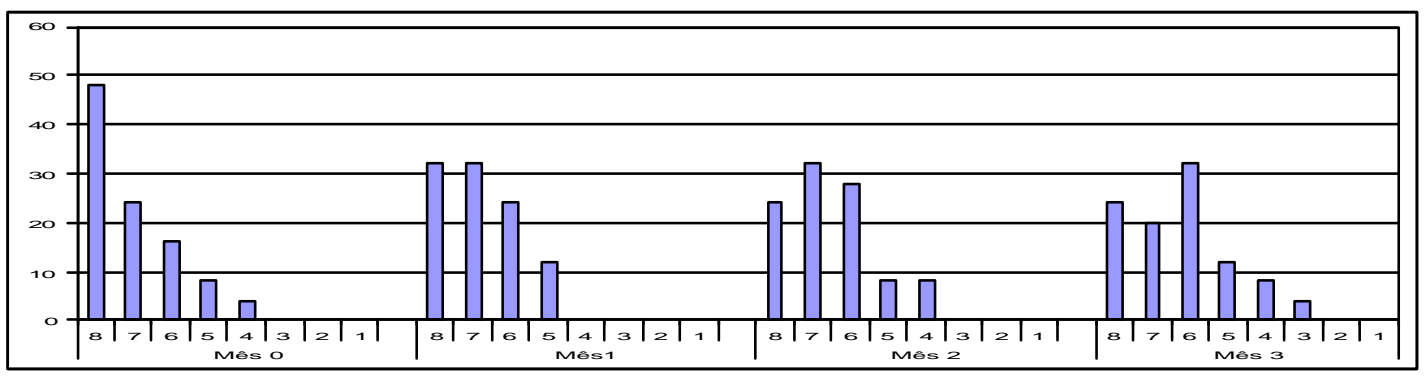

Figura 19 - Freqüência (\%) das notas de aparência da farinha de trigo irradiada (controle) durante o armazenamento.



Figura 20 - Freqüência (\%) das notas de aparência da farinha de trigo irradiada (3 kGy) durante o armazenamento.

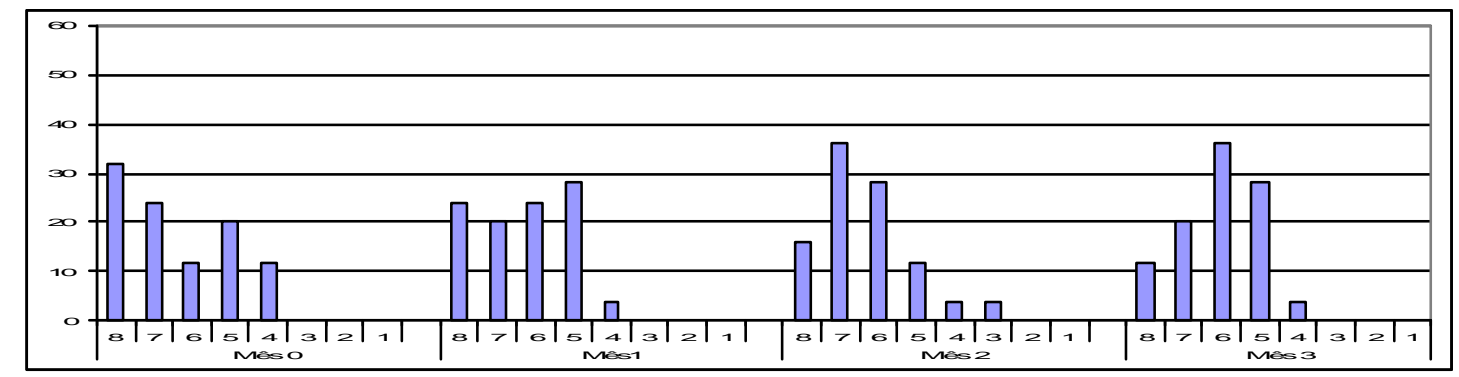

Figura 21 - Freqüência (\%) das notas de aparência da farinha de trigo irradiada (4,5 kGy) durante o armazenamento.

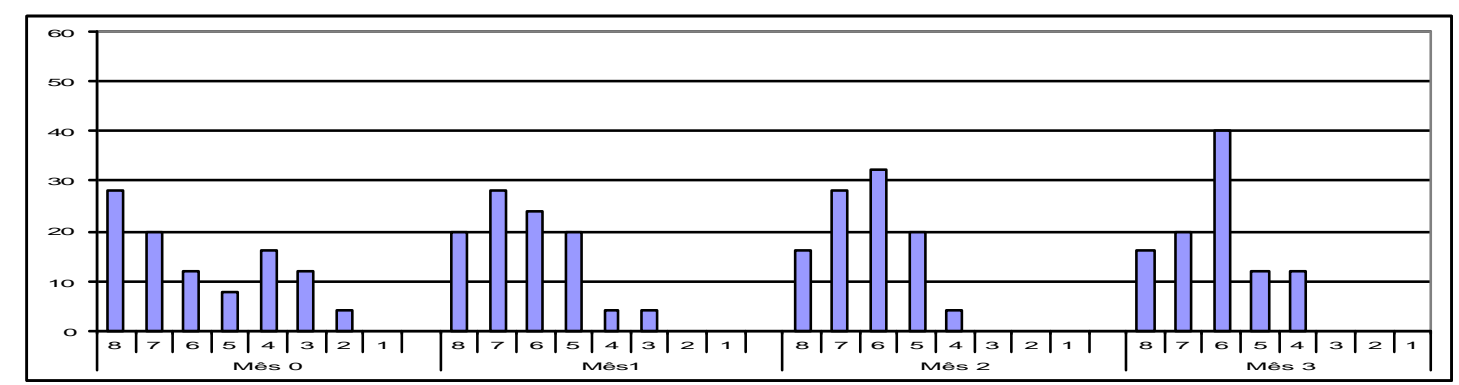

Figura 22 - Freqüência (\%) das notas de aparência da farinha de trigo irradiada (6 kGy) durante o armazenamento. 


\subsubsection{Cor}

A cor é um fator importante de aceitação da farinha de trigo e do fubá.

Os provadores, em æus comentários na análise sensorial, citaram como sendo este um dos motivos da rejeição das amostras de farinha de trigo desde o início do experimento. A justificativa utilizada foi o escurecimento da farinha, que pode ser confirmada pela análise de cor objetiva no item 4.2.

O fubá apresentou alterações em sua coloração devido ao tratamento de irradiação e, assim como na farinha de trigo, essas alterações foram perceptíveis aos provadores que mencionaram na ficha sensorial o clareamento das amostras de fubá, e que pode ser confirmada pela análise de cor objetiva no item 4.2. Lai et al., (1959) e Tipples e Norris (1965) que estudaram os efeitos da radiação nos componentes carotenóides dos alimentos também haviam observado esse comportamento (Figura 23, 24,25 e 26).

Os tratamentos 4,5 e 6 kGy provocaram uma queda nas freqüências de notas altas da farinha de trigo, o que indica que a irradiação nestas dosagens causou uma maior rejeição quanto à cor das amostras. (Figuras 28, 29, 30 e 31) 


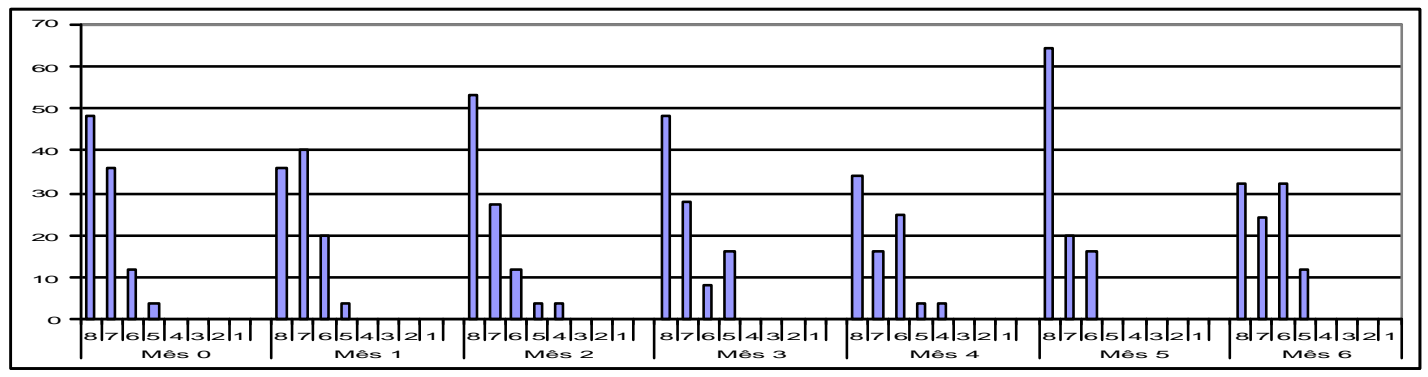

Figura 23 - Freqüência (\%) das notas de cor do fubá irradiado (controle) durante o armazenamento.

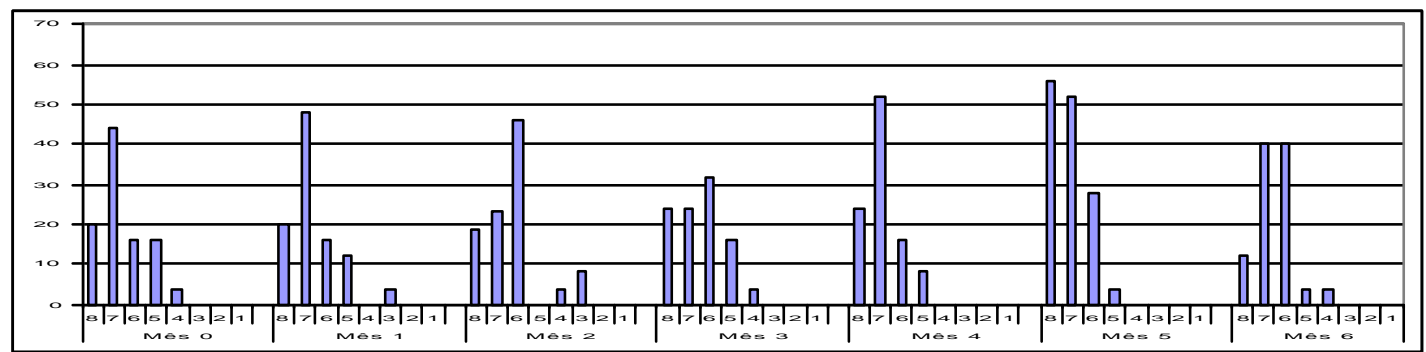

Figura 24 - Freqüência (\%) das notas de cor do fubá irradiado (3 kGy) durante o armazenamento.

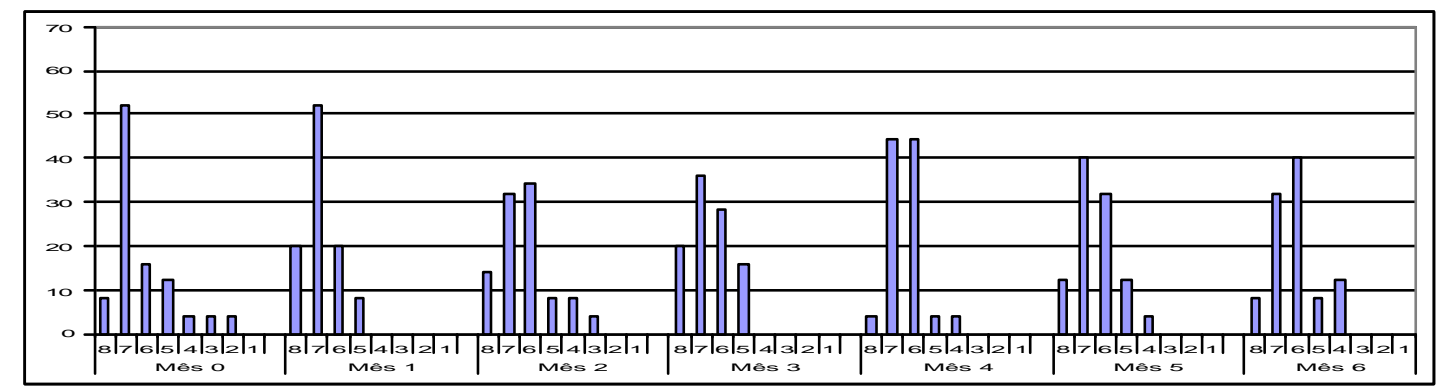

Figura 25 - Freqüência (\%) das notas de cor do fubá irradiado (4,5 kGy) durante o armazenamento.

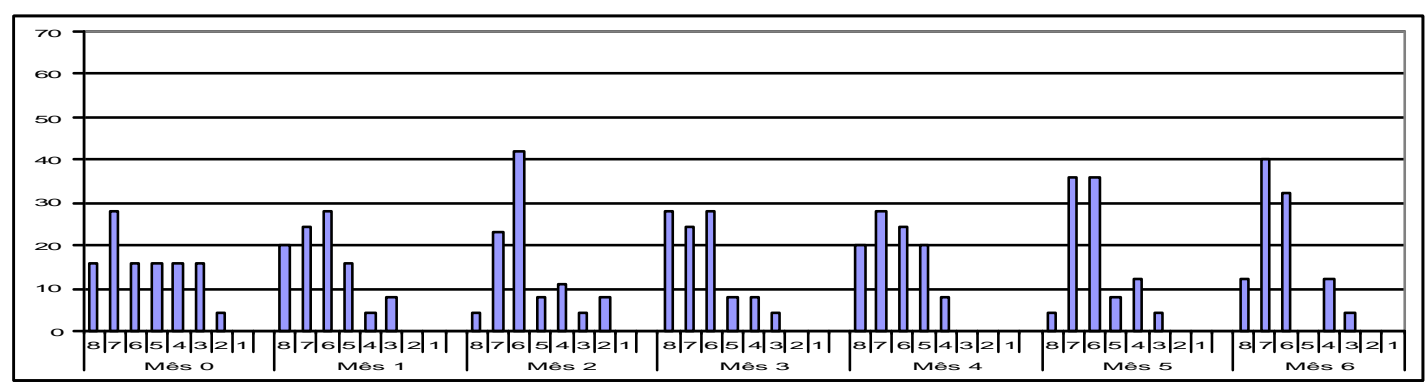

Figura 26 - Freqüência (\%) das notas de cor do fubá irradiado (6 kGy) durante o armazenamento. 


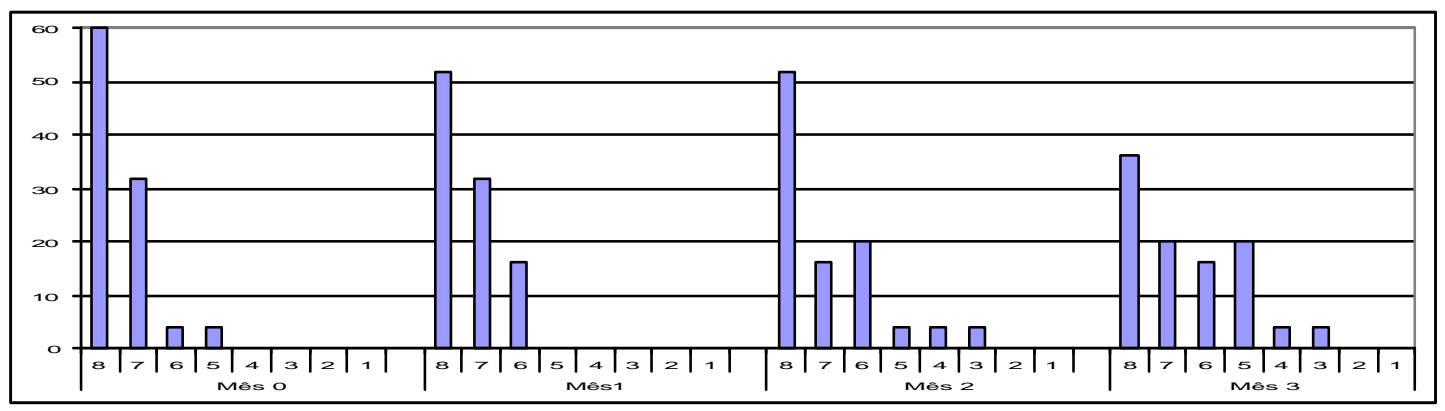

Figura 27 - Freqüência (\%) das notas de cor da farinha de trigo irradiada (controle) durante 0 armazenamento.

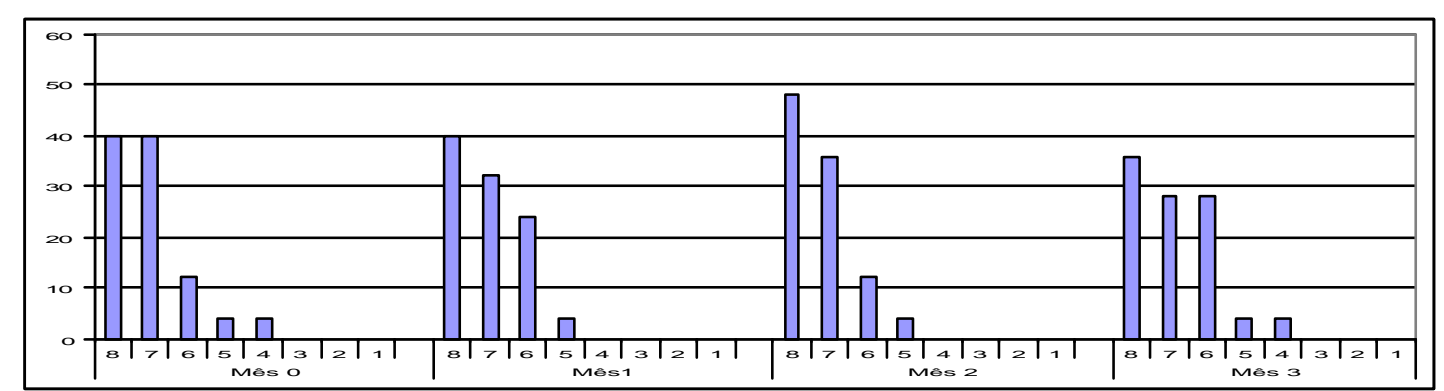

Figura 28 - Freqüência (\%) das notas de cor da farinha de trigo irradiada (3 kGy) durante o armazenamento.

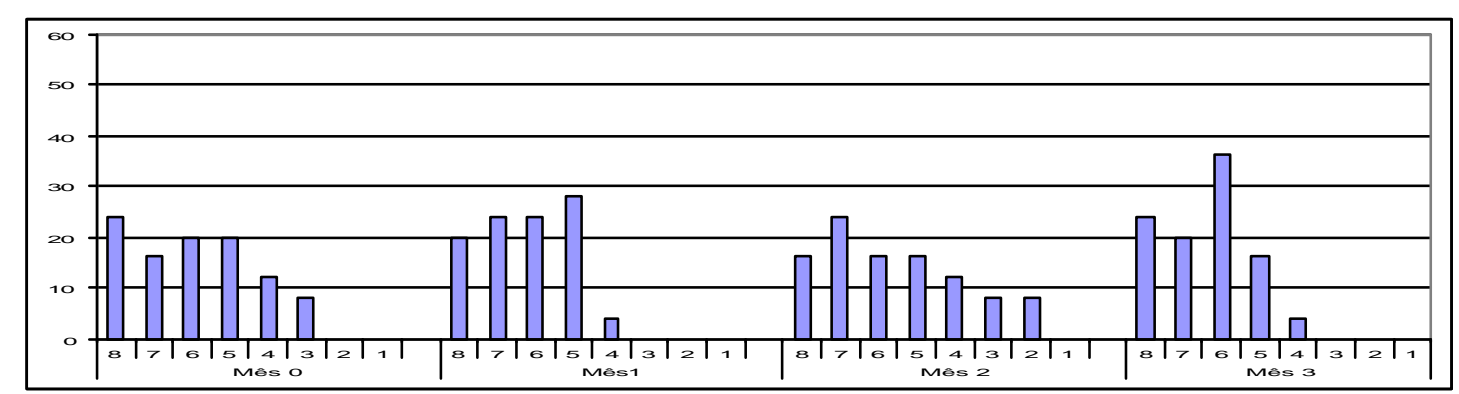

Figura 29 - Freqüência (\%) das notas de cor da farinha de trigo irradiada (4,5 kGy) durante 0 armazenamento.

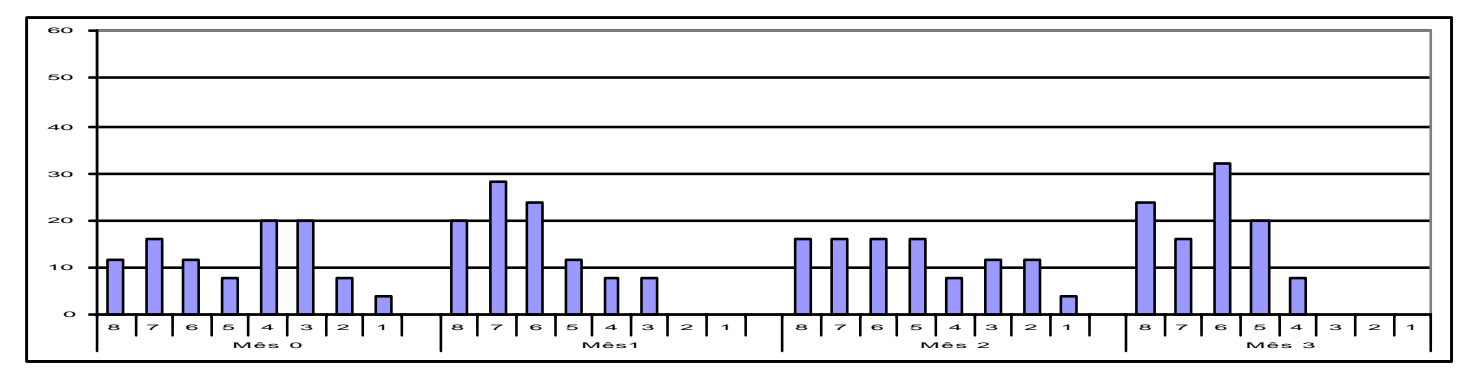

Figura 30 - Freqüência (\%) das notas de cor da farinha de trigo irradiada (6 kGy) durante o armazenamento. 


\subsubsection{Aroma}

O aroma do fubá foi o parâmetro mais citado para justificar o desagrado pelas amostras nos primeiros meses de armazenamento. Os provadores 0 caracterizaram como: "metálico" "velho" e "ardido", entretanto nos últimos meses de armazenamento nenhuma menção foi feita quanto ao aroma. Provavelmente isso ocorra devido ao aumento da acidez observado no item 4.5, que produz compostos que são voláteis e se perderam para o ambiente.

Com o aumento da dose de irradiação a freqüência das notas mais altas (8 e 7) diminuiu, predominando as notas médias e baixas (entre 5 e 2) (Figuras 32, 33, 34 e 35), indicando que amostras que foram irradiadas, sofreram uma maior rejeição pelos provadores.

O aroma da farinha de trigo também causou desagrado aos provadores nos primeiros dois meses de análise e, assim como a fubá com 0 armazenamento esse aroma não característico possivelmente tenha sido volatilizado.

Uma modificação no odor também foi observada por Tipples \& Norris (1965) em amostras de trigo irradiadas (0, 1, 10 e 100 kGy) que apresentaram um forte odor de gordura oxidada, mais intenso com o aumento das doses de irradiação. Esse odor persistiu quando o trigo irradiado foi moído para a fabricação de farinha. Urbain (1986) detectou alteração no odor somente com doses acima de 500krad (5 kGy). Lai et al. (1968) verificaram que o trigo irradiado apresentou um forte odor, o qual foi mais intenso com altos teores de irradiação e persistiu quando o trigo foi moído. 


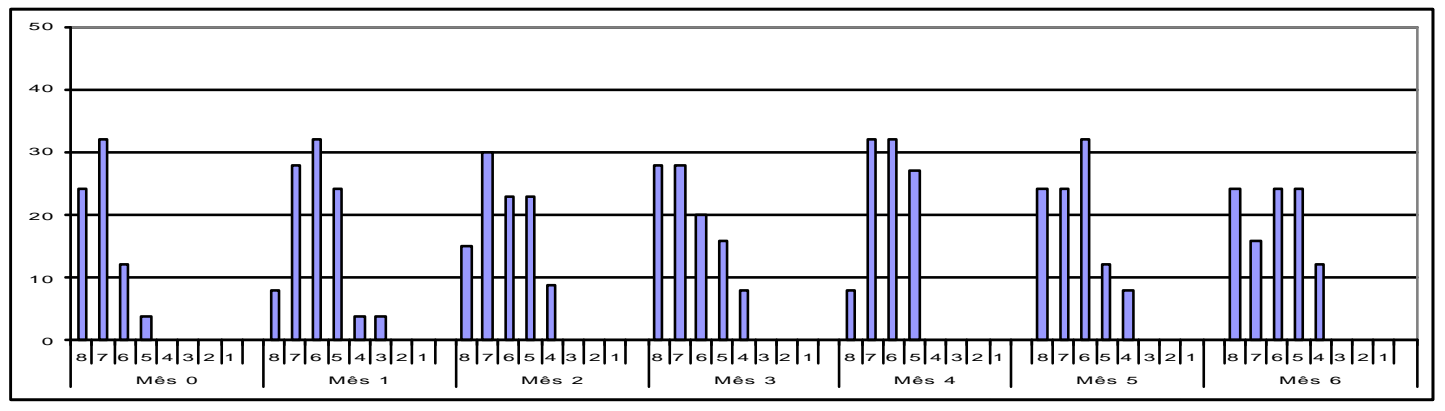

Figura 31 - Freqüência (\%) das notas de aroma do fubá irradiado (controle) durante o armazenamento.

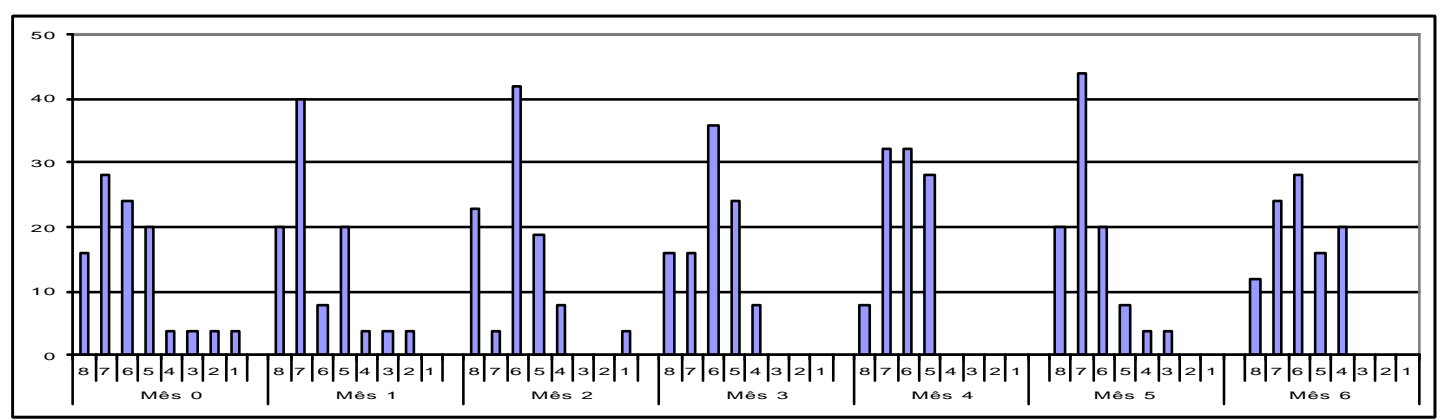

Figura 32 - Freqüência (\%) das notas de aroma do fubá irradiado (3 kGy) durante o armazenamento.



Figura 33 - Freqüência (\%) das notas de aroma do fubá irradiado (4,5 kGy) durante o armazenamento.

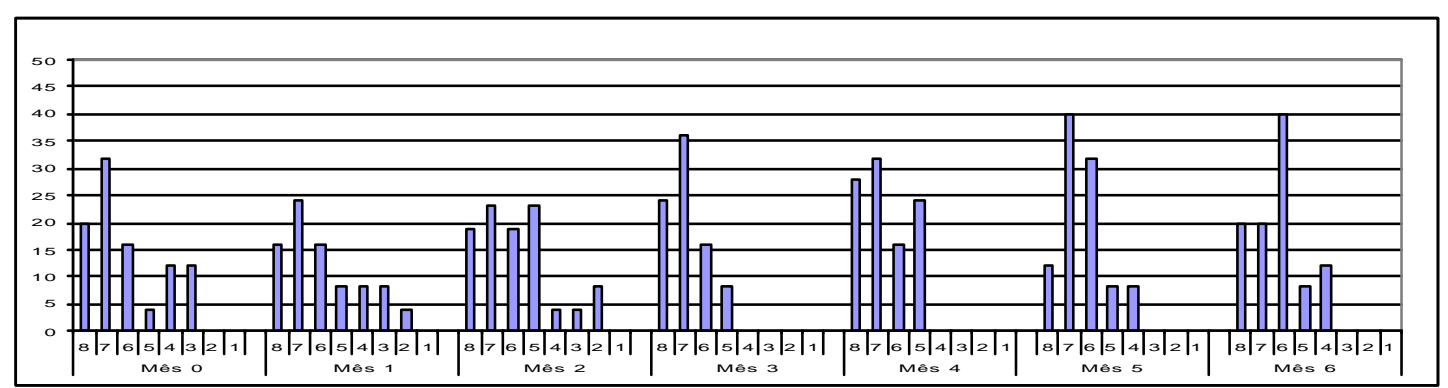

Figura 34 - Freqüência (\%) das notas de aroma do fubá irradiado (6 kGy) durante o armazenamento. 


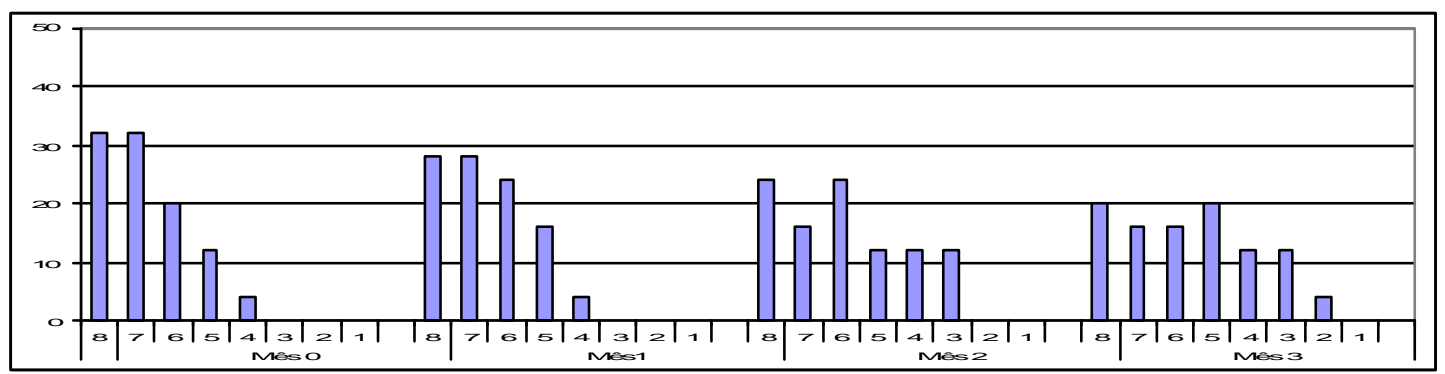

Figura 35 - Freqüência (\%) das notas de aroma da farinha de trigo irradiada (controle) durante 0 armazenamento.

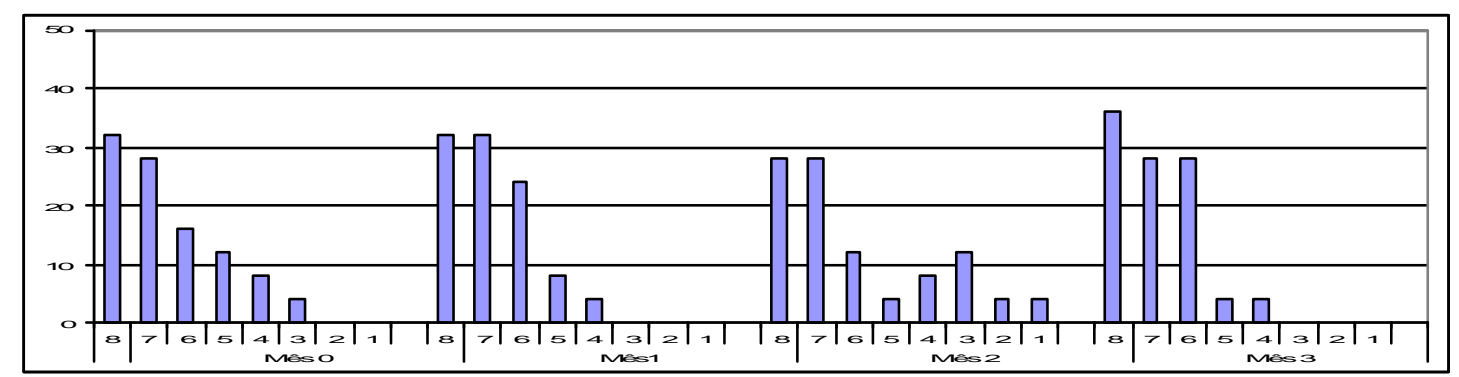

Figura 36 - Freqüência (\%) das notas de aroma da farinha de trigo irradiada (3 kGy) durante 0 armazenamento.

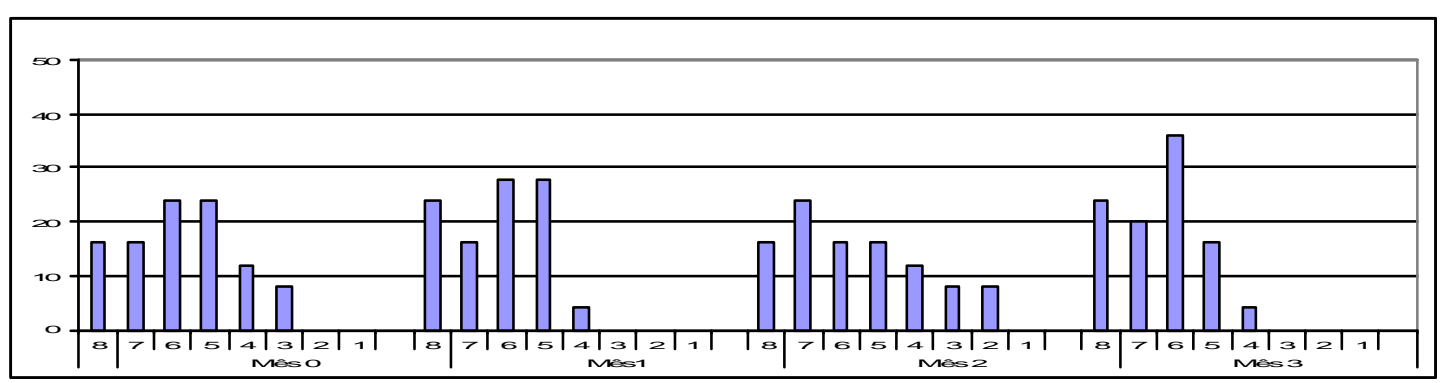

Figura 37 - Freqüência (\%) das notas de aroma da farinha de trigo irradiada (4,5 kGy) durante o armazenamento.



Figura 38 - Freqüência (\%) das notas de aroma da farinha de trigo irradiada (6 kGy) durante o armazenamento. 


\section{CONCLUSÕES}

- O processo de irradiação não afetou a qualidade oxidativa das farinhas de trigo e do fubá dentro do período de validade fornecido pelos fabricantes para produtos semelhantes não irradiados.

- A irradiação afetou a integridade da fração lipídica promovendo sua hidrólise. Os níveis de acidez das farinhas irradiadas foram superiores as do controle. O fubá foi afetado em maior extensão do que a farinha de trigo. $\mathrm{O}$ armazenamento concorreu para o aumento da acidez.

- A fração carboidrato da farinha de trigo e do fubá foi a mais afetada pela irradiação demonstrada através do exame de suas propriedades viscoelásticas.

- A farinha de trigo e o fubá se mostraram aceitáveis sensorialmente em todos os tratamentos, mesmo quando receberam as doses mais altas de 6 kGy, entretanto é possível observar que a irradiação associada ao tempo de armazenamento provocou redução na qualidade das farinhas.

- O tratamento de $3 \mathrm{kGy}$ de radiação pouco alterou a farinha em sua qualidade tecnológica, sendo esta a única dose indicada para a fabricação de pão francês. As doses de 4,5 e 6 kGy não podem ser recomendadas para a farinha de trigo, pois produziriam paes de baixa qualidade. 


\section{REFERÊNCIAS BIBLIOGRÁFICAS}

AGÊNCIA DE VIGILÂNCIA SANITÁRIA - ANVISA. Decreto Lei no $\mathbf{7 2 7 1 8}$ de 29 de agosto de 1973. http://www.anvisa.gov.br/legis/decretos/72718_htm (16 jul. 2003)

AGÊNCIA DE VIGILÂNCIA SANITÁRIA - ANVISA. Resolução no 12 de 24 de julho de 1978. http://www.anvisa.gov.br/legis/resol/12-78_farinhas.htm (12 de jun. 2003)

AGÊNCIA DE VIGILÂNCIA SANITÁRIA - ANVISA. Resolução no 354 de 18 de julho de 1996. http://www.anvisa.gov.br/legis/resol/354_96.htm (21 set. 2002)

AGÊNCIA DE VIGILÂNCIA SANITÁRIA - ANVISA. RDC no 21 de 21 de fevereiro de 2001. http:/www.anvisa.gob.br/legis/resol/218_01re.htm (16 jul. 2003)

ALDRYHIM, Y.N.; ADAM, E.E. Efficacy of gama irradiation against Sithophilus granaries (L.)(Coleoptera:Curculionidae). Journal of Stored Products Research, v.35, p.225-232, 1999.

AMERICAN ASSOCIATION OF CEREAL CHEMISTS. Aproved methods of AACC. 10.ed. St Paul: AACC, 2000. 1200p. 
AMERICAN OIL CHEMISTS' SOCIETY. Official methods and recommended practices of AOCS. 5.ed. Champaign: AOCS, 1997. 3v.

ANATHASWAMY, H.N.; VAKI, V.K.; SREENIVASAN, A. Some physicochemical changes in gamma irradiated wheat. In: SYMPOSION ON BASIC MECHANISMS IN RADIATION BIOLOGY AND MEDICINE, New Delhi, 1971. Proceedings. New Delhi: IAEA, 1971. p.347.

ANON. Adjustment agreed at ninth meeting of the parties relating to the controlled substance. In: MEETING OF THE PARTIES TO THE MONTREAL PROTOCOL ON SUBSTANCES THAT DEPLETE THE OZONE LAYER, 9., Nairobi, 1997. Annex III. Nairobi: United Nation Environment Programme, 1997. $2 \mathrm{p}$.

BAUMAN, H.E.; BAEDER, H.; STEIN, J.A.; HARREL, C.G.; LARSEN, R.A. Effect of gamma irradiation on cake mixes at high and low moisture levels. Food technology, v.11, p.193-196, 1957.

BAILEY, C.H. The changes in flour incidental to aging. In: The chemistry of wheat flour. New York:The Chemical Catalog Co.,1925. cap.8, p.177-193.

BERGER, G.; SAINT-LÉBE, L. Test of the irradiation of corn starch based on the use of 2 thiobarbituric acid. Starke, v.21, n.8, p.205, 1969.

BLIGH, E.G.; DYER, W. J. A rapid method of total lipid extration and purification Canadian Journal of Biochemistry and Physiology, v.37, n.8, p.911-917, 1959. 
BRHUN, C.M.; WOOD, D.B. Position of the American Dietetic Association: food irradiation. Journal of the American Dietetic Association, v.96, n.1, p.6971, 1996.

BYUN, M.W.; KANG, I.J.; KWON, J.H.; HAYASHI, Y.; MORI, T. Physicochemical properties of soybean oil extracted from gama irradiated soybeans. Radiations Physics Chemistry, v.47, n.2, p.301-304, 1996.

CAMPA, J.P.; GABARIN, R.V.A.; PAHISSA, M.H.H.; BASSA, L. Analisis fisicoquimico de trigo irradiado: estudio de sus características germinativas y nutricionales. In: INTERNATIONAL SYMPOSIUM ON FOOD IRRADIATION, Vienna, 1966 Processing. Vienna: International Atomic Energy Agency, 1966. p.355-359.

CIACCO, C.F.; CHANG, Y.K. Tecnologia de massas alimentícias. São Paulo: Secretaria da Indústria, Comércio, Ciência e Tecnologia, 1982. 187p. (Série Tecnologia Agroindustrial, 8)

CIESLA, K.; ZOLTOWSKI, T.; MOGILEVSKY, L.Y. Detection of starch transformation under gamma irradiation by small-angle $\mathrm{X}$-rays scattering. Starch/Staerke, v.43, p.11, 1991.

CHUNG, O.; FINNEY, K.F.; POMERANZ, Z.Y. Lipids in flour from gamma irradiated wheat. Journal of Food Science, v.32, p.315, 1967.

COGBURN, R.R.; TILTON, E.W.; BROWER, J.H. Bulk-grain gama irradiation for control of insects infecting wheat. Journal of Economic Entomology, v.63, p.818-821, 1972. 
CORWELL, P.B. The entomology of radiation desinfestation of grain. In: URBAIN, W.M. Food irradiation. Orlando: Academic Press Inc., 1986. cap.1, p.52-55, 74-78.

DAFTARY, R.D.; POMERANZ, Y. Changes in lipid composition in maturing wheat. Journal of Food Science, v.30, p.577, 1965.

DELINCEE, H. Recent advances in radiation chemistry of lipids. In: ELIAS, P.S.; COHEN, A.J. Recent advances In food irradiation. Amsterdan: Elsevier Biomedical Press, 1983. cap.3, p.89.

DESCHREIDER, A.R. Acton des rayons gama sur les elements constitutifs de la farine de ble. In: INTERNATIONAL SYMPOSIUM ON FOOD IRRADIATION, Vienna, 1966. Processing Vienna: International Atomic Energy Agency, 1966. p.643-648.

DESCHREIDER, A.R. Chages in starch and its degradation products on irradiating wheat flour with gamma rays Starch/Staerke, v.12, p.197, 1960.

DIAS FILHO, M.; BERNARDES, B. Novo processo de conservar produtos alimentares. Latino Americana, v.9, n.4, p.1-7, 1988.

EGGUM, B.O. The nutritional value of rice in comparison with other cereals. In: WORKSHOP ON CHEMICAL ASPECTS OF RICE GRAIN QUALITY, Philippines, 1959. Proceedings. Philippines: AACC, 1959. p.91-111.

EL-DASH, A.A.; CAMARGO, C.O.; DIAZ, N.M. Fundamentos da tecnologia de panificação. São Paulo: Secretaria da Industria, Comércio, Ciência e Tecnologia, 1982. 349p. (Série Tecnologia Agroindustrial) 
EMULZINT ADITIVOS ALIMENTARES INDUSTRIA E COMÉRCIO. Apostila de panificação. Campinas: ITAL, 1985. 89p.

EVANGELISTA, C.M. Análise espectofotométrica da fração lipídica de grãos de soja [glycine $\max (L)$ Merril macerados. Piracicaba, 1996. 70p. Tese (Mestrado) - Escola Superior de Agricultura "Luiz de Queiroz", Universidade de São Paulo.

FAO. Division of nuclear techniques in food and agriculture. Vienna, 1991. $7 p$.

FARKARS, J. ANDRÁSSY, É. Decrease of bacteria spoilage of bread by lowdose irradiation of its flour. In: INTERNATIONAL ATOMIC ENERGY AGENCY. Combination process in food irradiation. Vienna: IAEA, 1981. p.81-94.

FAUST, M.; MASSEY, L.M. The effect of ionizing radioation on starch breakdown in barley endosperm. Radiation Research, v.29, p.33, 1966.

FIFIELD, C.C.; GOLUMBIC, C.; PEARSON, J.L. Effect of gamma-irradiation on the biochemical, storage and bread making properties of wheat. Cereal Science Today, v.12, p.253-257, 261-262, 1967.

GERMANI, R.; BENASSI, V.T.; CARVALHO, J.L.; WATANABE, E.; CAMPOS, J.E.; CARVALHO, C.W.P. Curso de controle da qualidade tecnológica do grão e da farinha de trigo. Rio de Janeiro: EMBRAPA, 1997. 60p.

GRANT, L.A.; D'APPOLONIA, B.L. Effect of low level gamma radiation on water-soluble non-starchy polysaccharides isolated from hard red spring wheat flour and bran. Cereal Chemistry, v.68, p.651, 1991. 
GUTKOSSKI, L.C.; PEDÓ, I. Aveia: composição química, valor nutricional e processamento. São Paulo: Varela, 2000.192p.

HAFEZ, Y.S.; MOHAMED, A.I.; SINGH, G.; HEWEDY, F.M. Effect of gamma irradiation on proteins and fatty acids of soybean. Journal of Food Science, v.50, p.1271, 1985.

HANIS, T.; MNUKOVA, J.; JELEN, P.; KLIR, P.; PEREZ, B.; PEREZ, H. Effect of gamma irradiation on survival of natural microflora and some nutrients in cereal meals. Cereal Chemistry, v.651, p.381-383, 1988.

HANIS, T.; MUNKOVA, J. Radiation and heat induced changes in content (FAO contents of vitamin $A$ and acid and peroxide values) in cereal-based mixtures during storage. In: INTERNATIONAL CONFEDERATION FOOD SCIENCE TECHNOLOGICAL, Manilla, 1985. Proceedings. Manilla: IAEA, 1985. $24 p$.

HARTUNG, T.E; BULLERMAN, L.B.; ARNOLD, R.G.; HEIDELBAUGH, N.D. Application of low dose irradiation to a fresh bread system for space fights. Journal of Food Science, v.38, p.129-132, 1973.

HARA, A.; RADIN, N.S. Lipid extraction of tissues with a low-toxicity solvent. Analitical Biochemistry, n.90, p.420-426, 1978.

INTERNATIONAL ATOMIC ENERGY AGENCY FOOD AND ENVIRONMENTAL PROTECTION. Newsletter, v.1, n.2, p.1, 1998. Supplement.

INSTITUTO BRASILEIRO DE GEOGRAFIA E ESTATÍSTICA - IBGE. Produção agrícola 2003. 2003 http://www.ibge.gov.br (10 jun 2003) 
INSTITUTE OF FOOD TECNOLOGISTS. Effects of food processing on nutritive values: a scientific status summary by the Institute of Food Technologists' expert panel on food safety and nutrition and the Committee on Public Information. Food Technology, v.40, n.12, p.109-116, 1983.

INTERNATIONAL UNION OF PURE AND APPLIED CHEMISTRY - IUPAC. Standard methods for the analysis of oils, fats and derivatives. 6.ed. Washington: IUPAC, 1979. 659p.

IRRADIATION in the production and handling of food. Federal Register, v.51, p.133375-13799, 1986.

JAY, J.M. Microbiologia moderna de los alimentos. Zaragoza: Acribia, 1992. $804 p$.

JEFFERIES, D.J.; BANHAN, E.J. The effect of dose rate on the responses of Tribolium confusum Duv., Oryzaephilus surinamensis L. and Sithophilus granarius L. to "Co gama irradiation". In: CORNWEL, P.B. Entomology of radiation desinfestation of grain. Oxford: Pergamon Press, 1966. cap.4, p.178-186.

KANG, I.J.; BYUN, M.W.; YOOK, H.S.; BAE, C.H.; LEE, H.S.; KWON, J.H.; CHUNG, C.K. Production of modified starches by gamma irradiation Radiation Physics and Chemistry, v.54, p.425-430, 1999.

KENT-JONES, D.W.; AMOS, A.J.; MARTIN, W. Experiments in the photoelectric recording of flour grade by measurements of reflecting power. Analyst, v.75 p.133-142, 1950. 
KÖKSEL, H.; SAPIRSTEIN, H.D.; CELIK, S.; BUSHUK, W. Effects of gamma irradiation of wheat on gluten proteins. Journal of Cereal Science, v.28, p.243-250, 1998.

LAI, S.P., FINNEY, K.F; MILNER, M. Treatment of wheat with ionizing radiations and. oxidative, physical, and biochemical changes. Cereal Chemistry, v.36, p.401-411, 1959.

LEE, C.C. The baking quality and maltose value of flour irradiated with $\mathrm{CO}^{60}$ gamma rays. Cereal Chemistry, v.36, p.70, 1959.

LEITÃO, R.F.F.; GOLÇALVES, J.R.; EIROA, M.N.U.; GARCIA, E.E.C. Tecnologia do macarrão: manual técnico. Campinas: ITAL, 1990. 71p. v.5.

LORINI, I. Avaliação do produto INSECTO no controle de pragas de trigo armazenado. In: REUNIÃO NACIONAL DE PESQUISA DE TRIGO, 17, Passo Fundo, 1994. Resumos. Passo Fundo: EMBRAPA-CNPT, 1994. 20p.

LUSK, J.L.; FOX, J.A.; MCILVAIN, C.L. Consumer acceptance of irradiated meat. Food Technology, v.53, n.3, p.56-59, 1999.

MACARTHUR, L.A.; D'APPOLONIA, B.L. Gamma radiation of wheat I: effects on dough and baking properties. Cereal Chemistry, v.52, p.506-512, 1975.

MACARTHUR, L.A.; D'APPOLONIA, B.L. Gamma radiation of wheat II: effects on dough and baking properties. Cereal Chemistry, n.60, p.456-460, 1983. 
MARATHE, S.A.; MACHAIAH, J.P.; RAO, B.Y.K.; PEDNEKAR, M.D.; RAO, V.S. Extension of shelf-life of whole-wheat flour by gamma radiation. International Journal of Food Science and Technology, v.37 p.163-168, 2002.

MARTINELLI FILHO, A. Microbiologia de alimentos I. Piracicaba: ESALQ/USP, 1987. 248p.

MAYER-MIEBAH, E. Food irradiation: a means of controlling pathogenic microorganisms in food. Lebensmittel Wissenschaft und Techonologie, v.26, n.6, p.493-497, 1993.

MDSNORDION SCIENCE ADVANCED HEALTH. Food irradiation. http://www.mdsnordion.com/documents/Irradiation.pdf (18 Jan. 2003)

MERRIT, C. Jr. Qualitative and quantitative aspects of trace volatile components in irradiated foods and food substances. Radiations Research Review, v.3, p.353,1972.

MILNER, M. Technological effects of gamma-irradiation on wheat. In: INTERNATIONAL CONGRESS OF BIOCHEMISTRY, 5., Moscow, 1961. Proceedings. New York: Pergamon Press, 1961.

MOSS, H.J.; DERERA, N.F.; BALAM, L.N. Effect of pre-harvest rain on germination in the ear and alfa-amylase activity of Australian wheat. Australian Journal of Agriculture Research, v.23, p.769-777, 1992.

NAWAR, W.W. Comparasion of chemical consequences of heat and irradiation treatment of lipids. In: ELIAS, S.; COHEN, A.J. Recent advances in food irradiation. Amsterdan: Elsevier Biomedical Press, 1983. 115p 
NEWSOME, R.L. Perspective on food irradiation. Food Technology. v.41 n.2, p.100-101, 1987.

NG, P.K.W.; BUSHULK, W.; BORSA, J. Effect of gamma ray and high-energy electron irradiations on bread making quality of two Canadian wheat cultivars. Canadian Institute of Food Science and Technology Journal, v.22, p.173-176, 1989.

OLIVER, J.R.; ALLEN, H.M. The prediction of bread banking performance using the farinograph and extensograph. Journal of Cereal Science, v.15, n.1, p.79-89, 1992.

PENCE, J.W. Bread and rools In: TRESSLER, D.K.; VAN ARSDEL, W.B.; COPLEY, M.J. The freezing preservation of foods. Westport: AVI, 1968. p.386-406.

PEREIRA, P.R.V.S. Principais insetos que atacam grãos armazenados. In: SIMPOSIO DE PROTEÇÃO DE GRÃOS ARMAZENADOS, Passo Fundo, 1992. Anais. Passo Fundo: EMBRAPA/CNTP, 1993. p.104-116.

PIZZINATO, A. Qualidade da farinha de trigo: conceitos, fatores determinantes, parâmetros de avaliação e controle. Campinas: ITAL, 1997. 62p.

POMERANZ, Y.; SHOREN, M.; FINNEY, K.F. Natural and modified phospholipids effects on bread quality. Food Technology, v.22, p.897, 1968.

PRATT, D.B. Jr. Criteria of flour quality. In: POMERANZ, Y. Wheat: chemistry and technology. St. Paul: AACC, 1978. p.201-226. 
PREGNOLATTO, W. Normas analíticas do Instituto Adolfo Lutz: métodos químicos e físicos. 3.ed. São Paulo: Instituto Adolfo Lutz, 1985. p.159-164. v.1.

PSZCZOLA, D.E., 20 ways to market the concept of food irradiation. Food Technology, v.51, p.46-48, 1997.

PUZZI, D. Conservação dos grãos armazenados. São Paulo: Ed. Agronômica "Ceres", 1973. 345p.

RAFFI, J.; MIECHEL, J.P.; SAINT-LÉBE, L. Theoretical study of the radiopolymerization of starch. Starch/Staerke, v.32, p.237, 1980.

ROUSHDI, M.; HARRAS, A.; EL-MELIGI, A.; BUSSIM, M.; EL SHELKH, K. Effect of high doses of gamma rays on corn grains. Starch/Staerke, v.37, p.15, 1983.

SABULARSE, V.C.; LIUZZO, J.A.; GRODNER, R.M. Cooking quality of brown rice as influenced by gamma iradiation, variety and storage. Journal of Food Science, v.56, n.1, 1991.

SHIPP, E. Susceptibility of Australian strains of Sithophilus and Tribolium species to gamma radiation. In: CORNWELL, P.B. Entomology of radiation desinfestation of grain. Oxford: Pergamon Press, 1966. p.131141.

SKALA, J.H.; MCCGOWN, E.; WARING, P.P. Wholesomeness of irradiated foods. Journal of Food Protection, v.50, p.150-160,1987. 
SRINIVAS, H.; ANANTHASWAMY, H.N., VAKIL, U.K.; SREENIVASAN, A. Effect of gamma-irradiation on wheat proteins. Journal of Food Science, v.37, p.715-718, 1972.

TAYLOR, R.W.D. Methyl bromide: is there any future for this noteworthy fumigant? Journal of Stored Products Research, v.30, p.253 -260, 1994.

TIPPLES, K.H.; NORRIS, F.W. Some effects of high level gama irradiation on the lipids of wheat. Cereal Chemistry, v.42, p.437, 1965.

THOMAS, M.H. Use of ionizing radiation to preserve food. In: KARMAS, E.; HARRIS, R.S. Nutritional evaluation of food processing. New York: Van Nostrand Reinhold, 1988. p.645-660

TOLLIER, M.T.; GUILBOT, A. Desenvolviment of certain physicochemical properties of the starch granule as a function of irradiated conditions. Starch/Starcrke, v.22, p.296, 1970.

TUNCBILEK, A.S. Susceptibility of the saw-toothed grain beetle, Oryzaephilus surinamensis (L.), to gama radiation. Journal of Stored Products Research, v.33, n.4, p.331-334, 1997.

TUNCBILEK, A.S.; AKIF KANSU, I. The influence of rearing medium no the irradiation sensivity of eggs and larvae of the flour beetle, (Tribolium confusum J. du Val). Journal of Stored Products Research, v.32, n.1, p.1$6,1996$.

URBAIN, W. M. Biological effects of ionizing radiation. In: Food irradiation. Orlando: Academic Press, 1986. p.52-55, 74-78. 
UNIVERSIDADE DE SÃO PAULO. Faculdade de Ciências Farmacêuticas. Tabela brasileira de composição de alimentos. http://wwwfcf.usp.br/tabela/tbcadadoin.php?tbcadado=tbcacoceda. (19 out. 2002)

VAKIL, U.K.; ARAVINDAKSHAN, M.; SRINIVAS, H.; CHAUBAN, P.S.; SREENIVASAN, A. Nutritional and wholesomeness studies with irradiated foods: Indian's program. Vienna: IAEA, 1973. p.673.

WATTERS, F.L. An appraisal of gamma radiation for insect control in cereal foods. Manitoba Entomology, v.2, p.37-45, 1968.

WORLD HEALTH ORGANIZATION - WHO. Safety and nutritional adequacy of irradiated food. Washington, 1994. 161p.

WIENDL, F.M. Alguns usos e efeitos da radiações gama em Zabrotes subfasciatus (Boh, 1833) (Coleoptera, Bruchidae) Piracicaba, 1969. 167p. Tese (Doutorado) - Escola Superior de Agricultura Luiz de Queiroz, Universidade de São Paulo.

YEN, Y.C.; MILNER, M.; WARD, H.T. Treatment of wheat with ionizing radiations. II. effect on respiration and other indices of storage deterioration. Food Technology, v.10, p.411-415, 1956.

ZAIED, S.E.A.F.; ABDEL-HAMID, A.A.; ATTIA E.A. Technological and chemical characters of bread prepared from irradiated wheat flour. Nahrung, v.40, n.1, p.28-31, 1996.

ZELENY, L. Criteria of wheat quality. In: POMERANZ, Y. Wheat: chemistry and technology. 3.ed. St. Paul: AACC, 1978. p.19-45. 